\title{
WestVirginiaUniversity
}

THE RESEARCH REPOSITORY @ WVU

Graduate Theses, Dissertations, and Problem Reports

2008

\section{William Blake's artificial mythology and quotations from world mythos}

Teresa L. Cunningham

West Virginia University

Follow this and additional works at: https://researchrepository.wvu.edu/etd

\section{Recommended Citation}

Cunningham, Teresa L., "William Blake's artificial mythology and quotations from world mythos" (2008). Graduate Theses, Dissertations, and Problem Reports. 806.

https://researchrepository.wvu.edu/etd/806

This Thesis is protected by copyright and/or related rights. It has been brought to you by the The Research Repository @ WVU with permission from the rights-holder(s). You are free to use this Thesis in any way that is permitted by the copyright and related rights legislation that applies to your use. For other uses you must obtain permission from the rights-holder(s) directly, unless additional rights are indicated by a Creative Commons license in the record and/ or on the work itself. This Thesis has been accepted for inclusion in WVU Graduate Theses, Dissertations, and Problem Reports collection by an authorized administrator of The Research Repository @ WVU. For more information, please contact researchrepository@mail.wvu.edu. 
William Blake's Artificial Mythology and Quotations from World Mythos

\author{
Teresa L. Cunningham
}

Thesis submitted to the College of Creative Arts at West Virginia University in partial fulfillment of the requirements for the degree of

\author{
Master of Arts \\ In \\ Art History
}

\author{
Janet Snyder, Ph.D, Chair \\ Rhonda Reymond, Ph.D \\ Kristina Olson, M.A. \\ Department of Art History
}

Morgantown, WV

2008

Keywords: artificial myth, William Blake, Master's thesis, visual art, mythopoeia Copyright 2008 Teresa L. Cunningham 


\begin{abstract}
William Blake's Artificial Mythology and Quotations from World Mythos
\end{abstract}

\title{
Teresa L. Cunningham
}

The central theme of this thesis is the visual analysis of William Blake's art in connection to the available mythological and religious texts by which Blake constructed his own artificial mythology. This analysis will include explorations into Anglo-Saxon, Germanic, Jewish and Hindu myth as well as Christian and mystic texts. The various works or "books" by Blake will be the visual basis, specifically The Marriage of Heaven and Hell (1790), his later "prophetic" work Jerusalem, the Emanation of the Giant Albion (1820) and his last completed work The Illustrations of the Book of Job (1825). This thesis will affirm that Blake was heavily influenced by the various mythological symbolisms around him, which were incorporated and at times quoted, directly in his own work. 


\section{Dedication}

I would like to dedicate this text to my family who are the most important mentors and instructors I could ever wish to have. I would especially like to dedicate this thesis to my

grandmother, Lakie Ocheltree, whose gentle pokes and enthusiastic nudges have been enabled me to come so far in my education and in life.

'It is right it should be so Man was made for Joy \& Woe And when this we rightly know Thro the World we safely go.'

William Blake -excerpt from Auguries of Innocence, 1803 


\section{Acknowledgements}

I would like to acknowledge the following professors and instructors for their guidance and assistance during my studies: Dr. Janet Snyder, Dr. Rhonda Reymond, Kristina Olson, Dr. Robert Hopson, Dr. Gregory Good, and Dr. Joseph Hodge. 


\section{Table of Contents}

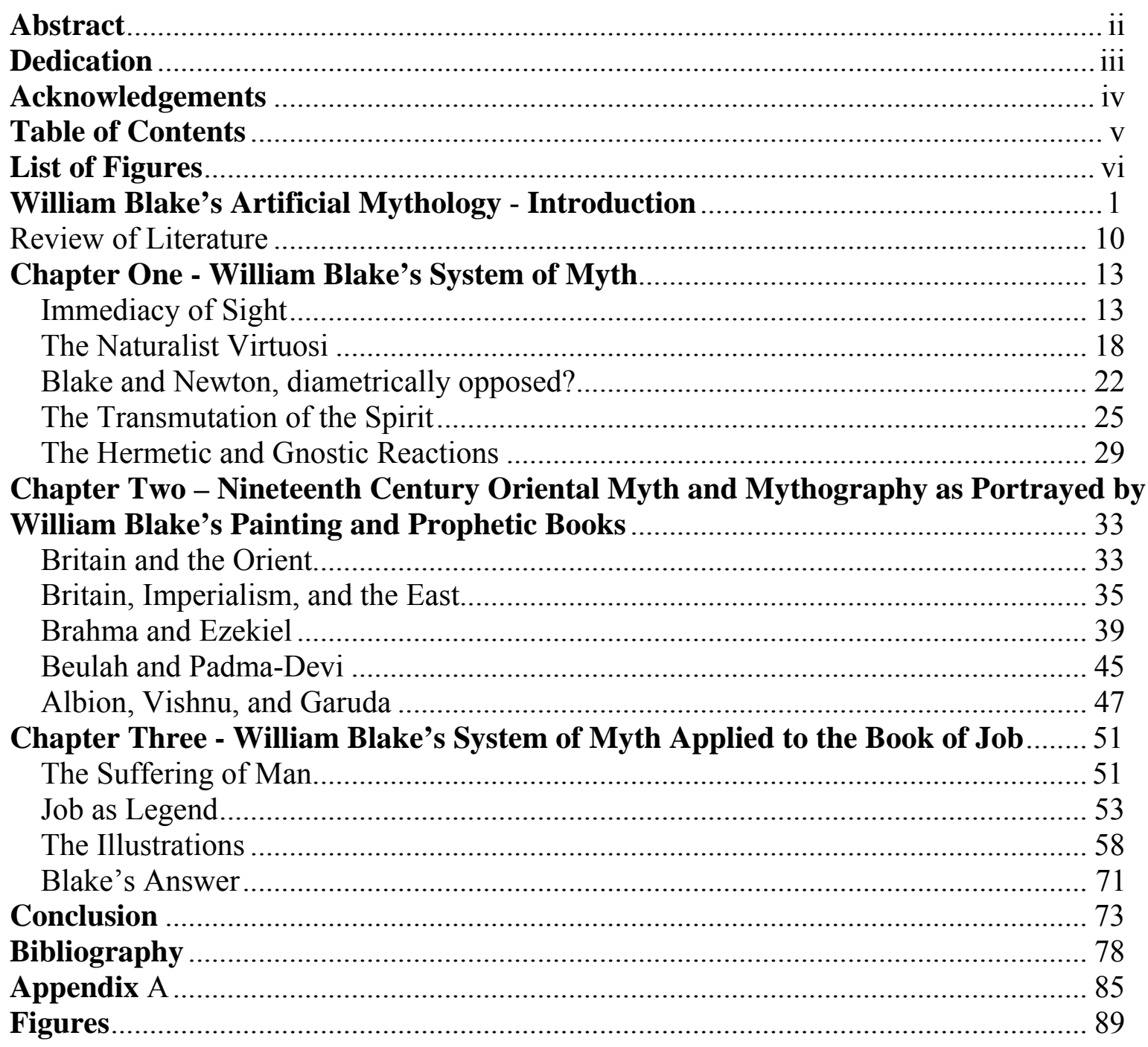




\section{List of Figures}

Figure 1: William Blake, Frontispiece, The Marriage of Heaven and Hell, Copy G, 1790.

Figure 2: William Blake, Frontispiece, Jerusalem, the Emanation of the Giant Albion, 1820

Figure 3: William Blake, Satan Smiting Job with Boils, 1793.

Figure 4: William Blake, King Serbert, 1773.

Figure 5: William Blake, Joseph of Arimathea among the Rock of Albion, 1773/1818.

Figure 6: John Flaxman, Fight over the Body of Patrocles, 1793.

Figure 7: A British Druid, From William Stukeley's Stonehenge: A Temple Restored to the British Druids, Plate I, 1740.

Figure 8: William Blake, Plate 70, Jerusalem, the Emanation of the Giant Albion, 1820.

Figure 9: William Blake, Frontispiece, There is No Natural Religion, copy L, c. 1795.

Figure 10: William Blake, There is No Natural Religion, copy L, object 10 c. 1795.

Figure 11: William Blake, Newton, c. 1795.

Figure 12: William Blake, 'Ancient of Days' from Europe a Prophecy, copy E, object 1, 1794.

Figure 13: William Blake, Plate 1 of The First Book of Urizen; Urizen, 1794.

Figure 14: William Blake, Plate 32, Milton, a Poem, c. 1804-1811.

Figure 15: William Blake, Plate 6, Jerusalem, the Emanation of the Giant Albion, Los, 1820.

Figure 16: William Blake, Plate 92, Jerusalem, the Emanation of the Giant Albion, Luvah, 1820.

Figure 17: William Blake, Plate 87, Jerusalem, the Emanation of the Giant Albion, Enitharmon, 1820.

Figure 18: William Blake, The Book of Ahania, “Ahania and Urizen,” 1795.

Figure 19: William Blake, Plate 12, America, a Prophecy, Orc, 1793. 
Figure 20: John Flaxman, "Woman in Indian Costume."

Figure 21: William Blake, Frontispiece, All Religions Are One, c. 1788.

Figure 22: Moses Haughton, Brahma, Plate 3 of The Hindu Pantheon.

Figure 23: Moses Haughton, Brahma, Plate 4 of The Hindu Pantheon.

Figure 24: William Blake, Ezekiel's Vision, 1803-1805.

Figure 25: William Blake, Plate 53 of Jerusalem, the Emanation of the Giant Albion, Jerusalem, 1820.

Figure 26: Moses Haughton, Padma-Devi, from The Hindu Pantheon.

Figure 27: William Blake, Detail of Plate 14 of Jerusalem, the Emanation of the Giant Albion, Albion and Vala, 1820.

Figure 28: Panel of Vishnu and Brahma from the Vishnu Temple in Deogarh, Gupta Architecture, 300-600 CE.

Figure 29: William Blake, Detail of Plate 78 of Jerusalem, the Emanation of the Giant Albion, 1820 .

Figure 30: Moses Haughton, Garuda with Vishnu and Consort, from The Hindu Pantheon.

Figure 31: William Blake, The Marriage of Heaven and Hell, plate 5, 1790.

Figure 32: William Blake, Elohim Creating Adam, 1795.

Figure 33: William Blake, The Illustrations of the Book of Job, Frontispiece, 1825.

Figure 34: William Blake, The Illustrations of the Book of Job, “Job and his Family," 1825.

Figure 35: William Blake, The Illustrations of the Book of Job, "Satan before the Throne of God," 1825.

Figure 36: William Blake, The Illustrations of the Book of Job, "The Destruction of Job's Sons," 1825.

Figure 37: William Blake, The Illustrations of the Book of Job, "The Messengers tell Job of the Misfortunes that have Befallen him," 1825.

Figure 38: William Blake, The Illustrations of the Book of Job, "Satan going forth from the Presence of the Lord," 1825. 
Figure 39: William Blake, The Illustrations of the Book of Job, "Satan smiting Job with Boils," 1825.

Figure 40: William Blake, The Illustrations of the Book of Job, “Job's Comforters," 1825.

Figure 41: William Blake, The Illustrations of the Book of Job, “Job’s Despair,” 1825.

Figure 42: William Blake, The Illustrations of the Book of Job, “The Vision of Eliphaz,” 1825.

Figure 43: William Blake, The Illustrations of the Book of Job, "Job rebuked by his Friends," 1825.

Figure 44: William Blake, Frontispiece, America, a Prophecy, 1793.

Figure 45: William Blake, The Illustrations of the Book of Job, “Job’s Evil Dreams,” 1825.

Figure 46: William Blake, The Illustrations of the Book of Job, “The Wrath of Elihu," 1825.

Figure 47: William Blake, The Illustrations of the Book of Job, "The Lord answering Job out of the Whirlwind," 1825.

Figure 48: William Blake, The Illustrations of the Book of Job, "The Lord answering Job out of the Whirlwind," print, 1825.

Figure 49: William Blake, The Illustrations of the Book of Job, "The Creation," 1825.

Figure 50: William Blake, The Illustrations of the Book of Job, "Behemoth and Leviathan," 1825.

Figure 51: William Blake, The Illustrations of the Book of Job, “The Fall of Satan,” 1825.

Figure 52: William Blake, The Illustrations of the Book of Job, "The Vision of God," 1825.

Figure 53: William Blake, The Illustrations of the Book of Job, "The Vision of God," print, 1825.

Figure 54: William Blake, The Illustrations of the Book of Job, “Job’s Sacrifice,” 1825.

Figure 55: William Blake, The Illustrations of the Book of Job, "Job Accepting Charity," 1825.

Figure 56: William Blake, The Illustrations of the Book of Job, "Job and his Daughters," 1825.

Figure 57: William Blake, The Illustrations of the Book of Job, "Job and his Daughters," print, 1825. 
Figure 58: William Blake, The Illustrations of the Book of Job, "Job and his Wife restored to Prosperity," 1825.

Figure 59: Dante Gabriel Rossetti, “A Sonnet' from the House of Life, “Anima,” 1880. 


\title{
William Blake's Artificial Mythology and Quotations from World Mythos
}

\author{
"I must Create a System or be enslav'd by another Man's \\ I will not Reason \& Compare: my business is to Create." 1
}

\section{Introduction}

Creation demands a system, whether it is the creation of a utilitarian object like a piece of pottery, or creating something as abstract as a law. ${ }^{2}$ In this world, there exist systems of government, religion, social decorum, philosophy, literature, art, and various other sorts of matters that involve mankind. One system that has existed long before that of government or religion is the system of mythology. ${ }^{3}$ Every culture has its unique history as well as its own mythology. Mythology has permeated every aspect of

\footnotetext{
${ }^{1}$ An excerpt from Jerusalem the Emanation of the Giant Albion, plate 10, lines 21 through 22.

2 The statement "Creation demands a system" is an exercise in logic. Beginning with the JudeoChristian notion of God's creation of light and dark, earth from sea in Genesis 1:1, every form of creation demands a system or methodology to result in a final product or creation. A system is defined, generally, as an assemblage or combination of elements that comprise a unitary whole. As in the case of concepts of government, religion, philosophy, and mythology, a system is defined as an ordered and comprehensive assemblage of facts, principles, and doctrines.

${ }^{3}$ Mythology, in terms of definition, is a set of stories, traditions or beliefs that can be associated with a particular cultural group and its history either arising naturally through folktales, or fostered deliberately by a state religious organization or government.
} 
mankind's culture, perhaps most notably in the visual manifestation of art. From ancient religious artifacts such as a relief of Vishnu at the Vishnu Temple at Deogarh to Nineteenth-Century paintings of Venus by Ingres, mythology has a visual manifestation.

However, the creative system of myth has grown beyond including the tales of religions or historical events, ancient and contemporary. Artificial mythology, instead of being derived from oral, historical, or literary traditions, was a new form of mythology. It follows the same system as world mythology, but differs in the sense that it is created either by an individual, or by a group of individuals who purposely create a system from original ideas and not purely from cultural or religious references. Today, artificial mythology is generally seen in context of science fiction or fantasy genres of literature or motion pictures, but the roots each back a century before writers such as J.R.R. Tolkien (1892-1973) and C.S. Lewis (1898-1963). Both men were great scholars and both created artificial mythologies to systematize the created worlds of Middle-earth and Narnia. The precursor to such popular myths as Tolkien's Middle-earth and Lewis' Narnia are the myths of Albion (Fig. 27), Urizen (Fig. 13), and Los (Fig. 15) created by the British painter-poet William Blake (1757-1827).

William Blake's system of artificial mythology began to appear as early as 1790 in Blake's The Marriage of Heaven and Hell (Fig. 1) and continued to grow in depth and complexity through his later original work Jerusalem, the Emanation of the Giant Albion (Fig. 2) in $1820 .{ }^{4}$ Blake's poetry and illustrations bolstered his system of artificial mythology. It is through the visual vocabulary that Blake's artificial mythology can be analyzed in terms of underlying sources and traditional mythologies that were used by

\footnotetext{
${ }^{4}$ The frontispiece and title page to the aforementioned works, both works will be analyzed and referenced throughout this text.
} 
Blake in his work. Borrowing from his native Britain, Blake incorporated Anglo-Saxon myth, as well as the myth of ancient Germanic cultures. Oriental mythology was also included in Blake's worlds. To further add to his artificial mythology, Blake looked to the Bible, hoping to ground his pantheon of gods and characters in the holiest text in his own life. The central theme of this thesis is the visual analysis of William Blake's art in connection with the available mythological and religious texts by which Blake constructed his own artificial mythology. This thesis will prove that Blake was heavily influenced by the various mythological symbolisms around him, which were incorporated, and, at times, quoted directly in his own work.

To begin to understand Blake's system of myth, one must understand some aspects of the man himself. Social class and religious belief are two important elements to be taken into consideration in Blake's corpus of work. William Blake was born to James Blake and Catherine Hermitage in 1757 and was raised within the socio-economic middle class, or "Middling Sort" in London. ${ }^{5}$ Blake's father, and later his older brother, were hosiers, while Blake was never formally trained in any trade or skill. In fact, Blake was never formally taught at any school or academy. Much of his knowledge of philosophy, theology, Latin, and Hebrew came from study later in life. ${ }^{6}$ The reason that a child of a middle class family was not forced into school had much to do with the religious viewpoints of the Blake family. Religious belief in England has been an issue of much strife and contention since the Seventeenth Century with dissenting Protestant groups in opposition to the State Church and Calvinist reforms under the rule of Charles I (1600-1649). The English Revolutions introduced groups called Levellers, Diggers,

\footnotetext{
${ }^{5}$ The "Middling Sort" was a term used often during the Eighteenth and Nineteenth Centuries to define the growing Middle Class of Britain, which was a class of merchants and other tradesmen.

${ }_{6}^{6}$ Peter Ackroyd, Blake, a biography, (New York: Alfred A. Knopf Publishers, 1996), 17.
} 
Seekers, and Ranters, all of who held an opinion as to how England should conduct itself politically and in matters of faith. The entire Seventeenth Century was a time of great tumult in England in every aspect of life that affected the lower classes to aristocracy. By the Eighteenth Century and into the Nineteenth Century, religious belief had become a matter of individual prerogative, as the liberty of conscience won over the monarchical and governmental institution of a single State Church and strictly Anglican doctrine. By the time William Blake reached maturity, English Dissenters consisted of the Muggletonians and Taskites, which believed to some degree that man must build God's kingdom on earth and live in freedom and equality. ${ }^{7}$

The Blake family was of the dissenting sects although it is unclear to which sect the Blakes belonged. ${ }^{8}$ Having radical or liberal religious beliefs, the need to send a young William Blake to the local Dissenting academies was of no great importance to the Blake family. William Blake was free to express his dislike and anxiety for schools and education when later in life he once explained to a persistent enquirer about his lack of formal education, "There is no use in education, I hold it wrong. It is the great Sin. It is eating of the tree of Knowledge of Good and Evil."9

However, not all knowledge was wrong to Blake, and the greatest textbook in his life was the Bible. Within a Dissenting household, it is only natural that the Bible is so important to each member of the family as it was the ultimate book of spiritual law. To William Blake, the Bible would become a source of meditation and interpretation. From his earliest to his latest work, biblical motifs and commentary runs throughout his images

\footnotetext{
${ }^{7}$ Peter Marshall, William Blake: Visionary Anarchist (London: Freedom Press, 1988), 19. Muggletonians specifically believed in the Second Coming of Christ and the coming of the Millennium as well as the mortality of the soul.

${ }^{8}$ Peter Ackroyd, Blake, a biography, 18.

${ }^{9}$ Ibid, 23.
} 
and poetic verses. However, and perhaps due to his Dissenter roots, Blake's work and love of the spiritual was slightly skewed from the simple and predominant use of the Old Testament which was rich with imagery Blake could assimilate.

William Blake, like many Englishmen, considered himself a Christian, but never attended church services regularly. However, Blake's beliefs, again like many Englishmen, were of the Protestant persuasion. Blake was a "follower of Christ," and with this in mind, sought out his own spiritual truths. ${ }^{10}$ Like any good Dissenter, Blake had embarked on a journey to "seek" out the will of God, and to throw off the yoke of ritual, which was so prominent in the Anglican Church, and even more prominent in the reviled Catholic Church in England. ${ }^{11}$

Figures such as Gerrard Winstanley (1609-1676), a dissenting Digger, and more importantly, the Swedish mystic and writer Emanuel Swedenborg (1688-1772) influenced Blake in ultimately shaping his own understanding of his world and personal doctrines. Before Blake could set out to seek his personal Christ, Blake's spiritual quest was to be initiated in part by Emanuel Swedenborg. Emanuel Swedenborg and his influence on Blake's early life has become a contested issue in recent scholarship. Some scholars, particularly those who have studied Swedenborg, have attributed Blake's understanding of Swedenborg and the strange anecdotes of Blake's early life in connection to Swedenborgianism as legend. ${ }^{12}$ However, early Blakean biographers have

\footnotetext{
${ }^{10}$ Kathleen Raine, The Human Face of God: William Blake and the Book of Job, 10.

${ }^{11}$ The reference of "seeking" is the basic idea behind the dissenting sect of the Seekers who were anticlerical and believed all organized churches to be corrupt. Seekers shunned creeds and were not organized into particular denominations; by this, Seekers are considered to be the forerunners of Quakers.

${ }^{12}$ Morton D. Paley, "'A New Heaven is Begun': Blake and Swedenborgianism," in Blake and Swedenborg: Opposition is True Friendship, an anthology, the sources of William Blake's art in the writings of Emanuel Swedenborg, edited by Harvey F. Bellin and Darrell Ruhl (New York: Swedenborg Foundation, Inc., 1985), 15. Paley mentions Erdman and various journals stating Blake and his early
} 
situated Blake and Swedenborg in close relation doctrinally. The premise of Swedenborg's teachings echo back to early Christian Gnosticism, yet his teachings were not as elitist and extreme as the heresies that would result from the Gnostic writings. ${ }^{13}$

Swedenborg, in his books, claims to interpret the arbitrary symbols in which, as Scripture itself informs us, all who were not in the secret must expect to find the Word hopelessly and purposely hidden. Swedenborg believed that "seeing we might see and not perceive, and hearing we might hear and not understand, lest we should see with our eyes and hear with our ears, and understand with our hearts, and be converted and healed."14 At any rate, scholars do know that William Blake had read Swedenborg's work and wrote notes in a personal copy of Divine Providence (1764) and reacted by producing a visual and poetic satire called The Marriage of Heaven and Hell (1790, Fig. 1).

Mysticism, a belief of oneness with God transcending ordinary understanding, is integral to the system of Blake's mythology. Through the vehicle of mysticism, Blake arrived at a vision and a prophecy. Indeed, Blake's "prophetic" books are fraught with riddles and secret knowledge. In Jerusalem, the Emanation of the Giant Albion (1820), Blake's vision and mythology are fully expressed. But how does one interpret the vision of another man? Blake defines "vision" as a fourfold concept, so abstract and so complex that it can only be explained in Blake's own words:

Now I a fourfold vision see, And a fourfold vision is given to me; 'Tis fourfold in my supreme delight

connection with Swedenborgianism as myth. However, early biographers such as Alexander Gilchrist and Crabb Robinson have connected Blake to Swedenborg.

${ }^{13}$ The Gnostic Heresy was one of the early Church heresies of the Second and Third Centuries identified to be a heresy adhering to the concept of a 'secret knowledge' to salvation. The heresy challenged the legitimacy of the synoptic gospels now considered canon, thus certain apocryphal gospels survived.

${ }^{14}$ Edwin J. Ellis, The Real Blake: A Portrait Biography (New York: McClure, Phillips and Co., 1907), 25. 
And threefold in soft Beulah's night

And twofold Always. May God us keep

From Single Vision \& Newton's Sleep! ${ }^{15}$

The fourfold vision, mysticism, Swedenborg, The Marriage of Heaven and Hell, and the journey toward citing world mythology in Blake's artificial construction will be the subject of subsequent chapters entitled: 'Chapter One - Blake's System of Myth,' 'Chapter Two - Nineteenth-Century Oriental Myth as Portrayed by William Blake's Painting and Prophetic Books,' and finally, 'Chapter Three - William Blake's System of Myth Applied to the Book of Job.'

Blake's mythology extended beyond that of biblical lore, Christian mysticism, and the dissenting histories and folktales of his homeland. Beginning in the Seventeenth Century, England was expanding its rule to areas of the world then accessible by fleets of modern trading and naval vessels. With the establishment of the East India Company, England expanded its Empire, and thus gave British artists a new realm to explore and eventually visually represent in paintings or in prints. Until the 1770s, all the British people knew of India was from fantastical works of art and tales from traders returning from the East. One such example of British understanding of Indian culture was from Edward Moor's The Hindu Pantheon, a work discussed in depth in Chapter Two.

However, after the 1770s, artists began visiting the mysterious land of India and observed the land through British eyes. The first works of art were commissioned from British residents living in India, but the demand slowly changed from family portraits to that of Indian subjects in light of growing interest by the British people for accurate descriptions of the far-away-land and its people. In France, the interest in the "other" had

\footnotetext{
${ }^{15}$ Mark Schorer, William Blake: the Politics of Vision, 5.
} 
begun with France's expeditions into Northern Africa and the Middle East, but for England, the "other" was even farther away, and very different from the Arab world. The second chapter will deal with Blake's assimilation of foreign mythology and its incorporation into Blake's system. Attention will be paid to connections between the availability of Hindu mythologies and the allusions drawn in Blake's artistic work from Eastern influences seen particularly in Jerusalem, the Emanation of the Giant Albion.

With the construction of his artificial system, Blake's later life and art-postJerusalem and after 1820 — dealt with illustrating several texts such as Dante's Inferno and The Book of Job from the Old Testament. The Illustrations of the Book of Job (1825) was of particular interest to Blake who concentrated much of his personal biblical study and the execution of illustrations in his early career to Old Testament subjects. Blake's fascination with the Old Testament figure of Job was manifested as early as 1793. Blake produced a large engraving of Job, as well as a painting of Satan smiting Job with boils (Fig. 3), which would be later reused in the Illustrations of the Book of Job. ${ }^{16}$ Although Blake was fascinated with Job, he was not satisfied with the Biblical portrayal of the character. Therefore, in his rendition of The Illustrations of the Book of Job, Blake incorporated his own system of mythology to fill in the gaps that the Old Testament writers left open for elaboration. The question of why man suffers is the subject of the Book of Job, and Blake set out to complete the book's ultimate message by using of his own artificial myth. The final chapter of this thesis will explore how Blake applied his system to the age-old tale of Job and Job's natural fit into that system.

\footnotetext{
${ }^{16}$ The Philadelphia Museum of Art, William Blake 1751-1827. A descriptive catalogue of an exhibition of the works of William Blake selected from collection in the United States (Philadelphia, PA: The Philadelphia Museum of Art, 1939), 86.
} 
Ultimately, this thesis will deal with only a part of the basis for Blake's system, a new visual analysis as compared to a textual analysis that has already been so well documented by other Blake scholars. The unique style of Blake's visual work is often downplayed in light of his lyrical and narrative poetry. While Blake's poetry can be comprehended, the visual counterpart is at times confusing and enigmatic. All the same, the text and image are inexorably linked as creations and manifestations of Blake's overall system. This thesis will analyze a selection of Blake's work for visual phrases that have been appropriated from various cultures. Blake's work, both poetic and artistic, is a testament to his understanding of the world's cultures and religions. Blake was not constrained by his imagination as to how the world's system of existence functioned. By understanding Blake's worldview and how Blake incorporated world mythology into his system, readers will gain a greater understanding of Blake's personal system of artificial mythology. 


\section{$\underline{\text { Review of Literature }}$}

William Blake, English painter-poet, has been the subject of many scholarly works since the end of the Nineteenth Century. Not until the Twentieth Century was the concept of artificial mythology or mythopoeia used to describe the context of Blake's Prophetic works. ${ }^{17}$ Many scholars have written extensively on Blake's Prophetic poetry and system of myth in literary critique. Mark Schorer's William Blake: The Politics of Vision includes a chapter entitled "The Necessity of Myth" outlining Blake's rejection of Classical Mythology and the beginnings of Blake's personal system of myth. ${ }^{18}$ Thomas J. J. Altizer in The New Apocalypse: the Radical Christian Vision of William Blake notes in the book's thesis that Blake was the most original prophet and seer in the history of Christendom. In creating a completely new form of vision embodying modern radical and spiritual expression of Christianity, Blake's Prophetic Books demands a new form of theological understanding. ${ }^{19}$

Considering religion and myth, scholars have written many analyses of Blake's poetic works. However, Blake was not merely a poet, and many of his original works incorporated image and text to form a complete and unique work. Visual analysis of Blake's artistic style has been documented by such scholars as David Bindman in Blake as an Artist, Anthony Blunt's The Art of William Blake, and Morris Eaves' William

\footnotetext{
${ }^{17}$ These works include America a Prophecy (1793), The First Book of Urizen (1794), and Jerusalem, the Emanation of the Giant Albion (1820).

${ }^{18}$ Mark Schorer, William Blake: the Politics of Vision (New York: Vintage Books, 1959).

${ }^{19}$ Thomas J. J. Altizer, The New Apocalypse: the radical Christian vision of William Blake (Aurora, CO: The Davies Group, Publishers, 1967).
} 
Blake's Theory of Art, among others. ${ }^{20}$ The complexity of Blake's artwork, combined with his rich poetry, has made Blake a rich subject for literary scholars and art historians. Blake's artificial mythology and unique Christian beliefs have invited theologians and philosophers to study him as well.

This thesis aims to analyze Blake's artificial mythology, considering the visual sources of Blake's system. This analysis takes into consideration Blake's life, his biography, his personal belief, and of views of the time in which he lived in Britain. The immediate influences will then be examined in the light outside influences of other artists and imported mythologies. One such imported mythology has been thoroughly studied in David Weir's Brahma in the West: William Blake and the Oriental Renaissance. ${ }^{21}$ The importance of Hindu myth to Blake's system is used in this thesis to further substantiate Blake's artificial mythology. The last chapter of this thesis analyzes Blake's use of his artificial myth as applied to the Book of Job in the Old Testament. Artificial myth was used by Blake to resolve a fundamental question posed by the Book of Job. Much scholarship has been written about Blake's last complete work, such as Malcolm Cormack's William Blake: Illustrations to the Book of Job and Kathleen Raine's The Human Face of God: William Blake and the Book of Job. ${ }^{22}$ However, in terms of strictly art historical scholarship on William Blake, few comprehensive works take into consideration the myriad sources of visual inspiration in Blake's work. From Britannic, Hindu, Germanic, Egyptian, and Kabalistic myth, William Blake uses visual quotations

\footnotetext{
${ }^{20}$ David Bindman, Blake as an Artist (Oxford: Phiadon Press Ltd., 1977). Anthony Blunt, The Art of William Blake (Morningside Heights, NY: Columbia University Press, 1959). Morris Eaves, William Blake's Theory of Art (Princeton, NJ: Princeton University Press, 1982).

${ }^{21}$ David Weir, Brahma in the West: William Blake and the Oriental Renaissance (Albany, NY: State University of New York Press, 2003).

${ }^{22}$ Malcolm Cormack, William Blake: Illustrations to the Book of Job (Richmond, VA: Virginia Museum of Fine Art, 1997). Kathleen Raine, The Human Face of God: William Blake and the Book of Job (New York, NY: Thames and Hudson, 1982).
} 
to compose his artificial mythology. This thesis, William Blake's Artificial Mythology and Quotations from World Mythos, is a new investigation into the various sources, philosophical and visual, that compose the basic tenants of William Blake's artificial mythology. 


\title{
Chapter One - William Blake’s System of Myth
}

\author{
“...lord of thyself, thou then art lord of all." ${ }^{23}$
}

\section{Immediacy of Sight}

On August 4, 1772, William Blake began his apprenticeship under the engraver James Basire (1730-1802). This apprenticeship was a term of seven years and in this time; Blake's natural talents were honed. During this kind but arduous tenure, Blake copied the medieval monuments of London. Perhaps the most important of these images were the tombs, mosaics, and wall paintings at Westminster Abbey. One such example of Blake's early work being that of a 1775 image of the founder of the Abbey, Serbert, in 616 CE (Fig. 4). In this example, a viewer can see Blake could execute work in a formal,

\footnotetext{
${ }^{23}$ Phrase from an unfinished poetical sketch, the first identifying line being "[T]hen She bore pale desire," included in Blake's Poetical Sketches, published in 1783.
} 
academic style. Nevertheless, during his apprenticeship, Blake began perfecting his own style. It was also a time in Blake's life where he began to consider the immediate systems of mythology around him. This chapter will discuss the early influences of myth on the formation of Blake's system, as well as the impact and assimilation of Emanuel Swedenborg (1688-1772) and briefly, Jakob Bohme's (1575-1624) system of mysticism. This chapter will establish the foundation of Blake's system which would culminate in perhaps his greatest and most complex artistic work, Jerusalem, the Emanation of the Giant Albion (1820). To begin to understand the basis of Blake's system, one must start at the beginning of Blake's artistic career.

While Blake was studying and engraving the tombs and walls of Westminster Abbey, he also developed a sense of wonderment at the growing collection of mythologies of Britain. Peter Ackroyd, a modern Blake biographer, tells us:

Blake's reverence for antiquity had mythological as well as religious connotations, however, and like many brilliant autodidacts, he tended to favor recondite or esoteric systems of knowledge." Also "all his life Blake was entranced and persuaded by the idea of a deeply spiritual past, and he continually alluded to the possibility of ancient lore and arcane myths that could be employed to reveal previously hidden truths. It is part of his reverence for the mysteries of Gothic art that Westminster Abbey had instilled in him, but it is also connected to less distinct ideas; he became heavily influenced by beliefs in the lost continent of Atlantis, of which the British Isles were the only remnant, and in the existence of Druid priests or Welsh magicians. There were also very much the preoccupations of his period, when comparative mythology was often aligned with the wilder speculations of various prophetic sects; Blake's interest was, if idiosyncratic, at least comprehensive. ${ }^{24}$

The best example, and incidentally Blake's first original engraving while working under Basire, was that of Joseph of Arimathea among the Rocks of Albion (Fig. 5), first executed in 1773. This is the legendary figure of the man who had fled from Judea to England, carrying the blood of Christ in the Holy Grail, an object that figures greatly in

\footnotetext{
${ }^{24}$ Peter Ackroyd, Blake, a biography, 58-59.
} 
British legend. Joseph of Arimathea, in legend, was the first to bring the Gospel to Albion, or England, and established the first Christian church at Glastonbury. ${ }^{25}$ Blake's engraving underwent a change later in 1810 and he included the inscription:

Joseph of Arimathea among The Rock of Albion. This One of the Gothic Artist who Built the Cathedrals in what we call the Dark Ages, Wandering about in sheep skins \& goat skins, of whom the World was not worthy; such were the Christians in all Ages. Michael Angelo Pinxit. Engraved by W. Blake 1773 from an old Italian Drawing. ${ }^{26}$

During Blake's lifetime, probably none among Blake's varied friends understood the scope and depth of his artistic style like John Flaxman. ${ }^{27}$ Both artists used a Mannerist style in depicting figures, relying on the use of the Neo-Classicist line such as Flaxman's Fight over the Body of Patrocles from 1793 (Fig. 6). The proportions and contortions of the bodies utilized the dramatic Mannerist effect making Flaxman's and in particular Blake's work unique. ${ }^{28}$ Influenced produced by engravings of Raphael, Durer, and Michelangelo, Blake incorporated a personal stylization to make the work his own such as that in Joseph of Arimathea among the Rocks of Albion (Fig. 5). Blake's method of drawing the human figure is highly schematic, and was based on personal experience and imagination rather than observation or study. ${ }^{29}$ However, it was not just the use of strong line, and intense gesticulations of the human form that distinguished Blake's work as unique in his time.

\footnotetext{
25 Ibid, 47.

${ }^{26}$ S. Foster Damon, A Blake Dictionary, the ideas and symbols of William Blake (Hanover, NH: University Press of New England, 1988), 225.

${ }^{27}$ Kathleen Raine, The Human Face of God: William Blake and the Book of Job, 9.

28 Anthony Hunt, The Art of William Blake, 85.

${ }^{29}$ Edward Lucie-Smith, Symbolist Art (London: Thames and Hudson Ltd., 1972), 34. It has also been suggested by Joseph Burke in his article "The Eidetic and the Borrowed Image: An Interpretation of Blake's Theory and Practice of Art." In The Visionary Hand: Essays for the study of William Blake's art and aesthetics, edited by Robert N. Essick (Los Angeles: Hennessey \& Ingalls, Inc., 1973), that Blake extrapolated some of his style and imagery from engravings available to Blake during his lifetime. Such engravings vary from Western subjects to Oriental subjects.
} 
The image of Joseph of Arimathea, bearded and bedraggled, was taken, in part from William Stukeley's (1687-1765) Stonehenge: A Temple Restored to the British Druids (1740, Fig. 7), one of many British mythic anthologies Blake was familiar with during his apprenticeship. ${ }^{30}$ However, the Druids were threatened by the legendary arrival of Joseph of Arimathea. The Druids were priests and judges in Britain who offered human sacrifices, held oaks to be sacred, and supposedly built Stonehenge among other massive stone configurations dotting the landscape of the Isles. By Blake's time, the Druids had been romanticized, and their significance conflated into being not that of pagan leaders, but something that would suit the Christian nation of Britain.

William Stukeley considered Druids to be Phoenicians, who had preserved a pure form of the religion of Abraham, while Francis Wilford, a British Orientalist, actually placed the Biblical patriarchs in Britain. Wilford was about to declare Britain as the seat of Biblical history when in 1805 , he admitted his work and study was the product of forgery and misinformation. Blake borrowed from Wilford's theory, considering the Druids to be the descendants of the "Patriarchal Religion." In his later work, Blake represented the Druids as a negative aspect of Albion, symbolizing Deism, the religion of Natural Man, the savage that still existed in Blake's perspective. ${ }^{31}$ Blake employed Druidic architecture several times in Jerusalem, the Emanation of the Giant Albion (Fig. 8) and in The Illustrations to the Book of Job (Fig. 38) to represent the evil of stagnant and unimaginative religion.

Between the years of Joseph of Arimathea in 1773 and the death of Blake's brother Robert in 1787, Blake worked alternately between Basire and the Royal Academy

\footnotetext{
${ }^{30}$ Stukeley's text can be found online: http://www.sacred-texts.com/neu/eng/str/index.htm. Peter Ackroyd, Blake, a biography, 49.

${ }^{31}$ S. Foster Damon, A Blake Dictionary, the ideas and symbols of William Blake, 108-109.
} 
where he developed a dislike for and scorned the teachings of Sir Joshua Reynolds (17231792), who was the Academy's President at the time. In the margins of a copy of Reynold's Discourses of Art, Blake pencil in: "This man was hired to Depress Art.",32 Blake disliked having to study and draw from Greek and Roman artifacts and the styles of the art of antiquity. He rejected Greek and Roman mythology. Blake was aware of the impact of Greek and Roman art in France as well as the influence it had in the décor of the Seventeenth and Eighteenth Centuries. He found this system of myth to be "Bloated Gods, Mercury, Juno, Venus \& the rattle traps of Mythology \& the lumber of an awkward French Palace are thrown together around Clumsy \& Ricketty Princes \& Princesses higgledy piggledy." ${ }^{33}$ Greek and Roman myth was to be a meaningless system to Blake, as stagnant as patriarchic religion.

In 1782, Blake married Catherine Boucher, a woman who would work with Blake to the end of his life, encouraging his imagination and promoting his art. The other important figure in Blake's life was his younger brother Robert who helped his older brother manufacture and sell of prints. Robert had been working under his brother when at the age of nineteen Robert fell ill and died, presumably from consumption. This event is significant for two reasons: 1) William Blake experienced a vision, one of many in his life, of his brother Robert's soul leaving his earthly body and his spirit would return to William Blake through the years in more visions. And 2) after several days of sleep and grief, William Blake took an unnatural and sudden interest in studying the writings of Emanuel Swedenborg. ${ }^{34}$

\footnotetext{
${ }^{32}$ Brian and Judy Dobbs, Dante Gabriel Rossetti: An Alien Victorian (London: Macdonald and Jane's Publishers, Ltd., 1977), 34.

${ }^{33}$ Mark Schorer, William Blake: the Politics of Vision, 31.

${ }^{34}$ Peter Ackroyd, Blake, a biography, 100-101.
} 
However, Blake's initial forays into constructing his own system of myth were not merely a rejection of the new trend in mythography, or the study of Greek and Roman myth that was so popular with the British Academy. Many factors, besides the myths of the Britons and his personal loss, came into play as William Blake created his system. Blake needed his system to consider every aspect of the human being, especially the matter of the human soul.

\section{The Naturalist Virtuosi}

The Enlightenment of the Eighteenth Century brought about the rise of many of the academic conformities known to the modern world. However, during the Seventeenth and into the Eighteenth Centuries, one newly defined convention arose to propel humankind into a modern age: science. In England, many groups of men began to see a conflict between this 'new' science and the Christian religion. To reconcile science and faith, in a manner of speaking, these men began calling their faith and their science the 'Rational Foundations,' or more subtly: Natural Science.

In the Seventeenth Century, England was experiencing turbulent times as the government was evolving from a system of the divine right of monarchy to one in which a Protectorate was instituted under Oliver Cromwell (1599-1658). Eventually a limited 
monarchy was installed with the slow beginning of the end of the 'Old Corruption' or the corruption of Parliament. Philosophy and religion also changed due to the freedoms of the institutions in England. With the treatises of John Locke (1632-1704) and Thomas Hobbes (1588-1679) and the Religious Dissenters, the concept of the freedom of speech and religion became dear to the hearts and minds of the English people. In science and religion, the shift from Augustine's Neo-Platonism to Aristotelianism went further to create a new mechanical — and less superstitious - conception of the universe with 'natural science.' At last, it was believed that religion and science could exist together in the realm of the same thought. These scientists of the Seventeenth Century were called 'virtuosi,' or men of outstanding technical ability, and they considered themselves the answer to the conflict between science and religion. These men included Isaac Newton (1643-1728), a legendary figure in English history, the father of modern physics. Other virtuosi were John Ray (1627-1705), Nehemiah Grew (1641-1712), and Robert Boyle (1627-1691). Each had different areas of interest, but together they solidified the tenets of natural science into the methods of experimentation and theory in their day. Through their discoveries, the virtuosi formulated a mechanical, geometric, and quantifiable universe, and in Calvinist tradition saw God as the Great Watchmaker, Great Engineer, or Great Architect. However, the concept of a mechanical universe threatened the primacy of God in several ways. The virtuosi, in order to keep their faiths from falling victim to their science, used Christianity as their rule and measure with the Bible as the ultimate proof of their natural philosophies. Using the Bible, particularly the Old Testament, the virtuosi declared three points of the truth of their natural philosophy: 1) the Creation, which natural science does not contradict; 2) the Deluge and its physical causes, which 
can be explained via natural science; and 3) the final dissolution of the world by means of natural causes. ${ }^{35}$

To protect the existence and wisdom of God, the virtuosi claimed that the evidence of God can be seen in his creatures and in every element of nature from the heavens to the parts of insects, all fitting into a universal order. This universal order was called teleology. For the virtuosi, the design of nature reveals a designer, what is in the Twenty First Century called 'intelligent design.' For the virtuosi, teleology was the explanation used defensively against atheism and paganism. However, questions arose concerning providence, free will, and the spirit. How could the virtuosi, who saw God as the Great Architect, take into consideration the existence of miracles and the mysteries with their rule and measure the Bible? By questioning the existence of miracles, the virtuosi saw that they were nullifying their own defenses against atheism and agnosticism. "One of the reasons behind the virtuosi's ventures into natural religion to refute atheism was the desire to preserve their own reputations for orthodoxy."36

The virtuosi countered the mystery of miracles by considering that God would intervene only at important times. Nehemiah Grew even went so far as to state the conditions in which a miracle must occur: 1) miracles must be unknown in the sense that science will not be able to explain, 2) a miracle must be extraordinary; 3) the miracle must occur in the proper setting, or in times of great need of divine intervention; and 4) a miracle must be directed to a suitable end, being a testament of God's power and protection. By Grew's standards, and in the minds of many of the virtuosi, miracles stopped with the foundation of the Christian church. "In theory, natural religion was

\footnotetext{
${ }^{35}$ Taken from John Ray’s Discourses (1692).

${ }^{36}$ Richard S. Westfall, Science and Religion in Seventeenth Century England (Ann Arbor, MI: University of Michigan Press, 1973), 115.
} 
meant to supplement Christianity, to provide it with a rational foundation; in practice it tended to displace it.",37

"They [the virtuosi] thought of natural religion as a positive aid to Christianity, securing its foundations and perhaps purging it of superstition, but not disproving or displacing it." ${ }^{38}$ Natural religion or philosophy left no room for the existence of the soul. Dr. John Wilkins (1614-1672) in his Of the Principle and Duties of Natural Religion (1675) had three precepts about man and God: 1) man is capable of religion; 2) man is capable of apprehending a Deity; and 3) man is capable of expecting a future state of punishment and reward. Obviously, there is no mention of a greater state of the soul's existence in heaven or in hell, and most obvious of all is the lack of any mention of Jesus Christ, the literal founder of Christianity. In the system of Natural Religion, there is no consideration of anything other than the mechanisms of nature. However, for William Blake, Isaac Newton was the figurehead to a movement of thought that threatened Blake's sensibilities as a spiritual man. Blake would create his work There is No Natural Religion (1788, Fig. 9) as a response to the virtuosi, expressing his distaste for the hubris the virtuosi were considering by trying to quanitfy Blake's God.

\footnotetext{
${ }^{37}$ Ibid., 106.

${ }^{38}$ Ibid., 107.
} 


\section{Blake and Newton, diametrically opposed?}

William Blake, in his work There is no Natural Religion (1788), mocks the virtuosi tenets, and says at the beginning of the work: "[II Man's perceptions are not bounded by organs of perception, he perceives more than sense (tho' ever so acute can discover). [II] Reason or the ratio of all we have already known, is not the same that it shall be when we know more. Therefore, God becomes as we are, that we may become as he is." ${ }^{39}$ Perhaps the most poignant words in Blake's work are included on the last page of There is no Natural Religion: "He who sees the Infinite in all things, sees God. He who sees the Ratio sees himself only." (Fig. 10) These words are only one example of Blake's scorn for the virtuosi. In Blake's generation, the virtuosi were considered and called Deists. The Deists, by attempting to rationalize the spiritual, were limiting their experience of God, thus limiting themselves to the possibility of true salvation. William Blake believed that Isaac Newton and Newton's fame created a false "religion" of rationalist, deistic materialism and therefore, humankind had lost sight of the reality of God. The Deists, with whom Newton was associated after his death, had no need for the spirit, let alone for the Trinity. For Blake, the Deists were dangerous false prophets. After a century of rationalism in lieu of the Enlightenment, Blake became, in his own poetry and art, a proponent of a "mystic-revival" advocated by figures in literature such as Jakob

\footnotetext{
${ }^{39}$ David V. Erdman, ed, The Complete Poetry and Prose of William Blake (New York, NY: Anchor Books, 1988), 2-3.
} 
Bohme (1575-1624) and Blake's contemporary Emaunel Swedenborg (1688-1772).

However, to assume that Newton was not a Christian would be a grave error, but what does differentiate Newton from the later Romantic mystics is his well-known Arian (a rejection of the Trinity) attitudes toward Christianity. ${ }^{40}$

To Newton and Newtonians, God was the "Great Architect" and the doctrine following this idea resembled more closely the Old Testament History and Law than any of the Old or New Testament Prophecies. It then seems fitting that a mind such as William Blake's would begin to reconstruct a mythology that Newton's rationality had tried to kill. ${ }^{41}$ However, it should be noted before trying to establish Blake and Newton as opposites that both were obsessive systematizers. Both sought to find (or in Blake's case, create) a system that could explain phenomena and human existence. ${ }^{42}$

Blake immortalized Newton as a personification of man limited by reason in a color print from about 1795, entitled simply Newton (Fig. 11). The nude male figure sits upon a reef underwater in a dark ocean. The figure is of Newton and he is engrossed in his measurements, holding dividers or compasses, intent on studying the means and methods of the diagram before him. ${ }^{43}$ Newton's figure has no interest in the reef he sits upon or in the fantastic underwater world around him. This figure of Newton is echoed in There is No Natural Religion (Fig. 10), and again with the character Urizen, also known as The Ancient of Days (Fig. 12). The figure of Urizen as the "Great Architect," uses a

\footnotetext{
${ }^{40}$ Richard S. Westfall. "The Rise of science and the decline of orthodox Christianity: A study of Kepler, Descartes, and Newton," in God and Nature: Historical essays on the encounter between Christianity and Science. Ed. David C. Lindberg and Ronald L. Numbers (Berkeley, CA: University of California Press, 1986), 229.

${ }^{41}$ Margaret C. Jacob. "Christianity and the Newtonian Worldview," in God and Nature: Historical essays on the encounter between Christianity and Science. Ed. David C. Lindberg and Ronald L. Numbers (Berkeley, CA: University of California Press, 1986), 253.

${ }^{42}$ Jason Snart. "Blake's awareness of 'Blake in the Newtonian World': William Blake, Isaac Newton, and writing on metal." History of European Ideas 31 (2005): 237-239.

${ }^{43}$ S. Foster Damon, A Blake Dictionary, the ideas and symbols of William Blake, 299.
} 
compass to measure the universe, quantifying and thus limiting all possibility. All of these works use particular figures to represent Blake's sentiments on the work of the virtuosi who vainly try to quantify the spirit. Each of these figures is an important element of Blake's artificial mythology, but they originated, visually, with Blake's criticism of Newton and the later Deists.

However, the true difference between Blake and Newton's systems lies in the type of system each was trying to produce. Blake's system was one of the nature of the soul, the redemption of the spirit, a place where no system existed, in a quantifiable sense. Newton's system was one of hypothesis and experimentation, with only a nod to the possibility of the nature of the spiritual. Blake and Newton were men of imagination, but Blake's system of myth has been obscured due to the nature of its visual vocabulary, a vocabulary that does not translate well in our modern, scientific, and Newtonianinfluenced society. ${ }^{44}$

\footnotetext{
${ }^{44}$ Jason Snart. 'Blake's awareness of 'Blake in the Newtonian World': William Blake, Isaac Newton, and writing on metal," 243.
} 


\section{The Transmutation of the Spirit}

When discussing Blake's system, one cannot overlook the influence of Emanuel Swedenborg. How direct an influence Swedenborg had on Blake's system cannot be discussed in absolutes, nor can Blake's personal feelings about Swedenborg's writings. Historians can see the immediate influences of Swedenborg in Blake's work The Marriage of Heaven and Hell (1790) which was a parody of Swedenborg's De coelo (1758), also known as Heaven and Hell in English and Divine Providence (1764), which expresses Blake's distaste for Swedenborg's strict distinction of good and evil. ${ }^{45}$ However, there are other, less recognizable influences, which will be discussed throughout the rest of this chapter.

Swedenborg was a student of the sciences of the Eighteenth Century and as part of his scientific study, Swedenborg traveled from Sweden to England where Newton was the foremost mind of the century. However, after studying Newton's theories, Swedenborg could not accept Newtonian science. The scientific self-restraint that came with Newton's proclamation hypotheses non fingo, or I feign no hypotheses, did not settle well with Swedenborg whose own methods would include the study and definition of the immateriality of the spirit. ${ }^{46}$

Swedenborg, like Newton before him, and William Blake who followed afterward, was also a systematizer. No great religion, philosophy, or science can exist

\footnotetext{
${ }^{45}$ Inge Jonsson, Emanuel Swedenborg, Trans. Catherine Djurklou (New York, NY: Twayne Publishers, Inc., 1971), 186.

${ }^{46}$ The Latin phrase comes from the end of Newton's Philosophiae Naturalis Principia Mathematica (1687), discussing the cause of gravity.
} 
without a system. For Swedenborg's ontology, he created a theory of series and degrees, which became known as the theory of correspondence. "According to Swedenborg, there is nothing in the entire universe that does not belong to a series or represent a degree in a series, with the exception of the first substance of nature." ${ }^{, 47}$ In this system, there are six series, three higher and three lower. The higher series originates in the first substance or the divine spark of nature, and the second consists of the substances of the first, which includes the element of fire. The third series comprises the four auras of nature. The lower series contain the three kingdoms of nature: mineral, vegetable, and animal. While the lower series can be conceived easily, it is the upper series that seems almost incomprehensible, but it is a system nonetheless. This ontological system is the beginning of the concept of correspondence, which Swedenborg would elaborate upon in his late writings after he turned all his attention to spiritual matters. In his written works before 1745 , Swedenborg maintained that the soul can neither be destroyed nor can it disintegrate for it is an infinite material within a finite extension or capsule. ${ }^{48}$ Inside the capsule, the soul is compressed into a ball, which occupies the smallest space inside the capsule and can easily expand again or take some other shape. When the capsule, or body, dies, the orb of the soul is removed by angels. Swedenborg drew sketches of the membranes of the soul, assuming that there are infinite possibilities of individual variations of souls.

It should also be noted that Swedenborg constructed a system of psychology along that of his ontology in Oeconomia regni animalis in transactions divisa or The Economy of the Animal Kingdom (1740-1741). Swedenborg's psychological system

\footnotetext{
${ }^{47}$ Inge Jonsson, Emanuel Swedenborg, Trans. Catherine Djurklou, 72.

${ }^{48}$ Ibid., 112.
} 
distinguishes between four different functions of the consciousness, the highest being, anima, the soul, the formative substance of human beings. This highest state is a mystery to our simple mechanical brains and thus can only be revealed through analogy or miraculous experience. The anima, he argued, exists in every person, even though the Deists ignored the soul. The second state of the consciousness is our intellectual process, the seat of reason, mens rationalis. The third state is the animus, the vegetable soul, and Swedenborg regarded this state as the seat of men's passions. Finally, the fourth state consists of our sensory organs. Anima, however, is above the domain of words, since words are tied to ideas, which in turn belong to reason or the senses. Anima can and must be accepted by all the lower states for a sense of self-actualization on a spiritual level.

The combination of Swedenborg's ontology and psychology was the basis of his theory of correspondence. Swedenborg's correspondence was that of the soul and the body, only heavenly beings such as angels had this harmony of awareness of body to soul. While trying to somehow quantify the spiritual so that the mens rationalis could assimilate it, Swedenborg turned to the use of Egyptian hieroglyphics and emblems. Swedenborg believed that the Ancient Egyptians had a wisdom that allowed them to use a form of correspondence designated with hieroglyphic characters, which could express the natural and the spiritual simultaneously. By understanding these visual representations, Swedenborg believed that one could reclaim the wisdom of the Scriptures, which had been lost in Europe through a process of censorship, translation, and religious dilution. However, there is no evidence that Swedenborg was particularly interested in the written Egyptian symbol, but like so many thinkers of the Enlightenment, the hieroglyph was a representation of a time when perhaps the wisdom 
of the soul was a bit more pure. ${ }^{49} \mathrm{~A}$ deeper knowledge of the past and an interest in the writings of ancient peoples, philosophers, and alchemists belong to the realm of Hermeticism and Gnosticism, which will be discussed shortly.

Swedenborg's writings after 1745 turn to the purely spiritual, and have been widely printed by the followers of the New Church, the church founded by Swedenborg toward the end of his life. William Blake's involvement with the Swedenborgian movement has been written about widely, mostly by Swedenborgians. One cannot deny that Swedenborg was an influence on Blake's work, and was perhaps a target of Blake's derision as well. "Blake received decisive impulses from Swedenborg, not least concerning the interpretation of the Bible; and his reading of newly translated works such as Divine Love and Wisdom and Divine Providence (1763-1764)—a temperamental reading with pen in hand—aroused his need for a personal stand on problems of decisive importance. ${ }^{50}$ Annotating Swedenborg's text, Blake denounced Swedenborg's writing with such phrases as 'Lies \& Priestcraft,' 'Cursed Folly,' and, most seriously, 'Predestination! ${ }^{51}$

Swedenborg's system was only one of many which Blake would embrace wholeheartedly, then reject violently, and later begin to assimilate into his own system. "Swedenborg had been a sort of second Bible to him [Blake] from childhood, and the influence even of his 'systematic reasoning' remained with him as at least a sort of groundwork, or despised model. ${ }^{, 52}$ The mysticism of Swedenborg's theories and doctrines were fodder to William Blake, visual and mental images that could be

\footnotetext{
${ }^{49}$ Ibid., 113.

${ }^{50}$ Ibid., 186.

${ }^{51}$ Peter Ackroyd, Blake, a biography, 147.

${ }^{52}$ Mark Schorer, William Blake: the Politics of Vision, 106.
} 
appropriated to form a system of poetry and myth rich with analogy. In addition, although Swedenborg differed greatly from the virtuosi by giving scientific credence to the soul, his system was still neither pure nor conceivable to Blake and his sensibilities. Many of Swedenborg's beliefs seemed too constricting to Blake's fiery imagination, but in so many ways Swedenborg provided Blake with the basic vocabulary to mythologize the soul, and form the most profound of analogies in text and image of Blake's work. Both Swedenborg and Blake had such strong and descriptive imaginations, however, Blake would have to continue to look elsewhere for the finer tools to build his own system.

\section{The Hermetic and Gnostic Reactions}

Jos van Meurs writes of Blake's mythology: "He [Blake] is a typical romantic artist and man of feeling, who considered the modern world's dependence on logicalsystematical thinking as a pitiful limiting of a fully developed spiritual-physical life. A central myth may be distinguished, but it undergoes constant transformation, while Blake inserts new elements and sometimes changes the symbolic functions of its figures." 53 However, Blake's intentions for constructing a mythology were clear. He was waging a mental war against the "mechanistic and disintegrative world picture of Western faith and

\footnotetext{
${ }^{53}$ Jos van Meurs. "William Blake and his Gnostic Myths," in Gnosis and Hermeticism from Antiquity to Modern Times. Ed. Roelof van der Broek and Wouter J. Hanegraaff (Albany, NY: State University of New York Pres, 1998), 299-300.
} 
science.” In the mythology Blake constructed, Urizen was the enemy of the spirit. Urizen is a tyrannous God of Reason, coupled with the accusing and punishing authoritarian creator and lawgiver of the Old Testament. As reason and the old law, Blake calls Urizen the "Satan of Selfhood," who is "God of this World." Therefore, in this system, a type of antagonist emerges (Fig. 13). Urizen is the god of the Old Testament in some aspects, a god who rejects the prophecy of the coming of Christ. Urizen binds all man to the unimaginative accordance to the laws, and inhibits the growth of spirit.

Blake's reaction against rationalism was part of a trend for Romantic thinkers, who had a renewed interest in the occult and Hermetic philosophy that had been so popular in Europe during the Renaissance. There is no definitive evidence that Blake was a modern Gnostic or Hermeticist, but there are indications in his art and writings that he was familiar with these concepts. Figures like Emanuel Swedenborg and Jakob Bohme (1575-1624) sparked ideas that Blake used in his formative system of myth. Bohme, in particular, appealed to Blake after Swedenborg's influence had waned. Bohme, as Blake, was an autodidact, yet he came to be one of the greatest Christian mystics. Bohme's most important contribution to Blake's system was the "metaphysical basis of his [Bohme's] cosmology." ${ }^{54}$ Blake's view of creation, good, and evil, was more compatible with Bohme's. In Bohme's cosmology, Blake was further supplied with “a concept that was no less than vital to his work, and with any number of symbols by means of which he could dramatize it [a system]." Blake was working backward from Swedenborg to Bohme, and it is with Bohme that a Hermetic element was introduced to Blake.

Perhaps the most 'Hermetic' concept Blake drew from his readings of both mystics was the "concept of the androgyny of God; cosmic man seen as a unity of

\footnotetext{
${ }^{54}$ Mark Schorer, William Blake: the Politics of Vision, 109.
} 
masculine and feminine elements; and the symbolic analogies between things above and below." $" 55$ The very Christian concept of the Trinity deals with the three-in-one form of existence on the spiritual level, therefore, the Hermetic concepts of the union of trichotomies appealed to Blake.

In 1804, in a more Hermetical vein, Blake created characters called the "Four Mighty Ones," or “The Four Zoas," (Fig. 14). "The Four Zoas" represented the four dimensions of what Blake thought to be the human psyche, as well as parts of what consisted of Albion or the Universal Man. Urthona or Los (Fig. 15) are parts of imagination and inspiration. Urizen (Fig. 13), the antagonist, was named by a play on the words “your reason.” Luvah (Fig. 16), fallen from Orc, represented desire. And finally, Tharmas was compassion. As long as the four worked in harmony, and as long as the masculine and feminine sides of each were in balance, the Universal Man/Albion could be whole. The feminine sides of the "Four Mighty Ones," correspond thus: Urthona/Los and Enitharmon (Fig. 17), Urizen and Ahania (Fig. 18), Luvah/Orc and Vala (Fig. 27), and finally Tharmas and Enion. Like the splitting of Adam and Eve in Judeo-Christian tradition, Blake used the Zoas and the Emanations throughout his system of myth.

It is in Blake's Prophecies that the true manifestations of Blake's figures in his artificial myth are visible, first in America (1793) with the introduction of Orc (Fig. 19). Orc is described as a youthful "spirit of freedom...intense, naked, a human fire," helping to defeat the Britons and their "fossilized Guardian Angel of Albion (England)" and push them back to the coast of England "in spite of the divine assistance of the god Urizen."56

\footnotetext{
${ }^{55}$ Jos van Meurs. "William Blake and his Gnostic Myths," 284.

${ }^{56}$ Ibid., 296.
} 
In Europe (1794), Orc takes on a different quality than that of a "spirit of freedom;" he is now a personification of rebellion while Albion (England) is the combined repressive aspects of the "rationality" and natural religion sweeping through its lands due to figures like Newton. Newton's god is Blake's Urizen, the oppressive god of Reason. Pictured on Plate 1 of The First Book of Urizen (1794), Urizen is among the stone tablets of the Book of the Law, and from this place tries to keep "the spirits of life" in chains (Fig 13). Thus, another character, perhaps the most important in Blake's system, is introduced in the Prophecies. Los, the spirit of creation, helps to free Orc in Europe, thus freeing all of Europe from Urizen's stifling Reason. In Blake's mythology, there are spiritual battles between characters like Urizen and Los to free humanity from suffocating Reason to allow them to be saved. To Blake, Albion (Fig. 27) was representative of humanity, or England, and it was England that neede to be awakened from the sleep of Reason.

The concept of halves and implied androgyny of other characters is reminiscent again of Hermetic images in alchemical manuscripts of the hermaphrodite, however Blake's conception of the visual representation may have only been assimilated to set into his system. The relationship of Zoa and Emanation is more reminiscent of God/Consort in Hindu mythology, which will be discussed, in the next chapter. 


\title{
Chapter Two - Nineteenth Century Oriental Myth and Mythography as Portrayed by William Blake's Painting and Prophetic Books
}

\author{
“...Rintrah gave Abstract Philosophy to Brama in the East. "57
}

\section{Britain and the Orient}

Beginning in the Seventeenth Century, England expanded its rule to areas of the world then accessible by use of modern fleets of trading and naval vessels. With the establishment of the East India Company, England expanded their Empire and thus gave British artists a new realm to explore. By the 1770 s, India had become a mythical land in its own right. A land of spices, of heat, of color and wild animals, India was Britain's land of mysticism. Through art, images came back to the British people. Images of the Hindu religion and of Indian fashion came back to Britain to enthrall the aristocracy and the middle class (Fig. 20). It was through portfolios of drawings of the numerous Hindu

\footnotetext{
${ }^{57}$ Excerpt from The Song of Los (1795).
} 
temples and monuments that an understanding of such a foreign faith came to be appropriated by artists in Britain.

Information on Indian native religion and mythology also began trickling back to Britain in books such as John Zephaniah Holwell's (1711-1798) three-volume set on Hinduism and Indian cosmology, which were published in 1767. With Holwell's essays, studies of Indian life, antiquities, and religion soon became normal for the classically educated Englishman to possess. ${ }^{58}$

One such proponent of bringing the arts, myth, and theology of India to Britain was Sir William Jones (1746-1794). Jones was trained traditionally in the school of medieval thought where it was considered that man possessed three faculties: memory, the study of facts, which gave rise to history; ratiocination or logical reason, which was the basis of science and philosophy; and imagination, which was the provenance of art. For Sir William Jones in 1784, European superiority lay in ratiocination while the Indian superiority lay in Imagination. If imagination is the provenance of art, then the impact of Indian culture, myth, and religion was influential to the artists of Britain. ${ }^{59}$

The proliferation by the media of Indian religions and myths, as well as the mythologies of Ancient Greece and Rome in the in the late Eighteenth and into the Nineteenth Century provided inspiration to England's artistic, literary, and occult circles, and influenced such artists as John Henry Fuseli (1741-1825), John Flaxman (17551826), and William Blake. This strong current of incoming mythography into England from India, as well as from other parts of the British Empire had a profound impact on

\footnotetext{
${ }^{58}$ Mildred Archer and Ronald Lightbown, India Observed: India as viewed by British Artists 17601860 (London: Victoria and Albert Museum, Trefoil Books, 1982), 12.

${ }^{59}$ George D. Bearce, British Attitudes Towards India 1784-1858 (Oxford: Oxford University Press, 1961), 22.
} 
artists throughout the Nineteenth Century, generated numerous movements in British art, such as the British Romantics, the Pre-Raphaelites, and later Symbolists.

In this chapter, I will analyze and emphasize the tradition of mythography, both collected from the East and created through the use of Biblical references which resulted in Blake's unique artificial mythology as well as the use of myth as allegory in Blake's overall personal creation of the 'Divine Vision.' Attention will be paid to connections between the availability of Hindu mythologies and the allusions drawn in Blake's artistic work from Eastern influences as well as the impact of Blake's doctrines and ideals on later artists and art movements.

\section{Britain, Imperialism, and the East}

How can one find a clear path to a man's thoughts except by sifting through daunting and cryptic passages of text and graphics? The title of painter-poet was applied to Blake, and the scholarship following Blake's death in 1827 applied such anecdotes to the man as eccentric, mad and mystical. However, in the Twentieth Century his eccentricity has been viewed as original, ingenious, and at times controversial. Difficulty in analyzing Blake stems from the separation of visual work and text, which were forced 
apart by the disciplines of visual art and poetry. The difficulty also arises from Blake's unorthodox style in both media.

In aspects applying to art, Blake was anti-establishment and he openly conducted a vendetta against Sir Joshua Reynolds, the president of the Royal Academy of Art in England. ${ }^{60}$ Blake's unique interpretation of theology differentiated him from many other artists and writers during his lifetime; however the influence of mythology, both germane to the British Isles and to that of the lands ruled by the British Empire, provided rich materials that reinforced Blake's unique religious views.

As has been discussed in the Introduction and previous chapter, Blake was a man who took much from the mythology, religion, philosophy, and revolution that thrived in Britain and the Continent during his lifetime. This wealth of culture and art is what inspired Blake to create his own complex mythography with roots in Swedenborg's doctrine, Hermetic notions, and mythological foundations both of European origin and that of the East. The so-called 'Oriental Renaissance' brought about by the expansion of the British Empire was a sure source of inspiration to the poets and painters such as Gabriel Dante Rossetti (1828-1882), Percy Bysshe Shelley (1792-1822), and Samuel Taylor Coleridge (1772-1834), but Blake in was the avant garde in terms of assimilating the mythographic and cultural sources from the East. The difference, however, between Blake and these Romantic figures is that in shaping his vision, Blake looked backward to an earlier age of strange religious sects, theological peculiarities, and perhaps heresies, such as the Gnostic Heresy. This culmination of Eastern mythology, obscure theologies, Scandinavian and British myth and politics marks Blake in his own time as a sort of eccentric. However, Blake's interest was by no means eccentric nor was his debate of

\footnotetext{
${ }^{60}$ Malcolm Cormack, William Blake: Illustrations of the Book of Job, vi.
} 
reconciling myth and religion. Eighteenth-Century mythographers had been comparing, describing, and criticizing world religions by a dominant Judeo-Christian standard before Blake was an active artist-poet. Perhaps this somewhat one-sided interpretation of world religions in mythographies inspired, as well as dispelled, Blake's conventionality. Blake would adamantly state that "All Religions are One," (Fig. 21) and declared that all religions, structured and codified were corrupt forms of poetry. ${ }^{61}$

As for Eastern myth being available to the British populace, perhaps the most influential, and, visually rich, source was Edward Moor's (1771-1848) The Hindu Pantheon printed in London in 1810. This volume included detailed descriptions of the pantheon of Hindu gods as well as beautiful engravings of the gods, goddesses and their attributes. The primary artist for the engravings in Moor's The Hindu Pantheon was Moses Haughton. There is an interesting connection between the engraver of the images of The Hindu Pantheon and William Blake through Blake's contemporary and friend Henry Fuseli. Fuseli employed Haughton on a regular basis to engrave many of Fuseli's own compositions and thus he served as a connection between the 1810 printing of The Hindu Pantheon and William Blake's assimilation of predominately Indian composed figures and images. ${ }^{62}$

Another important work for Blake was François Balthazar Solvyn's (1760-1824) Costumes of Hindostan from 1806. This text contained sixty colored engravings with descriptions in English and French. It is also important to note that John Flaxman, an essential supporter, friend, and contemporary of William Blake, drew an example of an Indian woman in costume. The Hindu Pantheon and Costumes of Hindostan were being

\footnotetext{
${ }^{61}$ David Weir, Brahma in the West: William Blake and the Oriental Renaissance, 3.

${ }^{62}$ Ibid., 21-22.
} 
circulated between Blake's artist friends (Fig. 20). ${ }^{63}$ As for religious texts, an English translation by Charles Wilkins (1749-1836) of the Bhagavad-Gita was available in 1785, predating any other translations in Europe. ${ }^{64}$ In Blake's Descriptive Catalogue from 1809, he refers to the "Geeta" in reference to a drawing called The Bramins. Surely, this reference is to the Bhagavad-Gita which Blake called "the Hindoo Scriptures," alluding to the text's importance as "scripture" and thus placing it on a level equal to that of the Christian Bible. ${ }^{65}$ It is very possible that if Blake knew of Wilkins' translation of the Bhagavad-Gita he also knew of the writings of Sir William Jones who commented on the ingenious imagination the people of India possessed. ${ }^{66}$ This comparison between two sacred books would have been appealing to Blake, the idea of Krishna being the literal "Jesus, the Imagination" of the East. ${ }^{67}$

\footnotetext{
${ }^{63}$ Piloo Nanavutty. "William Blake and Hindu Creation Myths." In The Divine Vision, Studies in Poetry and Art of William Blake born November 28, 1757. ed. De Sola Pinto, Vivian. (New York, NY: Haskell House Publishers, Ltd., 1968), 169.

${ }^{64}$ A. M. Hammacher, trans. Langham, Tony and Peters, Plym. Phantoms of the Imagination: Fantasy and Literature from Blake to Dali (New York, NY: Harry Abrams Publishers, Inc., 1981), 30-31.

${ }^{65}$ David Weir, Brahma in the West: William Blake and the Oriental Renaissance, 88.

${ }^{66}$ Kathleen Raine, Blake and Antiquity (Princeton, NJ: Princeton University Press, 1977), 89.

${ }^{67}$ Kathleen Raine, The Human Face of God: William Blake and the Book of Job, 13.
} 


\section{Brahma and Ezekiel}

Any definite proof that Blake ever actually read any of the Asiatic texts available during his lifetime is circumstantial at best, however, there are clear textual indications that Blake, at the very least, knew of the Hindu creator god Brahmā. In Blake's The Song of Los (1795), Brama (sic) is mentioned in the passage:

When the Children of Los give Urizen's laws to the nation, Rintrah gave Abstract Philosophy to Brama in the East. ${ }^{68}$

The concept of the Hindu god Brahmā would have been of particular interest to Blake because Brahmā was a god of creation. The Book of Genesis challenged Blake's power of symbolic interpretation, and he eventually set out in the last years of his life to revise the Christian interpretation of Creation.

In Blake's version, the concept of something out of nothing is the human and lessthan sublime understanding of creation. For Blake, the idea of matter "pre-creation" was not chaos and void, but quintessentially God. The creation of the physical, as mankind knows it, was merely a splintering of God, a separation of God's sublimity. ${ }^{69}$ In a Christian tradition, one might suppose that this splintering dealt with the idea of the Son, an intrinsic part of God who was present at Creation. However, Blake addressed the idea of the Father/God and the Son/Jesus in a very different manner than what most Christian traditionalists might know or even consider. Again, Blake's myriad and oftentimes complex system of beliefs, reflected that Blake viewed God in 1810 from A Vision of the Last Judgment thus: "Thinking as I do that this Creator of this World is a very Cruel

\footnotetext{
${ }^{68}$ S. Foster Damon, A Blake Dictionary, the ideas and symbols of William Blake, 58.

${ }^{69}$ Ibid., 151.
} 
Being and being a Worshiper of Christ I cannot help saying the Son O how unlike the Father...,70

In relation, the Hindu Brahmā is the supreme Hindu god who is the universe seen and unseen. This interpretation of a Hindu being, supreme in nature, is, basically, a monotheistic view; however, there is a subtle difference between Brahma and Brahmā with the last "a" being long in sound. Brahma "generated" the gods as he "generated" the universe and all things in it. Everything, gods and the corporeal world, are manifestations of Brahma, parts of a being that is with and without shape. Brahma is also perishable and imperishable; the imperishable Brahmā is the supreme, omnipotent being, the perishable Brahma is the world and all things transcendental. ${ }^{71}$

Brahmā is a manifestation of a larger whole as are the gods Vishnu and Šiva. Brahmā is the Creator, Vishnu is the Maintainer, and Šiva is the Destroyer, thus forming a triad of deities, which encompass all aspects of life and the sublime. ${ }^{72}$ Edward Moor further elaborated in The Hindu Pantheon on this description of each god by saying that Brahmā is Matter, Vishnu is Spirit, and Šiva is Time. This triad is similar to the Trinity in Judeo-Christian beliefs, but the similarity stops after the similarity in number. Because all of the mythologies coming from India were from Christianized travelers between England and India, the interpretations of Indian religion and myth had Christian bias. ${ }^{73}$ However, Blake does not borrow from the three Hindu aspects of the triadic universe, but

\footnotetext{
${ }^{70}$ A. D. Nuttall, The Alternative Trinity: Gnostic Heresy in Marlowe, Milton, and Blake (Oxford, England: Clarendon Press, 1998), 7.

${ }^{71}$ W. J. Wilkins, Hindu Mythology, Vedic and Puranic, $2^{\text {nd }}$ ed. (London: Curzon Press, 1973), 95.

${ }^{72}$ Ibid., 99.

${ }^{73}$ Piloo Nanavutty, "William Blake and Hindu Creation Myths," 165-166.
} 
uses Christian categories specifically in the text of Jerusalem, the Emanation of the Giant Albion (1820): Creation, Redemption, and Judgment. ${ }^{74}$

In an artistic and visual respect, Moor also informs the reader of The Hindu Pantheon that Brahmā is usually represented with four faces or heads which could represent the four quarters of the universe he created, elements by which he had been made, or refer to the sacred Vedas one of which issued from each mouth in song. Brahmā is colored red for it is a color specific to creative powers in Hindu tradition. ${ }^{75}$

In Plate 3 of The Hindu Pantheon (Fig. 22), Brahmā is portrayed in Haughton's engraving as a seated figure, not only having four heads, but four arms as well. Brahmā, with only three faces visible, sits in a position of meditation, each hand holding a specific attribute. Moor explains the attributes thus:

[h]aving in his hands, what his descendants the Brahmāns, are supposed to have often in theirs, viz., a portion of the Veda, or scripture; a spoon, used in the performance of sacred ceremonies, for lustral water; a rosary for assisting abstraction, in contemplating the attributes of God, a bead being dropped at the mental recitation of each of his names, which the mind is intensely fixed on the idea of the name, which is significant of some attribute, excites; and fourthly, a vessel to contain water of ablution, a preliminary essential to prayer or sacrifice. ${ }^{76}$

In Plate 4 of The Hindu Pantheon (Figure 23), Brahmā is posed in his capacity by which his descendants, the Brahmin, were to function. Moor describes the engraving thus:

Plate 4 is copied from a beautiful painting, in the collection of Colonel Stuart; in which Brahmā is officiating as a Brahman, at one of the daily sacrifices which individuals of that tribe are compelled to offer. His consort, or Sacti, Saraswati, is in attendance, and presenting him with the holy utensils. A sort of magical square is seen near the carpet, the sacrificial fire, and sundry implements used on these

\footnotetext{
${ }^{74}$ Ibid., 174.

${ }^{75}$ Edward Moor, intro. Feldman, Burton, The Hindu Pantheon (New York, NY: Garland Publishing, Inc., 1984), 6.

${ }^{76}$ Ibid., 11.
} 
occasions: on which points we shall, when describing the plates containing these implements, bestow a further portion of our attention. ${ }^{77}$

These clear descriptions, as well as wonderfully rendered representations of Brahmā's figure, unique to the British, were surely an inspiration of sorts to the artist. One of Blake's works that emulates the same figural structure of Haughton's Brahmā is in a watercolor painting entitled Ezekiel's Vision (Fig. 24) from the Illustration of the Old Testament, Ezekiel I 4-28 (1803-1805). This work illustrates a passage from one of the most enigmatic and visually daunting prophetic books of the Old Testament. In this book, the prophet Ezekiel sees in a vision the figure of a cherub and what is construed to be zoomorphic representations of the four Gospel writers, also called the tetramorph. The vision of the tetramorph is first seen in the Old Testament book Ezekiel and is echoed again in the Book of Revelation Chapter 4 versus 7-8:

And the first beast was like a lion, and the second beast was like a calf, and the third beast had a face of a man, and the fourth beast was like a flying eagle. And the four beasts had each of them six wings about him; and they were full of eyes within: and they rest not day and night, saying, Holy, holy, holy, Lord God Almighty, which was, and is, and is to come. ${ }^{78}$

The appeal of the Book of Ezekiel and the overall theme of vision contributed much to the imagination of an artist like William Blake. In Blake's Ezekiel's Vision, the cherubim is portrayed as an androgynous figure, male in musculature, but with three visible faces, and alluding to a fourth pointing who is pointing in a cardinal direction, as are the others. Unlike Brahmā in Haughton's engravings, this cherubim has only two arms, which are spread wide. The cherubim has four wings that resist the wind of the tempest, which surrounds the central figure.

\footnotetext{
${ }^{77}$ Ibid., 11 .

${ }^{78}$ Rev. 4:7-8 KJV
} 
Ezekiel's description of the cherubim differs from Blake's interpretation by having four heads not all of which are human, but are instead the symbolic tetramorph of later Christian theology. Ezekiel's Vision, which is visually confusing and to be taken perhaps metaphorically instead of literally, describes the cherubim in Chapter 1 verses 5-15:

Also out of the midst thereof came the likeness of four living creatures. And this was their appearance; they had the likeness of a man. And every one had four faces, and every one had four wings. And their feet were straight feet; and the sole of their feet was like the sole of a calf's foot: and they sparkled like the color of burnished brass. And they had the hands of a man under their wings on their four sides; and they four had their faces and their wings. Their wings were joined one to another; they turned not when they went; they went every one straight forward. As for the likeness of their faces, they four had the face of a man, and the face of a lion, on the right side: and they four had the face of an ox on the left side; they four also had the face of an eagle. Thus were their faces: and their wings were stretched upward; two wings of every one were joined one to another, and two covered their bodies. And they went every one straight forward: whither the spirit was to go, they went; and they turned not when they went. As for the likeness of the living creatures, their appearance was like burning coals of fire, and like the appearance of lamps: it went up and down among the living creatures; and the fire was bright, and out of the fire went forth lightning. And the living creatures ran and returned as the appearance of a flash of lightning. Now as I beheld the living creatures, behold one wheel upon the earth by the living creatures, with his four faces. ${ }^{79}$

This description seems only to be one influence on Blake's work which includes the enraptured Ezekiel at the bottom of the work, the swirling wind and eyes coming from Ezekiel's head like dream ether.

Above the cherubim is a figure of an older man who Blake identifies as Urizen, the Divine Imagination before the corruption of Moral Law, with hand raised in benediction. ${ }^{80}$ Urizen is enthroned and can be thus associated with Blake's concept of Vehicular Form, which is the form of the soul's energy and is most naturally symbolized

\footnotetext{
${ }^{79}$ Ezek. 1:5-15 KJV

${ }^{80}$ Leopold Damrosch, Jr., Symbol and Truth in Blake's Myth (Princeton, NJ: Princeton University Press, 1980), 125.
} 
in its divine state as a chariot or throne depending on the representation of the god as static or dynamic. The "chariot" is an allegorical symbol from the Renaissance often used in depicting the triumph of gods or virtues. ${ }^{81}$ In the Bhagavad-Gita, Krishna, who is an avatar or incarnation of the god Vishnu, is the Divine Imagination or force that propels the hero, Arjuna, toward oneness with the divine. In Ezekiel, God is visualized in a chariot or vehicle of sorts, surrounded by four "living creatures" filled with eyes and resembling an eagle, an ox, a lion, and a man. In the Book of Revelation, Ezekiel's chariot has become a throne again surrounded by the four beasts. ${ }^{82}$ The Old Testament vision as well as the New Testament version is thus combined in Blake's Ezekiel's Vision and the true fourfold tetramorph is represented by four distinct faces gazing outward in the margins behind the swirling of wind and cherubim wings. ${ }^{83}$ However, the figure of Urizen could also be the fourth face of the cherub, alluding to a conflation of context. The cherubim is not only a vision of Ezekiel the prophet, but also a representation of the giant Albion in Blake's system.

Although Blake's Ezekiel's Vision is very far removed in context from anything remotely Hindu in nature, figuratively there is a connection between the central figure and Moor's description of Brahmā. This similarity in figural elements, between Blake's characters in his prophetic books, and those represented as Hindu deities in Moor's text, is not confined to just the representation of Brahmā. Another example of Blake's visual quotation of Haughton's engraving in The Hindu Pantheon is Plate 53 from Blake's Jerusalem, the Emanation of the Giant Albion (Fig. 25).

\footnotetext{
${ }^{81}$ The chariot is a symbol used cross-culturally, from art of the ancient Greeks, to early Hindu art.

${ }^{82}$ Northrop Frye, Fearful Symmetry, a Study of William Blake (Princeton, NJ: Princeton University Press, 1947), 272-273.

${ }^{83}$ Leopold Damrosch, Jr., Symbol and Truth in Blake’s Myth, 125.
} 


\section{$\underline{\text { Beulah and Padma-Devi }}$}

The quality that distinguishes Blake from many artists of his age, is his use of image and text as seen in Plate 53 of Jerusalem, the Emanation of the Giant Albion (Fig. 25). At the top of the page is a seated female form, perched upon a sunflower, hands under her chin to hold up a head heavy with a tiered crown. This figure is identified in the text below the image as the physical manifestation of Beulah, which is more a place than an individual character in Blake's original pantheon of characters in his prophetic books. Beulah might be compared to the ideal of Utopia or even the traditional Christian idea of Eden, but to Blake Beulah is the realm of the Subconscious and the source of poetic inspiration and dreams. ${ }^{84}$ Beulah stands between Eternity, Blake's Eden, and Ulro, the world as mankind knows it to be. Beulah is a refuge from the intensity of Eternity and the drudgery of Ulro. ${ }^{85}$

A similar image of a female figure seated upon a bloom can be found in Moor's The Hindu Pantheon in the depiction of Padma-Devi or as Moor recounted Pedma-Devi (Fig. 26). The word "padma/pedma" meaning "lotus," and "devi" meaning "goddess," this figure is literally the "lotus goddess." The Padma-Devi represents the tradition of a goddess that precedes and predates any notions of Brahmā and the triad of gods in the sense that Padma-Devi is a concept beyond that of a deity; instead, she embodies the

\footnotetext{
${ }^{84}$ S. Foster Damon, A Blake Dictionary, the ideas and symbols of William Blake, 42.

${ }^{85}$ David Weir, Brahma in the West: William Blake and the Oriental Renaissance, 77.
} 
earth and nature itself. Padma-Devi is sometimes called, in different incarnations or more simply "manifestations," Lakshimi or Sri who is the wife of the god Vishnu. ${ }^{86}$ Originally, and perhaps most importantly, Padma-Devi is the Hindu version of the "mother goddess" that is a seemingly universal figure in images found throughout the Near East and as far away as Eastern Europe.

Moor relates that Padma-Devi is the emblem of feminine beauty and, in turn, Haughton illustrates Padma-Devi in her "classical" pose. The deity is seated upon a lotus blossom and is attended by two female figures on each side of the lotus platform. Two of the four hands of the goddess are posed in a mudra of benediction before her bare and voluptuous breasts. Padma-Devi holds two lotus blossoms in two lifted hands, which are the bases of a pair of flanking, yet small, elephants. From lifted trunks, the elephants spout water upon the broad-hipped patroness of Hindu fertility. ${ }^{87}$

The lotus plays an important symbolic role in interpreting Hindu iconography, but for Blake the lotus was utterly foreign to his English knowledge of everyday gardening, thus a sunflower is employed as a familiar replacement to the exotic lotus blossom. However, the lotus figures again in another image in Hindu art and myth, which is very similar, visually, to another dramatically colorful and stunning passage in Blake's work, Plate 14 of Jerusalem, the Emanation of the Giant Albion.

\footnotetext{
${ }^{86}$ W. J. Wilkins. Hindu Mythology, Vedic and Puranic, 127.

${ }^{87}$ Heinrich Zimmer. Ed. Campbell, Joseph, Myths and Symbols in Indian Art and Civilization, 92.
} 


\section{Albion, Vishnu, and Garuda}

Plate 14 of Jerusalem, the Emanation of the Giant Albion, portrays Albion, the great aboriginal giant that is England who is the father of mankind, in repose and dreaming (Fig. 27). Albion dreams in his physically vulnerable slumber because he had lost the Divine Vision by hiding his Emanation, Jerusalem/Vala, from her bridegroom, Jesus. $^{88}$

Jerusalem, a female figure, hovers above Albion's prone form. She is surrounded by wing-like structures, floral in design and appearance. Albion sleeps, his left hand cradling his head while his feet rest upon a crouching angel. A rainbow frames a cloudy night sky with stars and moon. The arrangement of figures in Plate 14 is mimicking a passage from Hindu myth and sculpture.

A version of the creation of Brahmā deals with the deity coming forth from the navel of Vishnu where Brahmā is grown from a lotus (Fig. 28). From this lotus, Brahmā bids all worlds into existence. ${ }^{89}$ At Vishnu's feet is Lakshimi, his consort, who strokes his feet and legs. Vishnu lies upon a bed of coiled serpents, which float upon water, a Hindu cosmic substance when combined with images of the deities. ${ }^{90}$ This visual passage is mentioned in Moor's The Hindu Pantheon. This image of Vishnu in recumbence with Brahmā hovering above his torso is inspirational visual material and appears to have been assimilated by Blake.

\footnotetext{
${ }^{88}$ S. Foster. Damon, A Blake Dictionary, the ideas and symbols of William Blake, 9.

${ }^{89}$ Edward Moor, intro. Feldman, Burton, The Hindu Pantheon, 10.

${ }^{90}$ Heinrich Zimmer, Ed. Campbell, Joseph, Myths and Symbols in Indian Art and Civilization, 61.
} 
Yet another image by Blake that conveys a working knowledge of Hindu myth and Haughton's engravings is that of a figure from Plate 78, again from Jerusalem, the Emanation of the Giant Albion (Fig. 29). The figure of a man sits upon bare rocks, facing towards the sunset to the left, however this body of a nude male is topped with the head of a bird. The composite birdman sits with a hand poised under its chin. The head of the birdman is like that of an eagle with a curved, sharp beak and keen eyes. This predator bird has a coxcomb atop its head and wattles, which are more reminiscent of a chicken or turkey. Apparently, this composite is a creation of the imagination and not a true representation of any true bird in nature. This figural resemblance to a figure in Hindu mythology comes with the magical companion to the god Vishnu named Garuda. Garuda is the vehicle, or vahānā, of Vishnu and as a vehicle; Garuda bears Vishnu upon his shoulders or upon his back. ${ }^{91}$

The figure of Garuda is that of a man with a hooked nose like a beak and a set of wings upon his back. In this form, Garuda resembles what Western culture might consider an angel, man in figurative form, but supernatural in that he has wings and a beaked nose. ${ }^{92}$ Another illustration (Fig. 30) shows Garuda as a massive figure with Vishnu and his consort riding upon Garuda's back. This image is more like Blake's birdman with its coxcomb. This combination of animal and human, a hybrid, was not an uncommon motif in Indian art and myth, but is not so common in Western art after explorations by the French in Egypt in the Seventeenth Century which may have more available to Blake to assimilate into his own work.

\footnotetext{
${ }^{91}$ Heinrich Zimmer, Ed. Campbell, Joseph, Myths and Symbols in Indian Art and Civilization, 76.

${ }^{92}$ W. J. Wilkins, Hindu Mythology, Vedic and Puranic, 450.
} 
The incorporation of Indian images in Blake's Jerusalem, the Emanation of the Giant Albion is not surprising in view of his words in the Descriptive Catalogue of 1809. Again, the Charles Wilkins translation of the Bhagavad-Gita is an important contribution to British academia and art. ${ }^{93}$ Northrop Frye comments: "New contributions were pouring in from as far afield as Persia and India, and Blake was among the first European idealists able to link his own tradition of thought with the Bhagavad-Gita."94

Blake was not a theologian, but his religious study of Swedenborg's philosophy put Blake in a position to appreciate a Hindu system at the end of the Eighteenth Century. Blake did not exclude the sacred texts of world religions. Blake's reference to Wilkins' translation of the Bhagavad-Gita as "the Hindoo Scriptures" shows that the poet understood the Bhagavad-Gita in terms of the text as a kind of bible or sacred code. For Blake, a Hindu bible could take a place beside the Hebrew and Christian testaments as yet another book of poetic truths subject to manipulation by priests and clergy for the manufacture of moral law. ${ }^{95}$

Further evidence for the connection between Blake's system of myth and that of Hinduism is Blake's Albion and the Hindu deity Brahmā. Both figures are fourfold giants, Brahmā having four heads representing the Vedas, and the quarters of the universe. Albion is also fourfold by the Zoas or aspects of man which compose Albion. The four aspects of Albion demonstrate a tendency to represent the basic quartering of the universe, physical, and spiritual, as well. Albion, the creator of Man, is composed of the body or Tharmas (west), his reason or Urizen (south), his emotions or Luvah (east), and

\footnotetext{
${ }^{93}$ David Weir, Brahma in the West: William Blake and the Oriental Renaissance, 83.

${ }^{94}$ Northrop Frye, Fearful Symmetry, a Study of William Blake, 173.

${ }^{95}$ David Weir, Brahma in the West: William Blake and the Oriental Renaissance, 88.
} 
his imagination or Urthona-Los (north). ${ }^{96}$ Each aspect, or in Blake's terms, Zoa has a counterpoint or Emanation that is systematically similar to the Hindu concept of god and consort. William Blake's illustrations further demonstrate his knowledge of other world systems of mythology. Through his visual passages inside his own system, he has expressed his interest, his knowledge, and appreciation of the world outside his own. With a system in place, Blake, toward the end of his life, began to apply his knowledge and skill to revise other systems, and for him the ultimate system: the Bible.

${ }^{96}$ S. Foster. Damon, A Blake Dictionary, the ideas and symbols of William Blake, 458. 


\title{
Chapter Three - William Blake's System of Myth Applied to the Book of Job
}

\author{
'...the Letter Killeth. ${ }^{97}$
}

\section{The Suffering of Man}

It is inevitable that man will suffer at some point during a lifetime. This is an inescapable fact that humanity has dealt with since the beginning of time. Even as man suffers, he asks the age-old question: why? The Christian Bible deals with many questions concerning humanity and in the Old Testament Book of Job; the question of man's suffering is addressed. Unfortunately, for some theologians and for William Blake, the answer provided by the Old Testament question of "why" is never sufficiently answered. In this chapter, I will examine William Blake's Illustrations of the Book of Job, analyzing how William Blake's personal theological views, artificial mythology, and

\footnotetext{
${ }^{97}$ From William Blake's The Illustrations of the Book of Job, plate 1.
} 
the decisions made upon the execution of the Illustrations of the Book of Job mark the work as a unique interpretation of an ancient text. Emphasis will be placed upon the traditional morality and meaning of the Book of Job in comparison with Blake's interpretation.

A foundation of Blake's system has been established, his religious beliefs explored, and his interest in other mythologies incorporated into his own work. These elements culminated in Jerusalem, the Emanation of the Giant Albion, created five years before the Illustrations of the Book of Job. The Giant Albion is a predecessor of Blake's Job and is part of Blake's personal system of belief and mythology. ${ }^{98}$ To understand the context in which Blake interprets the Book of Job, establishing the importance of Blake's Jerusalem, the Emanation of the Giant Albion and its system is paramount. In Jerusalem, the Emanation of the Giant Albion Blake expresses his personal religious and social beliefs, which serves as a model for understanding his interpretation of the Book of Job.

Considering Blake's basis of the mythology for Jerusalem, the Emanation of the Giant Albion and other prophetic books, Blake's interest in the Orphic mysteries of the Sixth Century BCE, and the Gnostic writings and the writings of Bohme and Swedenborg as well as sources from the Orient, a clear system begins to emerge. Blake's system is not chaotic; in his "prophetic" books Blake's repeats the separation of the whole man into four distinct parts. In Jerusalem, the Emanation of the Giant Albion, the "whole man" is Albion. Albion is comprised of four "living creatures;" Urthona or Los, Imagination; Luvah or Emotion; Urizen or Reason and Tharmas which represents the physical body and its emanations of each part corresponding with female figures: Enitharmon, Vala, Ahania and Enion. This myth or system of thought is entirely Blake's own creation, but it

\footnotetext{
${ }^{98}$ Kathleen Raine, The Human Face of God: William Blake and the Book of Job, 11.
} 
is indebted to Neo-Platonic, Gnostic, and other heterodox doctrines. ${ }^{99}$ The connection between Blake's Albion and Job is based on the afflictions both figures face when confronted with God and morality.

\section{$\underline{\text { Job as Legend }}$}

The culmination of "Imagination" and unique theology in Blake's artistic career is best expressed in one of his last works, the Illustrations of the Book of Job. ${ }^{100}$ In the Illustrations of the Book of Job, Blake tests his artificial mythology by applying it to the sacred words of the Bible. The Old Testament Book of Job had been loved and brooded over by Blake for many years before he finally executed a series of twenty-one watercolors for Thomas Butts (1757-1845) around 1805 to $1810 .{ }^{101}$ A second series was executed in 1821 for John Linnell (1792-1882). Linnell had seen the Butts series and had expressed tremendous admiration for it. Linnell began tracing outlines to Blake's Job designs and with Blake's consent in 1823 began to collaborate with the artist to produce the engravings for the Illustrations of the Book of Job, the last complete work by

\footnotetext{
${ }^{99}$ Andrew Wright, Blake's Job: A Commentary (Oxford: Clarendon Press, 1972), xvii-xviii.

${ }^{100}$ See page 30 and the comments on "Imagination."

${ }^{101}$ Joseph H. Wicksteed, Blake's Vision of the Book of Job, with reproductions of the illustrations. A study (New York: Haskell House Publishers, Ltd., 1971), 33. The dates of these watercolors are a matter of deliberation among Blake scholars.
} 
Blake. ${ }^{102}$ The Illustrations of the Book of Job were completed in 1825 and published in 1826 , the year before Blake's death. ${ }^{103}$

Blake's fascination with the Old Testament figure of Job began early in his artistic career. As early as 1793 Blake produced a large engraving of Job, as well as a painting of Satan smiting Job with boils, which would be reused in the Illustrations of the Book of Job (Fig. 3). ${ }^{104}$ Despite the apparent fascination with the Old Testament personage, Blake was not satisfied with the Biblical portrayal of Job. Blake first mentions Job in The Marriage of Heaven and Hell, plate 5 (1790, Fig. 31), and the early mention in 1793 (Fig. 3) reveals the extent to which the Book of Job has already contributed to his thought. The God of Job, as mentioned in The Marriage of Heaven and Hell, was the living person who transcends reason; Job, Isaiah, and Ezekiel were all cited throughout the work in support of Blake's invocation of the Prophetic tradition of the Jews as opposed to the rationalism of the modern West and also, by implication, of the Classical philosophers. ${ }^{105}$ The story of Job was one that allowed Blake great philosophic freedom and of which Blake took full advantage. ${ }^{106}$ In his teachings, Swedenborg wrote nothing in reference to Job; in his Arcana coelestia (1749) he commented on Genesis and Exodus only in that he interpreted symbolic “correspondences." Blake utilized Swedenborg's correspondences not only in his prophetic book of Jerusalem, the Emanation of the Giant

\footnotetext{
102 David Bindman, Blake as an Artist, 208.

${ }^{103}$ S. Foster Damon, William Blake: His Philosophy and Symbols (Forge Village, Mass.: The Murray Printing Co., 1958), 223.

${ }^{104}$ The Philadelphia Museum of Art, William Blake 1751-1827. A descriptive catalogue of an exhibition of the works of William Blake selected from collection in the United States, 86.

${ }^{105}$ Kathleen Raine, The Human Face of God: William Blake and the Book of Job, 23.

${ }^{106}$ S. Foster Damon, William Blake: His Philosophy and Symbols, 223.
} 
Albion, but also when he considered and later executed the Illustrations of the Book of $J o b .{ }^{107}$

The Book of Job stands unique and alone, both in the Bible and in the world's literature. The Book of Job has elements of the epic, yet Job is no hero. The underlying theme of the Book of Job is suffering without the passions, hidden causes, and ultimate destruction as in the tragic tales of Greek epics like Homer's Odyssey. The subject is the confrontation between man and God. God is one focus and man is the other focus. At one focus is man in all his finiteness and struggle for the good life; at the other focus is God, designer, creator, and ruler of the cosmos. Where the two foci overlap, "religion" is found between the two. In the transition between these centers lie all the enigmatic questions about man's relation to God and in the universe. ${ }^{108}$

The Book of Job with forty-two chapters falls in the category of Wisdom books in the Old Testament. The book was originally written in a dialect of Hebrew. Except for a single allusion to the river Jordan, there is no reference in the book to any place in Palestine or to any event in Hebrew history. ${ }^{109}$ The first verse of the first chapter of the Book of Job gives only a cryptic clue as to the location in which Job lived as a place called Uz. There is no record in Hebrew history of such a place and theologians and scholars hypothesize Uz to be a reference to a place of the Edomites, the native nonHebrew people of Palestine.

The content of the Book of Job begins with a narrative introduction, and ends with a short conclusion of a similar character. The long poetic dialogue between the two

\footnotetext{
${ }^{107}$ Kathleen Raine, The Human Face of God: William Blake and the Book of Job, 16.

${ }^{108}$ Albion Roy King, The Problem of Evil: Christian Concepts and the Book of Job (New York: The Ronald Press Company, 1952), 19.

${ }^{109}$ Ibid., 21.
} 
narratives that makes up the greater part of the book is philosophical rather than narrative, and is an exalted protest against shallow solutions to the problem of suffering. Job loses his sons, his property, and nearly his faith during his suffering. Job's voices the opinion that if he suffers, it follows the he has sinned. Of course, this supposition is false: since according to Job (1:1) Job is described as "blameless and upright" and feared God and set his face against wrongdoing. Job protests the accusation of sin and is represented throughout the book as a man whose terrible misfortunes are in bewildering contrast to his spiritual suffering. In the end, Job is overwhelmed by Jehovah's power and in Job's humility, he repents. Job repents not for any moral failure to obey God's laws, only for his intellectual presumption in expecting to understand God's ways. God makes no charge of sin against Job and only corrects him of folly in aspiring to understand the mysterious ways of Heaven, which man could never truly understand. ${ }^{110}$ God leaves Job more prosperous than ever in the end of the book, but the problem of evil is left unsolved. The moral of the story, however, is clear: faith, not knowledge, is the secret to salvation. Blake was not satisfied with the Biblical evasion of the great world problem of evil and suffering. Blake deliberately exceeded the author of the Book of Job by giving the world an answer, which had been withheld in the Old Testament. ${ }^{111}$ Blake was an avowed system maker. "I must Create a system," he said, "or be enslav'd by another Man." 112 This system is developed from his earliest work to its complete form in Jerusalem, the Emanation of the Giant Albion and finally manifests itself as system

\footnotetext{
${ }^{110}$ Joseph H. Wicksteed, Blake's Vision of the Book of Job, with reproductions of the illustrations. A study, 34.

${ }_{111}^{11}$ S. Foster Damon, William Blake: His Philosophy and Symbols, 224.

${ }^{112}$ Joseph H. Wicksteed, Blake's Vision of the Book of Job, with reproductions of the illustrations. A study, 34.
} 
applicable to the Bible in the watercolors and prints to the Illustrations of the Book of Job.

Blake's answer was this: Job, living in accordance with the law of others, rather than by the instinct of his own heart, had left himself open to the inroads of Satan. Job had relied upon a moral code for his happiness, not realizing that the unassailable happiness comes from a sacrifice of self (Fig. 34). This knowledge is revealed during the inevitable passage through the state of "Experience." The catastrophes poured upon Job by Satan really spring from Job's own false notions of virtue; and as long as Job was selfsatisfied, he would be afflicted by these unexpected turns of "fate," a fate which he himself invoked upon others and which recoil upon himself eventually. But his troubles force Job to look inward, into his own soul. When Blake's Job analyzes his own soul he not only recognizes and drives out the error in is life, he sees Divinity itself; and after such a vision, nothing more can trouble him. ${ }^{113}$ As a human, Job belongs to the race of Adam and is therefore fallen. Blake illustrates this fallen state in his work Elohim Creating Adam from 1795 as example of Blake's belief that all men are fallen due to their intellect overwhelming their imagination (Fig. 32). To Blake, Job was a man of intellect and he has allowed his mind to separate itself from his spirit. This divorce between inward and outward in Blake's interpretation can be called a spectrous misconception in which the materiality of the outside world can give accurate information about Job's spiritual, or internal condition. To Blake, Job is doubly fallen in that he has allowed reason to triumph over imagination, leading to his suffering. ${ }^{114}$

\footnotetext{
113 S. Foster Damon, William Blake: His Philosophy and Symbols, 224.

${ }^{114}$ Andrew Wright, Blake's Job: A Commentary, xxi.
} 


\section{The Illustrations}

The watercolors and prints of the Illustrations of the Book of Job provide insight into Blake's unique interpretation. In this chapter, the watercolors and specific prints will be analyzed with particular detail to further discovering the system in which Blake chose to solve the problem of evil and human suffering. To begin consideration of Blake's work, the title page of the 1826 print series will be analyzed (Fig. 33).

Blake proclaims his independence from the Eighteenth Century in the anticlassical lettering on the title page: the Hebrew letter which read 'Book of Job' and the Gothic letters of the title in English are both, by their very design, quite unique and atypical of the period in which the print was executed. Seven angels are portrayed in an arc below the lettering. The number of the angels is significant for the number seven represents the seven eyes of God or the seven angels of the Apocalypse. ${ }^{115}$ The title page of the twenty-one prints establishes the theme of the Illustrations of the Book of Job with the inclusion of the seven angels and the Hebrew inscription alluding to the mysteries that Blake set out to solve with his interpretation of the Book of Job.

In the watercolor series, the first painting is of Job, wife, and his family under a majestic oak tree (Fig. 34). The family is praying, all showing serene expressions on their faces. The family prayers rest upon Job's lap in books written by others and musical

\footnotetext{
${ }^{115}$ S. Foster Damon, William Blake: His Philosophy and Symbols, 225.
} 
instruments of spontaneous praise hang silent upon the tree above Job and his family. The family is in the state of 'Innocence,' according to Blake, unaware of the doom and suffering about to befall them. But in Blake's watercolor and print, Job's error is clear: he relies upon 'the Letter Killeth,' and not upon his own inward promptings and instincts. In the background of both the watercolor and print, a "Gothic Church" is rendered to the right of Job's family and the viewer's left of the picture. Blake had utilized a symbolic technique of placing significance on objects depicted on the "stage" right or "stage" left of the picture. From the earliest Christian time, the right has been synonymous with the holy, and the left by the derivation of the word itself with the sinister. But with the rendering of a Gothic church, Blake takes his symbolism farther. The Gothic Church denotes the true Church while in later prints a Druid structure denotes the Church's opponent, Moral Law. ${ }^{116}$ As mentioned in Chapter One, Blake believed that the Druids were the natural opponent of the Christian Law. In the Butts watercolor, the Lord's Prayer is inscribed upon the face of the setting sun while in the prints, the prayer is above the image of Job and his family.

The importance of the marginal texts in the prints can only be perceived within the context of Blake's knowledge of the Old and New Testaments (Fig. 52). Many of the passages in the margins of the prints are from the Book of Job itself while many are not. The significance of the marginal texts only strengthens Blake's system to which he would solve the problem of Job's suffering, relying on Old Testament prophecy of the Messiah and the fulfillment of that prophecy by quoting from the New Testament. ${ }^{117}$ The first image of the series is filled with visual allusions to the Old and New Testaments and to a

\footnotetext{
${ }^{116}$ Ibid., 225-6.

${ }^{117}$ Andrew Wright, Blake's Job: A Commentary, xvii.
} 
viewer unfamiliar with the intricacy of Biblical texts, the meaning of Blake's work can be daunting. However, the overall theme of the first print is clear, the theme of innocence and perfection, thus giving the reader and viewer a starting point in which to consider the misfortunes that would quickly follow in the Book of Job.

The second image in the series is simply called "Satan before the Throne of God" (Fig. 35). Job sits with his wife at the bottom of the picture, each grasping a book of prayer, one opened, and one closed; in his heart he feels that something is amiss. Meanwhile, above Job, in the heavens, the youthful nude figure of Satan appears before the aged figure of God enthroned. It is interesting to note that the figure of Job clearly resembles that of the figure of God, alluding to the passage in Genesis where Man is made from God's image. ${ }^{118}$ However, with the entrance of Satan before the throne of God, the accusation of Job begins. As depicted in Job (1:6-7), Satan has been back and forth across the face of the Earth. The debate begins with God asking Satan whether the fallen angel had considered his servant Job in Satan's wanderings and with this debate, Innocence turns to Experience as echoed in Blake's earlier works and religious beliefs.

The third image is the result of God and Satan's agreement and the beginning of Job's suffering. "The Destruction of Job's Sons" (Fig. 36) portrays the destruction of Job's family as a satanic challenge of faith. Above, the bat-winged and spiteful Satan rains down fire to destroy the home of Job's sons, killing all in a dramatic gesture. The futile pose of Job's central son, reaching down to his wives and daughters while holding his child on his shoulder he has a countenance of the resigned acceptance of death, juxtaposing the evil countenance of Satan from above the destruction. Fire, and the falling of the Classical architectural elements of the home in which Job's sons lived

${ }^{118}$ Ibid., 11. 
represents a house of pleasure by Blake's rendering of the ruin. What is the cause of the destruction of Job's sons? To Blake, the ruin springs from Job's invisible curse of his ideas and moral conduct or his inability to see inward. The pendulum of suffering strikes Job the hardest with the death of his progeny. ${ }^{119}$ This passage by Blake is not illustrated in the Bible, thus alluding to the imaginings of Job as he hears the news of his sons' death in the succeeding print.

The fourth image, "The Messengers tell Job of the Misfortunes that have Befallen him" (Fig. 37), is a clear interpretation of the Biblical passage of Job (1:14-15). Job and his wife are distraught, his wife throws up her hands in despair and shock, and Job, the pious yet misled man, clasps his hands in prayer, his eyes raised to the heavens. With the news of the disaster, Satan enters even deeper into Job's soul, despite his prayer. Job's faith is still present in his false God or the God representing only Moral Law to Job, for he does not yet understand the true cause of the disaster- himself. $^{120}$

While "Satan going forth from the Presence of the Lord" (Fig. 38) is not part of the Bible, it is a passage clearly made to fit Blake's system. Job and his wife sit dejectedly; their bodies slumped, on a Druidic bench or altar. Job gives half a loaf of bread to a poor man to his left. However, Job does not yet realize mere giving is not tantamount to true piety. Behind Job, Druidic structures have replaced the Gothic Church showing that Job is clearly in error. ${ }^{121}$ The Druidic architecture is symbolic of the primal, brutal religion of Moral Law, which sacrifices others, but not the Self. Above Job and his wife, Blake depicted God enthroned. Satan reaches down from the heavens to pour a vial near to Job's ear, which contains spiritual poison; by this, Blake illustrates Satan's

\footnotetext{
${ }^{119}$ S. Damon Foster, William Blake: His Philosophy and Symbols, 227.

${ }^{120}$ Ibid., 227.

${ }^{121}$ Andrew Wright, Blake's Job: A Commentary, 19.
} 
faltering confidence in his capacity to corrupt Job. God appears too mournful and old to deal with the young Satan for God is disappointed in his servant Job.

"Satan smiting Job with Boils" (Fig. 39) comes from the earlier painting by Blake (Fig. 3). This passage presents the strongest image of Job's suffering. In the earlier painting Satan was depicted with wings, his mouth screwed shut as he pours disease on Job as Satan stood upon his body. In the watercolors and prints, Satan is depicted without wings and has a joyful expression on his face. Satan is young, strong, and virile with clearly visible genitals. Now Job's errors have manifested physically. Job's God has become devilish, and the boils are the most painful and physical fact of all. ${ }^{122}$ Four arrows coming from Satan's right hand symbolize the death of four senses: sight, hearing, taste and smell; Blake thus places Job in a true state of the limitations of "Experience" as opposed to his state of "Innocence" in the first image.

Job writhes on the ground, his hands and fingers stretched out, his mouth agape and his eyes averted from the fiery contents of Satan's vial. Job's feet rest upon the knees of his grieving wife who is still his companion through the trials Job brought upon himself. By placing Job's wife at his feet, Blake refers back to Jerusalem, the Emanation of the Giant Albion and “Albion's Sleep” (Fig. 27). Job's wife is included during Job's trials because Blake's belief was a man and his mate are literally one spirit, divided into two bodies during Adam's sleep in the Garden of Eden, therefore as Job suffers, so does his wife. ${ }^{123}$ With the impairment of Job's senses he will not see the sun or the light of God. The sun does not appear in the later watercolors and prints until the very end. He is

\footnotetext{
${ }^{122}$ Ibid., 21.

${ }^{123}$ S. Foster Damon, William Blake: His Philosophy and Symbols, 226.
} 
separated from his wife with his Experience, although she remains with him through the rest of Blake's interpretation.

“Job's Comforters" (Fig. 40) has a connection to Blake's Jerusalem, the Emanation of the Giant Albion in which Blake wrote: "Corporeal friends are spiritual enemies." The friends with their insulting benevolence bring cold comfort to Job and his wife by telling Job that if his god would afflict him with such suffering, it would be better to abandon his god. In the Biblical Book of Job, his wife, not Job's literal and spiritual mate as she is depicted by Blake, tells Job to "Curse God, and die." ${ }^{124}$ Blake, the system maker, disliked this passage, and simply omits it from his interpretation. However, the false comforters remain for several more passages.

“Job's Despair" (Fig. 41) is the visual outlet of Job's grief where he lifts his hands in despair, cursing the day he was born in the passage, "Let the Day perish where in I was Born," accentuates the print and is only an visual allusion in the watercolor. However, as Job curses, he will not curse his God. Tears run down Job's face as he laments, his wife and comforters cannot bear to face Job in such torment. Job is isolated by his grief and by his own devices. ${ }^{125}$ This terrible image depicts Job's suffering as man in ultimate isolation with no angels near, as God has seemingly disappeared from Job's thoughts.

“The Vision of Eliphaz" (Fig. 42) is a condensed version of the long argument of Job's friends as they gesture to an imagined image above. Eliphaz the Temanite gestures to a scene where Eliphaz sees an image of God from his bed. In this story, Eliphaz rebukes Job of the blasphemy of putting himself above God. Two false friends watch the

\footnotetext{
${ }^{124}$ Andrew Wright, Blake's Job: A Commentary, 23.

125 Ibid., 25.
} 
above scene in terrified piety. ${ }^{126}$ The truth of Eliphaz's rebuke strikes Job so deeply that he is depicted with a stricken look upon his face, and the stiffening awe of his body. Eliphaz's God resembles the speaker and not Job, introducing the idea that God resembles each and every man, thus to think that God resembles one man alone is folly. With Eliphaz's vision, Job is only beginning to realize the reason for his trials.

"Job rebuked by his Friends" (Fig. 43) is one work in which Job asks for pity from God and his family. He realizes that his first sin was the admission of Satan into his mind. Job's friends accuse him with self-righteous countenances, pointing fingers at him. Job's tears run freely down his face while his wife cries in incomprehension and despair. Job's wife is not immune in her grief as she hugs her knees. Her pose is reminiscent of several figures throughout Blake's work, most notable of a winged figure from the frontispiece of America, a Prophecy (1793, Fig. 44).

Being so harshly accused, Job turns to God for comfort and justification. Job's body is, majestic, having endured the trials of Satan. However the body may have hardened, the spirit is still weak. The result is the next image, which demonstrates a terrible revelation. $^{127}$

“Job’s Evil Dreams" (Fig. 45) is demonstrative of Job's extreme agony, marked by self-knowledge and terrible isolation. ${ }^{128}$ The God in Job's dream is similar to Eliphaz's God, which is a God of Justice since he points to the stone tablets of the Law. This God is reminiscent of Urizen in Blake's earlier works. Job lies upon his back, his skin pocked with boils; his hands raised palms up as to fend off the god above him who is

\footnotetext{
${ }^{126}$ S. Foster Damon, William Blake: His Philosophy and Symbols, 229.

${ }^{127}$ Ibid., 229.

${ }^{128}$ Andrew Wright, Blake's Job: A Commentary, 31.
} 
false, wrapped in the serpent of Materialism and has cloven hooves for feet. ${ }^{129}$ This image is very similar to Blake's Elohim Creating Adam (Fig. 32); however, this God of Justice is only Satan in disguise, and this guise is accentuated by the gripping of Job's legs and body by demons that issue from a fiery pit below Job's bed. Fire and lightening move all around Job and the false god. There is no salvation from the false god above, and below are hellish demons. Job turns his head away in fear and the agony of acknowledging his sin, from which there is no escape. This image represents visually Blake's most insistent doctrine. The true God is not this evil and temporary god of Justice, but Jesus, the Imagination, who forgives all sins and requires no penalty. The sinner is already punished in the very act of his sin. Understanding, which is forgiveness, is the true Savior. ${ }^{130}$ Job has yet to realize this doctrine fully of God as benevolent and multi-faceted as in the way of the New Testament idea of the Trinity, but he is beginning on his way with the realization of his $\sin$.

"The Wrath of Elihu" (Fig. 46) is a passage in which the young newcomer is angry with Job. Elihu does not pretend to be a friend of Job; therefore, he is not hypocritical like Job's false friends. Blake commented on friendship by saying "A man may be the friend of my spiritual life while he seems the enemy of my corporeal, though not the vice versa." ${ }^{131}$ Elihu rebukes Job's false friends passionately with a fierce countenance, but the false friends do not hear the words of the young for their faces are passive and their eyes glazed. Elihu is a man at the beginning of the path of Experience but in his youthful inexperience, closer to Innocence, Elihu can clearly see what is right and what is wrong. Elihu points to the stars, which represent the mechanism of the

\footnotetext{
${ }^{129}$ S. Foster Damon, William Blake: His Philosophy and Symbols, 230.

${ }^{130}$ Ibid., 230.

${ }^{131}$ Ibid., 230.
} 
universe, the order which rules all things and rebukes Job for going against the heavens. Job listens to the young man's words, hugging himself while feeling the truth of Elihu's words. Again, Job's wife is curled in on herself, a gesture seen previously in "Job rebuked by his Friends (Fig. 43)."

"The Lord answering Job out of the Whirlwind" (Fig. 47) is the climax of Blake's retelling of the Book of Job. God descends in the mystical tempest to this world, passing into the temporal sphere from the infinite realm of the heavens. This form of God's descent with arms outstretched is the eternal crucifixion later illustrated with the coming of Christ. In the coming of Christ, God becomes "as we are" descending into the world of matter for the salvation of man. This God is the true God, for Blake shows his right foot as proof in the print (Fig. 48) as compared to the cloven-hoofed Satan masquerading as God in "Job's Evil Dream (Fig. 45). ${ }^{132}$ As God appears, the false friends bow their bodies in fear, while Job and his wife are again side by side, their hands clasped in prayer and in awe. This passage is where God, the god that Job thought he had believed in, manifests himself to Job in order to teach Job the correct path in Experience. God pays no attention to the false friends, his attention fixed on his creation, Job, his hand over Job's head. God's form and whirlwind comprised over half of the scene, but Blake still manages to depict the Druidic structure in the far left, indicating that Job is not yet ready for the truth and love of God.

"The Creation" or "When the Morning Stars Sang Together" (Fig. 49) is the moment of mystical vision, and departs from the Biblical Book of Job in Blake's interpretation. Blake digresses to the creation to further strengthen his system of myth. Above Job, his wife, and his company, God is shown at Creation, forming the stars,

\footnotetext{
${ }^{132}$ Ibid., 231.
} 
calling forth light from darkness and being praised by the angels for such a glorious event. Blake employs traditional mythological elements to physically represent the light and darkness. These representations are perhaps the only reference to Greco-Roman mythology in any of Blake's work considered so far. Light or dawn, is represented by Apollo's four horses and chariots bringing the sun. In opposition to the light is the darkness and the moon of Selene. Instead of a chariot pulled by horses or oxen, Blake substitutes serpents. The scene is separated quite logically, Job and company on the bottom or terrestrial realm, God in the mid-point of the sky and deeper heavens with representations of light and dark, while above are the angels and the distant stars. This image is perhaps one of Blake's most magnificent creations as it was one of the most popular images by Blake and allowed the artist's work be known after his death. ${ }^{133}$ "Behemoth and Leviathan" (Fig. 50) is a continuation of the vision. God leans forward upon a cloud pointing to a globe or the circle of destiny itself while Job and company look. ${ }^{134}$ God explains why he created the material world, which included Behemoth "chief of the ways of God," and Leviathan "King over the Children of Pride," as the fearful symmetry of the one inescapably related to the materiality of the other. These creatures of God's mystery are unseen by man, representative of God's power of creation. The behemoth is a hideous creature, resembling a hybrid of rhinoceros, elephant, and large cat with long fangs. The leviathan is just as terrible: a sea dragon of mythical proportion with defined scales and rows of razor-like teeth. Even these

\footnotetext{
${ }^{133}$ Ibid., 231.

${ }^{134}$ Andrew Wright, Blake’s Job: A Commentary, 39.
} 
terrifying creatures have been "made," and are seen to be in alliance as the doors of perception are opened for Job. ${ }^{135}$

The sixteenth image, "The Fall of Satan" (Fig. 51) is commented on as "Whenever an Error is recognized — given bodily form — and rejected forever, a 'Last Judgment' takes place." Satan's fall from Heaven is the most dramatic moment of the scheme of salvation. ${ }^{136}$ Satan and his minions are cast out of Heaven and thrown down in violent lightning and pain into the flames of Hell as Job and his wife watch, and the false friends recoil in horror and fear. The flame in which Satan is encapsulated represents the evil heart, which Job casts out. ${ }^{137}$ God's light is bright again, and in it have appeared the spirits of pity and forgiveness. The Last Judgment in this image does two things: it pierces the clouds between the worlds of infinite and finite and it opens a gulf, showing the difference, between Job and his false friends. ${ }^{138}$ This gulf between Job and his false friends began with the previous work "Behemoth and Leviathan." Finally, Job is moving toward understanding and piety with the separation of him and his wife from the false friends in "The Fall of Satan."

In "The Vision of God," (Fig. 52) God appears before Job and his wife, his light falling upon the couple as they kneel in love and reverence. At last, fear and awe of God have turned to love compared to Job and his wife's posture in "The Lord answering Job out of a Whirlwind (Fig. 47)." Behind Job, his false friends bow their heads in shame and fear. Blake significantly altered the print (Fig. 53) with the false friends turned away in fear, and covered in the darkness of night. The false friends are beyond the power of the

\footnotetext{
${ }^{135}$ Andrew Wright, Blake's Job: A Commentary, 39.

${ }^{136}$ S. Foster Damon, William Blake: His Philosophy and Symbols, 233.

137 Andrew Wright, Blake's Job: A Commentary, 41.

${ }^{138}$ S. Foster Damon, William Blake: His Philosophy and Symbols, 233.
} 
vision and have therefore turned away from God. ${ }^{139}$ However, in both the print and watercolor, God's hand is above the heads of Job and his wife, engaging them directly in blessing.

"Job’s Sacrifice" (Fig. 54) immediate follows "The Vision of God," in which Job has learned to see. God has now withdrawn from Job to Heaven, and Job is a changed man ready to worship God with true faith and piety. In the watercolor, Job stands before a burning altar, facing the viewer while Job's wife, to his right, and his friends kneel to his left kneel in prayer. In the print, Job is facing the altar but the configuration of the auxiliary figures is the same. The cruciform position of Job's arms in both print and watercolor suggest at once his new knowledge and willingness to sacrifice even himself for the friends who became his enemies. ${ }^{140}$ Job's strength has returned at this point and his stands as a changed man with a face that portrays a haunting countenance due to his visions. His experience with God has left a mark on Job, and Blake conveys this mark by depicting Job almost as God is depicted in the previous passages.

"Job Accepting Charity" (Fig. 55) is the resolution of the tableau in "Satan going forth from the Presence of the Lord" (Fig. 38). Now Job and his wife have learned the true meaning of charity. They can accept charity humbly because they have achieved the humility that follows upon the emptying of selfhood that is prerequisite to the achievement of genuine sympathy. The charity in the fifth image was false because it was patronizing, and, in fact, defensive rather than the expression of brotherly love. ${ }^{141}$ Job and his wife are depicted in a pose that denotes humility, his wife smiling demurely as

\footnotetext{
${ }^{139}$ Andrew Wright, Blake's Job: A Commentary, 43.

${ }^{140}$ Ibid., 45.

141 Ibid., 47.
} 
she averts her eyes from the neighbors. These new friends are true friends, for their charity is not wrought of self-importance as it had been with Job's false friends.

"Job and his Daughters" (Fig. 56) is another departure from the Biblical interpretation of the Book of Job. In this passage by Blake, Job tells his daughters the story of his life while he gestures with his arms raised to the stirring and ever moving heavens. Placed in a pastoral setting, the images of Job's life are shown in whirls of vision or in the rondelles in the print version (Fig. 57). The three daughters represent Poetry, Painting, and Music, who had vanished during the period of Job's trials. The production of Art, according to Blake, is the giving of one's self and therefore the human equivalent of the Divine Sacrifice. ${ }^{142}$

The final image "Job and his Wife restored to Prosperity" (Fig. 58) is the counterpart to the first image "Job and his family (Fig. 34)," however it is different in the sense that the last image is the result of Experience and not Innocence. With this image, the story of Job ends, codices of song replace the books of Law and the instruments that were disregarded are taken up. By making music and giving praise, Job and his family have relied on their inward souls to follow the Law instead of the books written by others. In the watercolor, the sun is once again inserted, but in this image with reference to Revelation (15:3): “And they sing the song of Moses, the servants of God, and the song of the lamb saying Great and Magnificent are thy Works Lord God Almighty, Just and True are thy ways thou King of Saints."

\footnotetext{
${ }^{142}$ S. Foster Damon, William Blake: His Philosophy and Symbols, 235.
} 


\section{Blake's Answer}

The story of Job reveals how Blake's system has ingeniously answered the question of evil and suffering. One must look inward to the soul and follow one's heart in order to be close to God. Following the Moral Law alone will not lead to salvation, and faith in good acts is not enough, we must examine the soul and search for God relying on self-sacrifice to attain grace. Blake's unique interpretation of the Book of Job utilizes both Testaments of the Bible and participates in a traditional exegesis, leading us not to consider Job's story as separate from that of the life of Jesus. To Blake, man was a cog in the dreadful, increasing materialism of the world and the death of the spirit by relying upon the Moral Law. Job was similarly caught in the world of laws and rationality, but was finally free by his belief in the spiritualistic and artistic nature of salvation. ${ }^{143}$

This answer was formulated by Blake via the creation and synthesis of his personal system. Blake's system is not simply one of myth, but also of belief. In creating this system, Blake was able to articulate his body of works in a comprehensible manner, which was appealing to scholars of the spirit and mysticism. The Illustrations of the Book of Job was Blake's true test, by using his system to retell the ancient tale of Job. God, Satan, and Job were part of Blake's created pantheon, each character corresponding in several ways to his invented characters. Using the characters and symbols of his earlier Prophetic Books, Blake was able to overcome suffering by using Job as a model. Therefore, The Illustrations of the Book of Job is not a simple artistic retelling of the

\footnotetext{
${ }^{143}$ Malcolm Cormack, William Blake: Illustrations of the Book of Job, vii.
} 
book, but a work that has deeper implications to Blake and to those who study Blake's system of mythology. 


\section{$\underline{\text { Conclusion }}$}

William Blake has been considered eccentric since he began producing artwork with James Basire in 1772. The originality, interconnectedness, and complexity of Blake's work and system may be daunting. This thesis has barely scratched the surface regarding Blake's complete body of work. With investigations into such masterpieces as Jerusalem, the Emanation of the Giant Albion and The Illustrations of the Book of Job, one can begin following the path William Blake took to create his works. Emphasis on deciphering Blake's views of such figures as Isaac Newton, Emanual Swedenborg, and concepts of rational science, mysticism, British legend with Druidic elements, Hindu symbolism, and biblical lore have enabled readers of this thesis to understand Blake's system of artificial mythology.

The artificial mythology Blake employed to create his works provided a precursory model for modern writers. However, as I have demonstrated, Blake created his system not only in words, but in image as well. The goal in understanding Blake's system is to explain one of the fundamental questions of humanity: why human beings 
must suffer in this life. To construct such a system is ambitious, but Blake believed in his system and used it in every work he created.

With this thesis, three essential points have been established. First, William Blake was an avowed systematizer, writing, "I must Create a System or be enslav'd by another Man's, I will not Reason \& Compare: my business is to Create." ${ }^{144}$ In being a systematizer, Blake has many ideals in common with his supposed antithesis, Isaac Newton. Second, William Blake used the systems of lore, myth, and religion to construct a new system. Third, William Blake borrowed visual configurations of mythological and religious subjects to convey understanding through his vision. In appropriating the image of Brahma springing from the navel of Vishnu, or assigning a new meaning to the figure of the Druid, William Blake intended to make his system universally comprehensible.

William Blake's system, however, has not been universally comprehended by his readers. It was obscure even in its own time in the late Eighteenth Century and into the early Nineteenth Century. This obscurity was due in part to Blake's personality and behavior. Biographers have painted Blake as a man whose interests ran to the mystical and, perhaps, extreme heterodox. ${ }^{145}$ One of the motivations for this thesis is that modern scholars often find interpreting Blake's poetry and artwork difficult. This difficulty derives from Blake's idiosyncratic visual vocabulary. He makes use of an obscure vernacular language, the meanings of which have been lost following the industrialization of Europe. Blake did not leave his audience a simple lexicon to interpret his text and

\footnotetext{
${ }^{144}$ An excerpt from Jerusalem the Emanation of the Giant Albion, plate 10, lines 21 through 22.

${ }^{145}$ Early Blake biographers included Edwin Ellis, Alexander Gilchrist, Basil de Selincourt, and G. K. Chesterton. Analysis into Blake's work included essays by Algernon Swinbourne in 1868, and anthologies of Blake's work compiled by William Michael Rossetti in 1874.
} 
imagery. As S. Foster Damon wrote in the introduction to A Blake Dictionary: The Ideas and Symbols of William Blake:

The purpose of this dictionary is to make things easier for his [Blake] readers by gathering together the clues scattered through his writings. These gatherings most often have shed welcome light. At other times, when the meaning has not made itself clear, I have at least laid out the material for future scholars. ${ }^{146}$

Damon, whose research has been used extensively throughout this thesis, was the first to begin to outline Blake's myriad symbols and sources. Nonetheless, Blake continues to confound and intrigue even the greatest scholars.

The mysticism and difficult vernacular language surrounding Blake's work can be dispelled through an understanding of the world in which Blake lived, and the influences that helped Blake shape his system. This non-conforming system adhered to no prescribed religious doctrine of the churches or dogmas of other sects active during Blake's lifetime. In many ways, Blake's system is a true "Christian" fantasy, refuting the constraints of Rationalism and the perils of Deism and Atheism. Eccentricities aside, Blake was a self-proclaimed spiritual man. As a simple "follower of Christ," Blake embraced other world religious traditions to further solidify his system of artificial myth. William Blake was a "Mental Traveller." ${ }^{47}$ S. Foster Damon continued in his Introduction, saying:

So profound were his researches in the terra incognita that he may be hailed as the Columbus of the psyche, in whose course Freud and Jung, among others were to follow. So novel was everything in this new world that no vocabulary was prepared for him. But these psychic forces were so real that he had to name them. Thence arose his special mythology, for these forces were living creatures...

\footnotetext{
${ }^{146}$ S. Foster. Damon, A Blake Dictionary, the ideas and symbols of William Blake, xxvii.

${ }^{147}$ 'The Mental Traveller' is a poem written by Blake, included in The Pickering Manuscript, 1803. This manuscript also included the famous poem 'Auguries of Innocence.'
} 
Blake is a challenge to every thinking person. He was so far ahead of his time that we are just catching up to him. ${ }^{148}$

Blake was not simply compelled to name these "psychic forces," but to illustrate them as well. Blake's work cannot be understood by reading the text alone. For example, in its original context, Jerusalem, the Emanation of the Giant Albion, was not meant to be read as text alone. Illustrations weave about the text, entangling Blake's words with visual representations of his artificial mythology.

In closing, William Blake's artificial mythology will continue to inspire scholars, and baffle most others. One-hundred and eighty years after his death, artists and scholars are still trying to comprehend William Blake. This thesis has demonstrated that Blake set a new precedent in the arts with the combination of text and picture. The influence of Blake's art finally became apparent in the Mid-nineteenth century with Pre-Raphaelite artist Dante Gabriel Rossetti (1828-1882) who also interlinked text or poetry with art in “Anima" (Fig. 59). ${ }^{149}$ From the point of view of design, Blake's art transcended movements in art like that of the Pre-Raphaelites which begun to develop during the latter part of Blake's lifetime, and anticipated artwork with emphases on individual imagination. ${ }^{150}$

Art historians have come closer to engaging with Blake's complex narrative through his visual work. William Blake was not an "eccentric," but a "visionary." However, by the very nature of Blake's system, one can see that Imagination is the

\footnotetext{
${ }^{148}$ Ibid., xxviii, xxv.

${ }^{149}$ Malcolm Cormack, William Blake: Illustrations of the Book of Job, vi. J. C. E. Bassalik-de Vries, William Blake in his relation to Dante Gabriel Rossetti (Basel: Buchruckerei Brin \& Cie., 1911). Dante Gabriel Rossetti and his brother William Michael Rossetti were familiar with Blake's work. W. M. Rossetti edited an edition of Blake's poetry, Poetical Works of William Blake, 1874.

${ }^{150}$ Robert L. Delevoy, Symbolists and Symbolism (New York, NY: Rizzoli International Publications, Inc., 1978).
} 
ultimate state of oneness with the universe or God. Blake's Job is "everyman" and to Blake, “everyman” was God as seen in The Illustrations of the Book of Job, "The Vision of Eliphaz" (Fig. 42). By employing Imagination alone, each reader can be a step closer to understanding Blake's system. 


\section{Bibliography}

Ackroyd, Peter. Blake, a biography. New York: Alfred A. Knopf Publishers, 1996.

Adlard, John. The Sports of Cruelty: Fairies, folksongs, charms and other country materials in the work of William Blake. London: C. \& A. Woolf, 1972.

Altizer, Thomas J. J. The New Apocalypse: the radical Christian vision of William Blake. Aurora, CO: The Davies Group, Publishers, 1967.

Ansari, Asloob Ahmad. "Blake and the Kabbalah." In William Blake: Essays for S. Foster Damon, edited by Alvin H. Rosenfeld. Providence, RI: Brown University Press, 1969.

Aubrey, Bryan. Watchmen of Eternity: Blake's Debt to Jacob Boehme. Lanham, MD: University of Press of American, Inc., 1986.

Archer, Mildred and Ronald Lightbown. India Observed: India as viewed by British Artists 1760-1860. London: Victoria and Albert Museum, Trefoil Books, 1982.

Bassalik-de Vries, J. C. E. William Blake in his relation to Dante Gabriel Rossetti. Basel: Buchruckerei Brin \& Cie., 1911.

Bearce, George D. British Attitudes Towards India 1784-1858. Oxford: Oxford University Press, 1961.

Bellin, Harvey F. “Opposition is True Friendship': Emanuel Swedenborg and his influences on Blake. In Blake and Swedenborg: Opposition is True Friendship, an anthology, the sources of William Blake's art in the writings of Emmanuel Swedenborg, edited by Harvey F. Bellin and Darrell Ruhl. New York: Swedenborg Foundation, Inc., 1985.

Bentley, G. E. Jr., ed. William Blake: the Critical Heritage. London: Routledge Kegan Paul, Ltd., 1975.

Bindman, David. Blake as an Artist. Oxford: Phiadon Press Ltd., 1977.

Blunt, Anthony. The Art of William Blake. Morningside Heights, NY: Columbia University Press, 1959. 
Bullen, J. B., ed. The Sun is God: Painting, Literature and Mythology in the Nineteenth Century. Oxford: Clarendon Press, 1989.

Burke, Joseph. "The Eidetic and the Borrowed Image: An Interpretation of Blake's Theory and Practice of Art." In The Visionary Hand: Essays for the study of William Blake's art and aesthetics, edited by Robert N. Essick. Los Angeles: Hennessey \& Ingalls, Inc., 1973.

Cormack, Malcolm. William Blake: Illustrations to the Book of Job. Richmond, VA: Virginia Museum of Fine Art, 1997.

Damon, S. Foster. A Blake Dictionary, the ideas and symbols of William Blake. Hanover, NH: University Press of New England, 1988.

Damon, S. Foster. William Blake: His philosophy and symbols. Forge Valley, MA: The Murray Printing, Co., 1958.

Damrosch, Leopold, Jr. Symbol and Truth in Blake's Myth. Princeton, NJ: Princeton University Press, 1980.

Damrosch, Leopold, Jr. “The Problem of Dualism.” In William Blake’s The Marriage of Heaven and Hell, edited by Harold Bloom. New York: Chelsea House Publishers, 1987.

Davies, J. G. The Theology of William Blake. New York, NY: Archon Books, 1966.

Delevoy, Robert L. Symbolists and Symbolism. New York, NY: Rizzoli International Publications, Inc., 1978.

Dobbs, Brian and Judy. Dante Gabriel Rossetti: An Alien Victorian. London: Macdonald and Jane's Publishers Limited, 1977.

Dole, George F. "Introduction." In Blake and Swedenborg: Opposition is True Friendship, an anthology, the sources of William Blake's art in the writings of Emanuel Swedenborg, edited by Harvey F. Bellin and Darrell Ruhl. New York: Swedenborg Foundation, Inc., 1985.

Doty, William G. Mythography, the Study of Myths and Rituals. University, AL: The University of Alabama Press, 1986.

Eaves, Morris, ed. The Cambridge Companion to William Blake. Cambridge: Cambridge University Press, 2003.

Eaves, Morris. William Blake's Theory of Art. Princeton, NJ: Princeton University Press, 1982. 
Edinger. Edward F. Encounter with Self: A Jungian Commentary on William Blake's Illustrations to the Book of Job. Toronto: Inner City Books, 1986.

Ellis, Edwin J. The Real Blake: A Portrait Biography. New York: McClure, Phillips and Co., 1907.

Erdman, David V. "Blake: the Historical Approach.” In Discussions of William Blake, edited by John E. Grant. Boston: D. C. Heath and Company, 1961.

Erdman, David V. The Illuminated Blake: All of William Blake's Illuminated Works with a Plate-by-Plate Commentary. Garden City, NY: Anchor Press, 1974.

Fisher, Peter F. "Blake and the Druids." In Discussions of William Blake, edited by John E. Grant. Boston: D. C. Heath and Company, 1961.

Frye, Northrop. "Blake's Treatment of the Archetype." In Discussions of William Blake, edited by John E. Grant. Boston: D. C. Heath and Company, 1961.

Frye, Northrop. Fearful Symmetry, a Study of William Blake. Princeton, NJ: Princeton University Press, 1947.

Frye, Northrop. "Poetry and Design in William Blake." In Discussions of William Blake, edited by John E. Grant. Boston: D. C. Heath and Company, 1961.

Gardner, Stanley. Blake. New York: ARCO Publishing Company, Inc., 1968.

Hall, Mary. Materialism and the Myths of Blake. New York: Garland Publishing, Inc., 1988.

Hammacher, A. M. trans. Langham, Tony and Peters, Plym. Phantoms of the Imagination: Fantasy and Literature from Blake to Dali. New York, NY: Harry Abrams Publishers, Inc., 1981.

Hill, Christopher. The World Turned Upside Down: Radical Ideas during the English Revolution. London: Penguin Group, 1972.

Hunt, Anthony. The Art of William Blake. Morning Heights, NY: Columbia University Press, 1959.

Johnson, Mary Lynn and Brian Wilkie. Blake's Four Zoas: the Design of a Dream. Cambridge, MA: Harvard University Press, 1978.

King, Albion Roy. The Problem of Evil: Christian Concepts and the Book of Job. New York: The Ronald Press Company, 1952. 
Kiralis, Karl. “Intellectual Symbolism in Blake's Later Prophetic Writings.” In Discussions of William Blake, edited by John E. Grant. Boston: D. C. Heath and Company, 1961.

Klonsky, Milton. William Blake: The Seer and His Visions. New York: Harmony Books, 1977.

Kostelanetz, Anne T. "Blake's 1795 Color Prints: An Interpretation.” In William Blake: Essays for S. Foster Damon, edited by Alvin H. Rosenfeld. Providence, RI: Brown University Press, 1969.

Lewis, Linda M. The Promethean Politics of Milton, Blake and Shelley. Columbia and London: University of Missouri Press, 1962.

Lieshout, Jules van. Within and Without Eternity: The Dynamics of Interaction of William Blake's Myth and Poetry. Amsterdam and Atlanta, GA: Rodopi, 1994.

Lincoln, Andrew. Spiritual History: A reading of William Blake's Vala or the Four Zoas. Oxford: Clarendon Press, 1995.

Lister, Raymond. The Paintings of William Blake. Cambridge: Cambridge University Press, 1986.

Lucie-Smith, Edward. Symbolist Art. London: Thames and Hudson Ltd., 1972.

Makdisi, Saree. William Blake and the Impossible History of the 1790s. Chicago: The University of Chicago Press, 2003.

Marshall, Peter. William Blake: Visionary Anarchist. London: Freedom Press, 1988.

Megroz, R. L. Dante Gabriel Rossetti: Painter Poet of Heaven in Earth. London: Faber \& Gwyer, 1926.

Moor, Edward, intro. Feldman, Burton. The Hindu Pantheon. New York, NY: Garland Publishing, Inc., 1984.

Nanavutty, Piloo. "Materia Prima in a Page of Blake's Vala." In William Blake: Essays for S. Foster Damon, edited by Alvin H. Rosenfeld. Providence, RI: Brown University Press, 1969.

Nanavutty, Piloo. "William Blake and Hindu Creation Myths." In The Divine Vision, Studies in Poetry and Art of William Blake born November 28, 1757, edited by Vivian De Sola Pinto. New York, NY: Haskell House Publishers, Ltd., 1968.

Noon, Patrick. The Human Form Divine. New Haven, Mass: Yale University Press, 1997. 
Ostriker, Alicia. "Desire Gratified and Ungratified: William Blake and Sexuality." In Essential Articles for the Study of William Blake, 1970-1984, edited by Nelson Hilton. Hamden, CT: Archon Book, 1986.

Ostriker, Alicia. Vision and Verse in William Blake. Madison and Milwaukee, WI: The University of Wisconsin Press, 1965.

Paley, Morton D. "'A New Heaven is Begun': Blake and Swedenborgianism." In Blake and Swedenborg: Opposition is True Friendship, an anthology, the sources of William Blake's art in the writings of Emanuel Swedenborg, edited by Harvey F. Bellin and Darrell Ruhl. New York: Swedenborg Foundation, Inc., 1985.

Paley, Morton D. William Blake. Oxford: Phiadon Press, 1978.

Philadelphia Museum of Art. William Blake, 1757-1827; a Descriptive Catalogue of an Exhibition of the works of William Blake Selected from Collections in the United States. Philadelphia, PA: Philadelphia Museum of Art, 1939.

Preston, Kerrison. Blake and Rossetti. London: Alexander Moring Limited, the De La More Press, 1944.

Raine, Kathleen. Blake and Antiquity. Princeton, NJ: Princeton University Press, 1977.

Raine, Kathleen. The Human Face of God: William Blake and the Book of Job. New York, NY: Thames and Hudson, 1982.

Raine, Kathleen. "The Swedenborgian Songs." In Blake and Swedenborg: Opposition is True Friendship, an anthology, the sources of William Blake's art in the writings of Emanuel Swedenborg, edited by Harvey F. Bellin and Darrell Ruhl. New York: Swedenborg Foundation, Inc., 1985.

Roe, Albert S. "The Thunder of Egypt." In William Blake: Essays for S. Foster Damon, edited by Alvin H. Rosenfeld. Providence, RI: Brown University Press, 1969.

Schorer, Mark. William Blake: the Politics of Vision. New York: Vintage Books, 1959.

Schuchard, Marsha Keith. Why Mrs. Blake Cried: William Blake and the Sexual Basis of Spiritual Vision. London: Random House-Century, 2006.

Schuchard, Marsha Keith. "Yeats and the 'Unknown Superiors': Swedenborg, Falk, and Cagliostro." In Secret Texts: the Literature of Secret Societies, edited by Marie Mulvey Roberts and Hugh Ormsby-Lennon. New York: AMS Press, 1995. 
Singh, Charu Sheel. The Chariot of Fire, a Study of William Blake in the light of Hindu Thought. Salzburg: Institut fur Anglistik und Amerikanistik, Universitat Salzburg, 1981.

Snart, Jason Allen. The Torn Book: Unreading William Blake’s Marginalia. Selinsgrove: Susquehanna University Press, 2006.

Sorensen, Peter J. William Blake's Recreation of Gnostic Myth: Resolving the Apparent Incongruities. Lewiston, NY: The Edwin Mellen Press, 1995.

Starobinski, Jean. Trans. Goldhammer, Arthur. Blessings in Disguise, or the Morality of Evil. Cambridge, MA: Harvard University Press, 1993.

Swinburne, Algernon Charles. William Blake, a Critical Essay. London: William Heinemann Ltd., 1925.

Townsend, Joyce H. William Blake, the Painter at Work. Princeton, NJ: Princeton University Press, 2003.

Viscomi, Joseph. Blake and the Idea of the Book. Princeton, NJ: Princeton University Press, 1993.

Weir, David. Brahma in the West: William Blake and the Oriental Renaissance. Albany, NY: State University of New York Press, 2003.

White, Helen C. The Mysticism of William Blake. New York: Russell \& Russell, Inc., 1964.

Whittaker, Jason. William Blake and the Myths of Britain. London: MacMillan Press Limited, 1999.

Wicksteed, Joseph H. Blake's Vision of the Book of Job, with reproductions of the illustrations. A study. New York: Haskell House Publishers, Ltd., 1971.

Wiebe, Paul M. Myth as Genre in British Romantic Poetry. New York: Peter Lang Publishing, Inc., 1999.

Wilkins, W. J. Hindu Mythology, Vedic and Puranic. $2^{\text {nd }}$ ed. London: Curzon Press, 1973.

Wingfield Digby, George Fredrick. Symbol and Image in William Blake. Oxford: Clarendon Press, 1957.

Wolf-Gumpold, Kaethe. William Blake: Painter, Poet, Visionary. London: Rudolf Steiner Press, 1969. 
Wright, Andrew. Blake's Job: A Commentary. Oxford: Clarendon Press, 1972.

Youngquist, Paul. Madness \& Blake’s Myth. University Park, PA: The Pennsylvania State University Press, 1989.

Zimmer, Heinrich. Ed. Campbell, Joseph. Myths and Symbols in Indian Art and Civilization. Princeton, NJ: Princeton University Press, 1974. 


\section{Appendix A}

\section{The Mental Traveller}

From the Pickering Manuscript, 1803

I travelled through a land of men, A land of men and women too, And heard and saw such dreadful things As cold earth wanderers never knew.

For there the babe is born in joy That was begotten in dire woe, Just as we reap in joy the fruit Which we in bitter tears did sow;

And if the babe is born a boy He's given to a woman old, Who nails him down upon a rock, Catches his shrieks in cups of gold.

She binds iron thorns around his head, And pierces both his hands and feet, And cuts his heart out of his side To make it feel both cold \& heat.

Her fingers number every nerve Just as a miser counts his gold; She lives upon his shrieks and criesAnd she grows young as he grows old,

Till he becomes a bleeding youth And she becomes a virgin bright; Then he rends up his manacles And pins her down for his delight. 
He plants himself in all her nerves

Just as a husbandman his mould, And she becomes his dwelling-place And garden, fruitful seventy fold.

An aged shadow soon he fades, Wandering round and earthly cot, Full filled all with gems and gold Which he by industry had got.

And these are the gems of the human soul:

The rubies and pearls of a lovesick eye, The countless gold of an aching heart,

The martyr's groan, and the lover's sigh.

They are his meat, they are his drink:

He feeds the beggar and the poor

And the wayfaring traveller;

For ever open is his door.

His grief is their eternal joy,

They make the roofs and walls to ring-

Till from the fire on the hearth

A little female babe does spring!

And she is all of solid fire

And gems and gold, that none his hand

Dares stretch to touch her baby form,

Or wrap her in his swaddling-band.

But she comes to the man she loves, If young or old, or rich or poor; They soon drive out the aged host, A beggar at another's door.

He wanders weeping far away Until some other take him in;

Oft blind and age-bent, sore distressed, Until he can a maiden win.

And to allay his freezing age

The poor man takes her in his arms:

The cottage fades before his sight, The garden and its lovely charms;

The guests are scattered through the land 
(For the eye altering, alters all); The senses roll themselves in fear, And the flat earth becomes a ball,

The stars, sun, moon, all shrink awayA desert vast without a bound, And nothing left to eat or drink And a dark desert all around.

The honey of her infant lips, The bread and wine of her sweet smile, The wild game of her roving eye Does him to infancy beguile.

For as he eats and drinks he grows Younger and younger every day; And on the desert wild they both Wander in terror and dismay.

Like the wild stag she flees away; Her fear plants many a thicket wild, While he pursues her night and day, By various arts of love beguiled.

By various arts of love and hate, Till the wide desert planted o'er With labyrinths of wayward love, Where roams the lion, wolf and boar,

Till he becomes a wayward babe And she a weeping woman old. Then many a lover wanders here, The sun and stars are nearer rolled,

The trees bring forth sweet ecstasy To all who in the desert roam, Till many a city there is built, And many a pleasant shepherd's home.

But when they find the frowning babe Terror strikes through the region wide; They cry, 'The Babe! the Babe is born!' And flee away on every side.

For who dare touch the frowning form His arm is withered to its root, 
Lions, boars, wolves, all howling flee

And every tree does shed its fruit;

And none can touch that frowning form,

Except it be a woman old;

She nails him down upon the rock,

And all is done as I have told. 


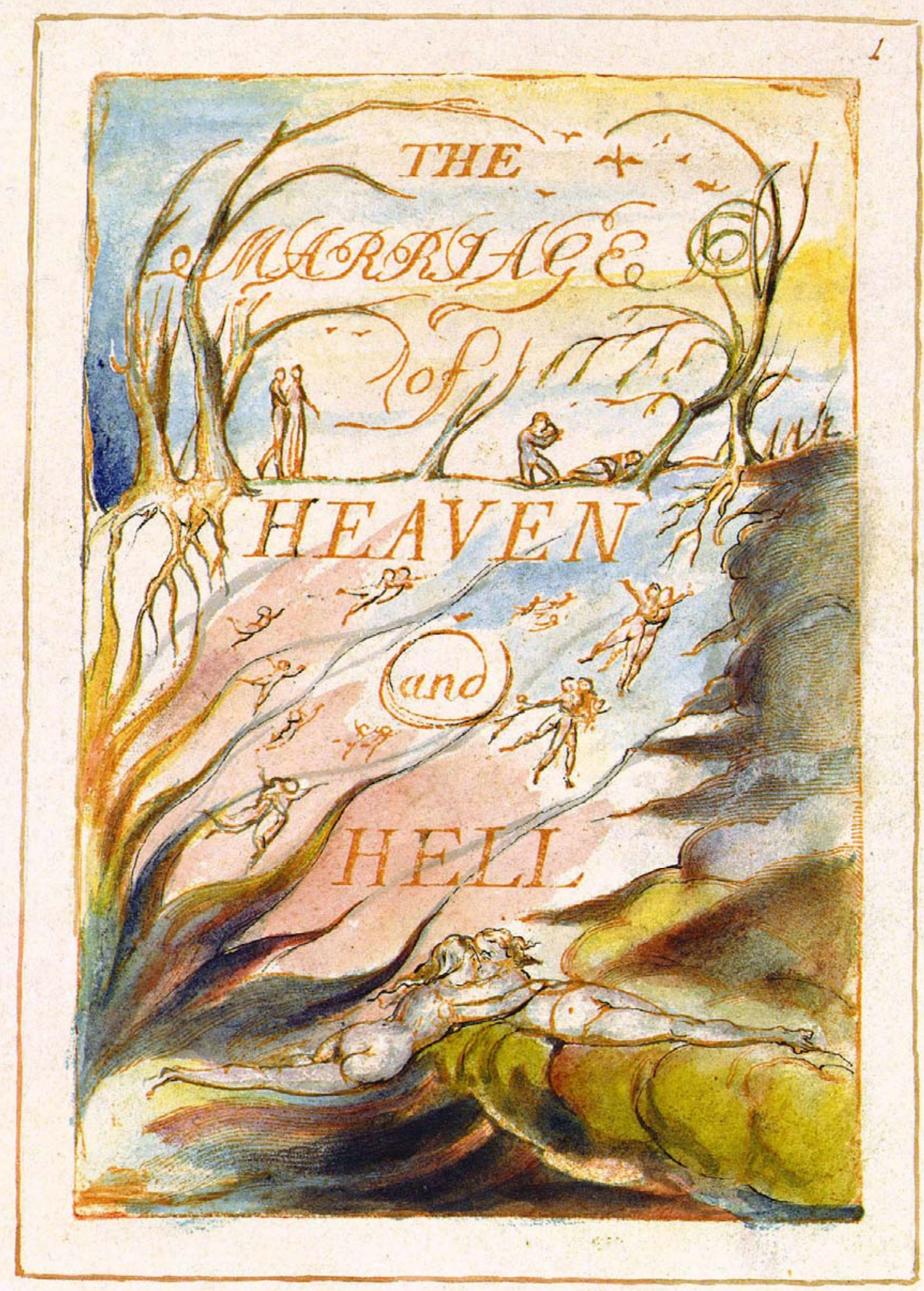

Figure 1

William Blake

The Frontispiece to The Marriage of Heaven and Hell, copy G 1790 


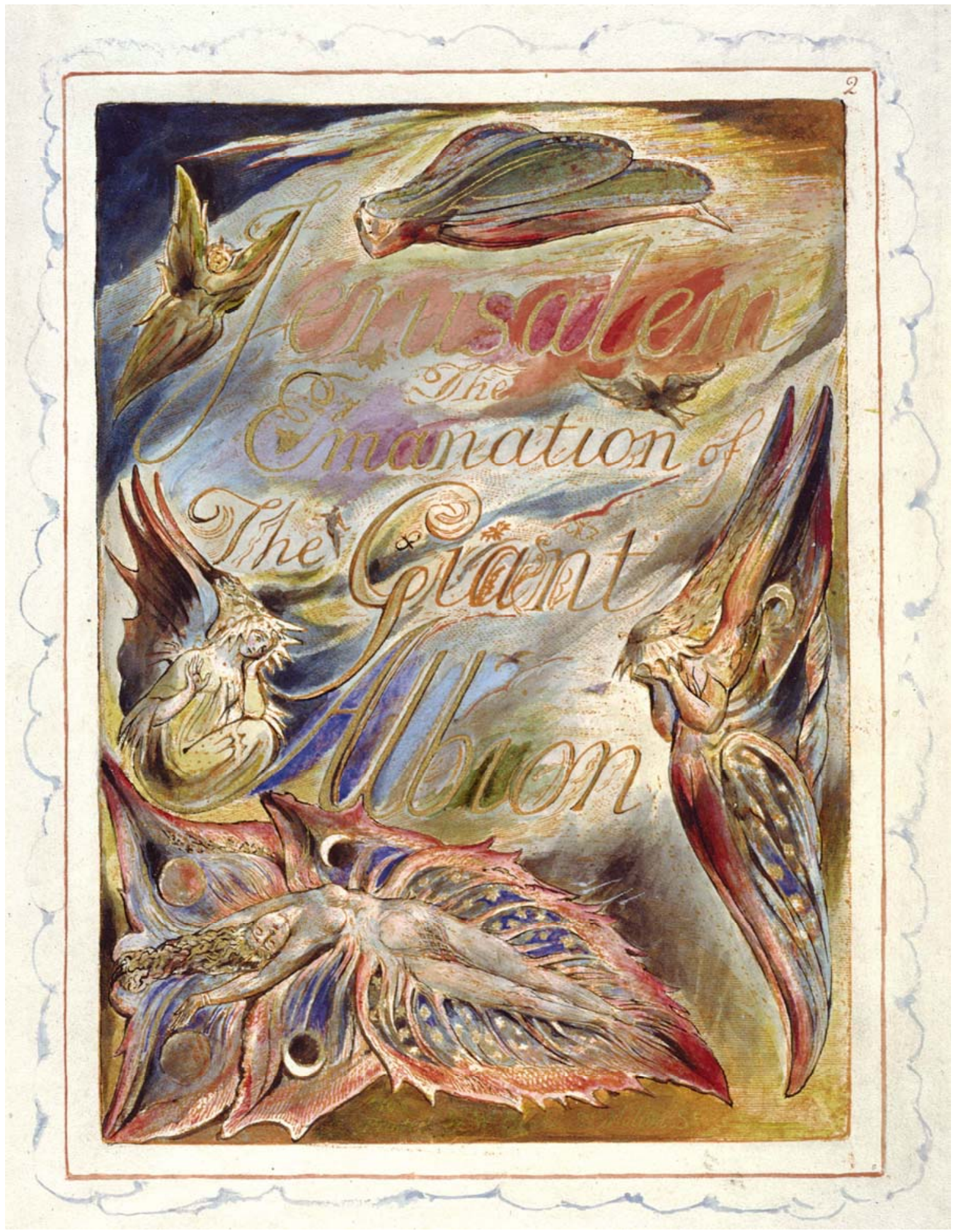

Figure 2

William Blake

Frontispiece from Jerusalem the Emanation of the Giant Albion

1820 


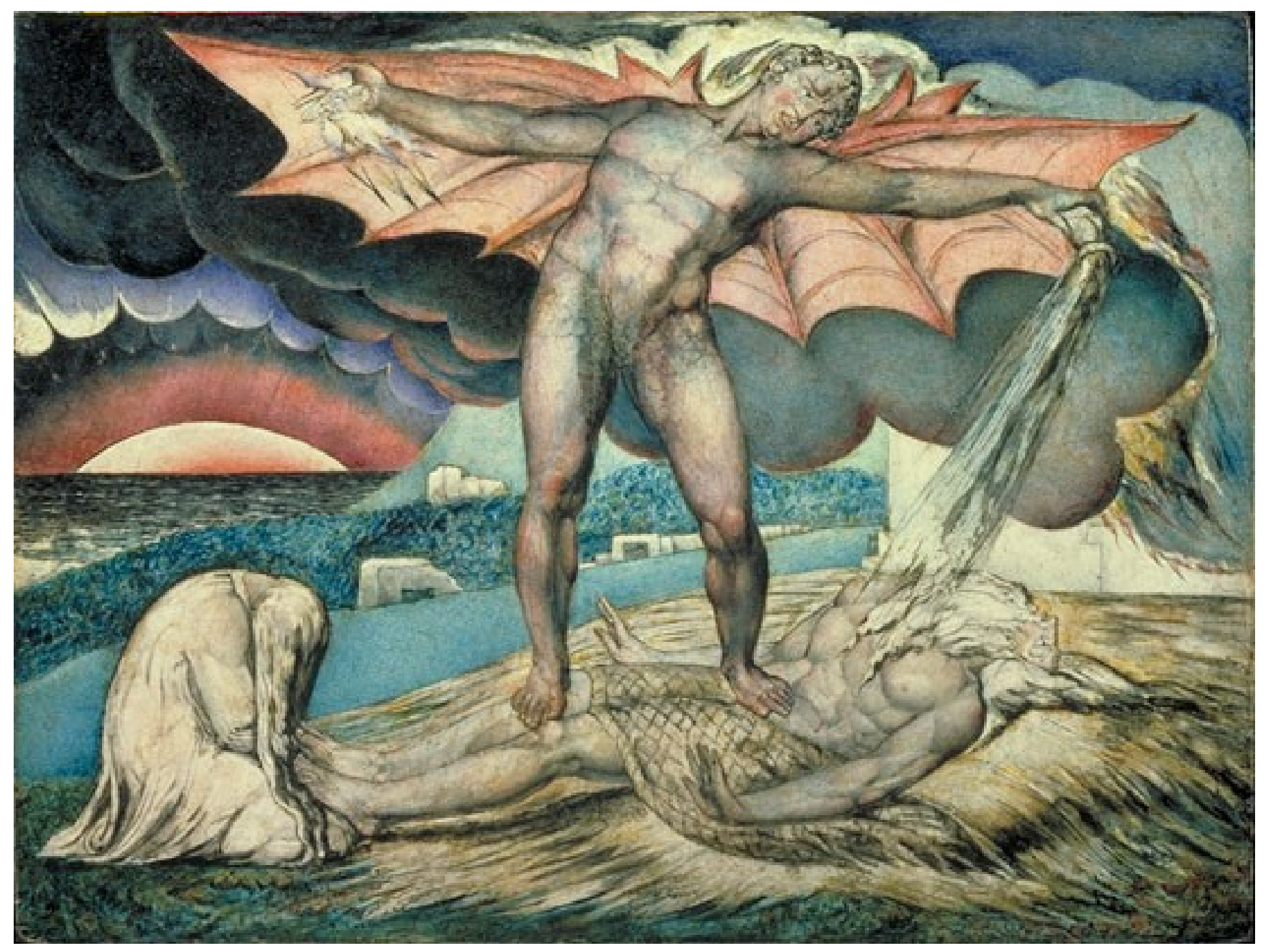

Figure 3

William Blake

Satan Smiting Job with Boils

1793 


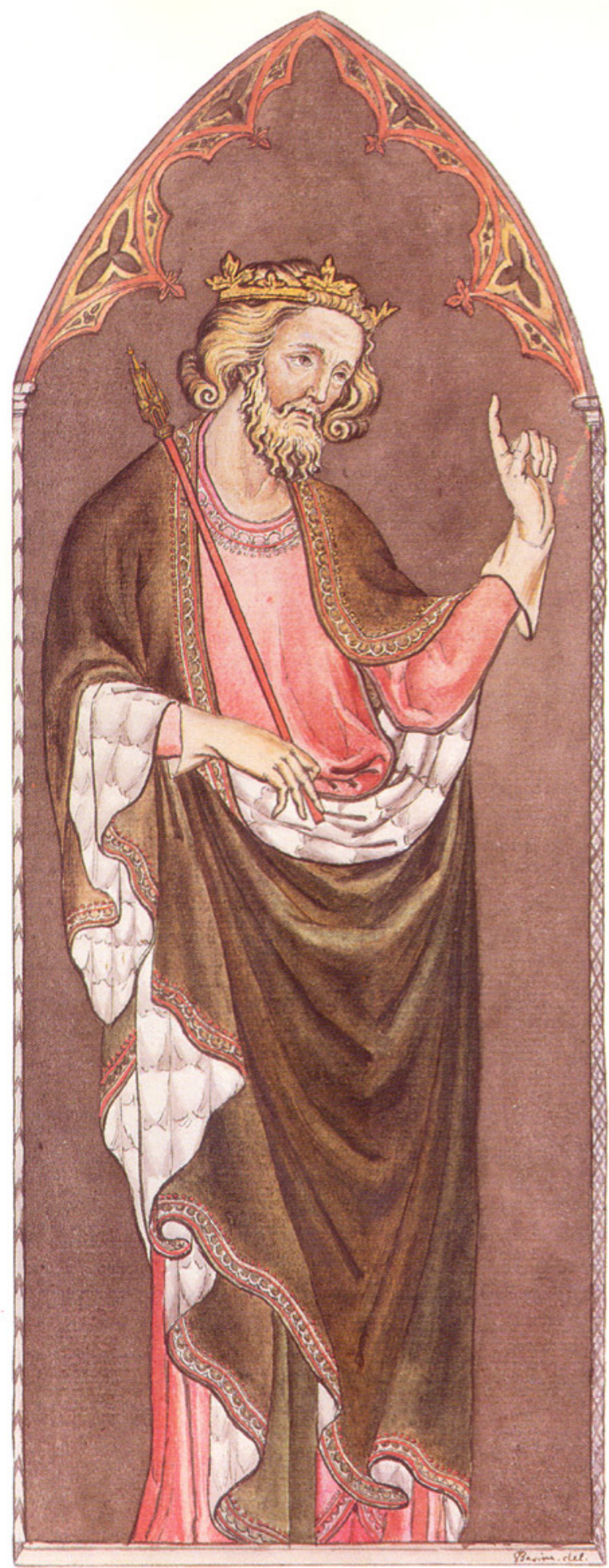

Figure 4

King Serbert, from the wall painting on the Sedelia above his Monument William Blake

pen, watercolor, and gold sheet 1775 


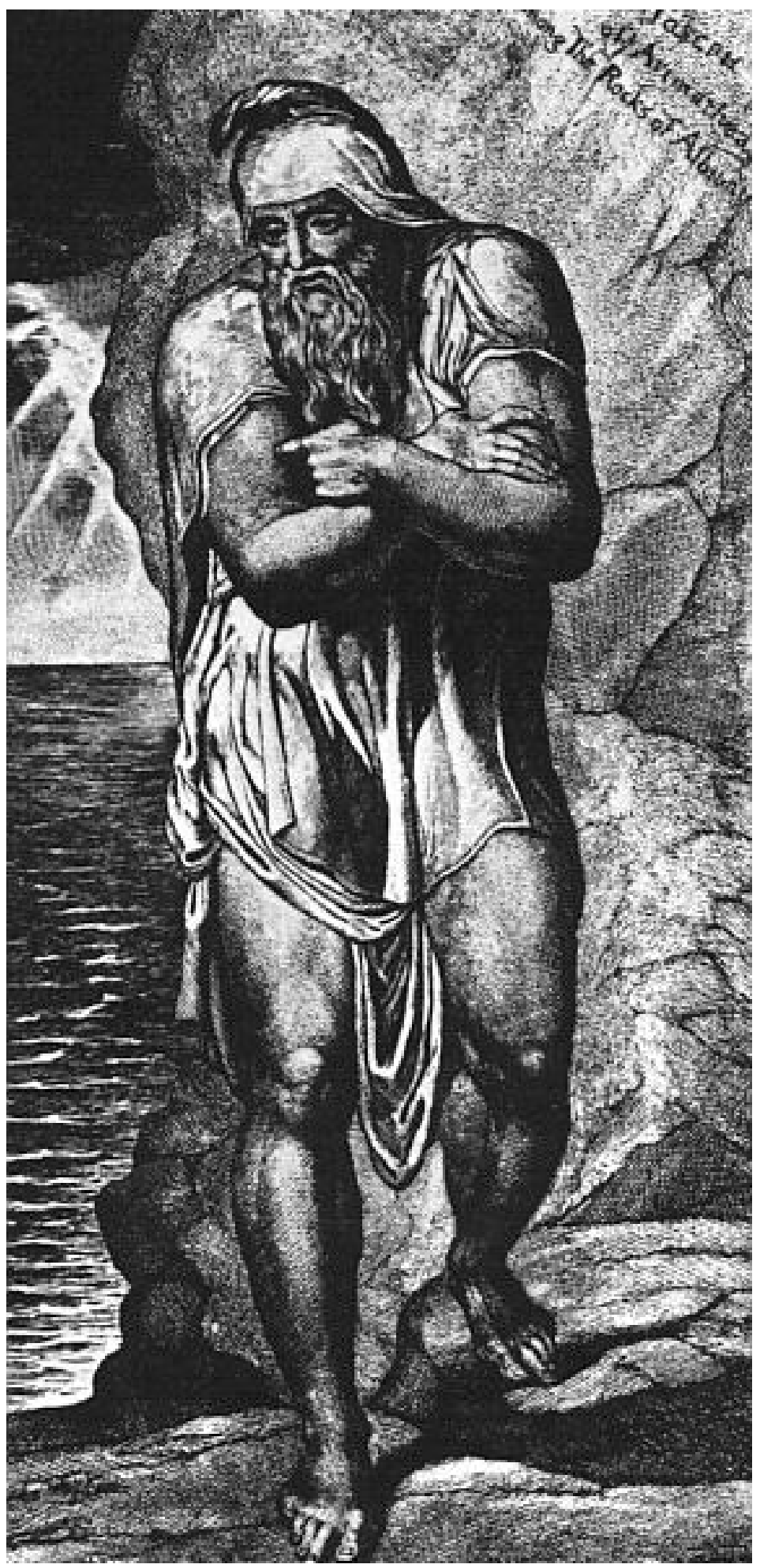

Figure 5

Joseph of Arimathea among the Rock of Albion

William Blake

Engraving

$1773 / 1818$ 


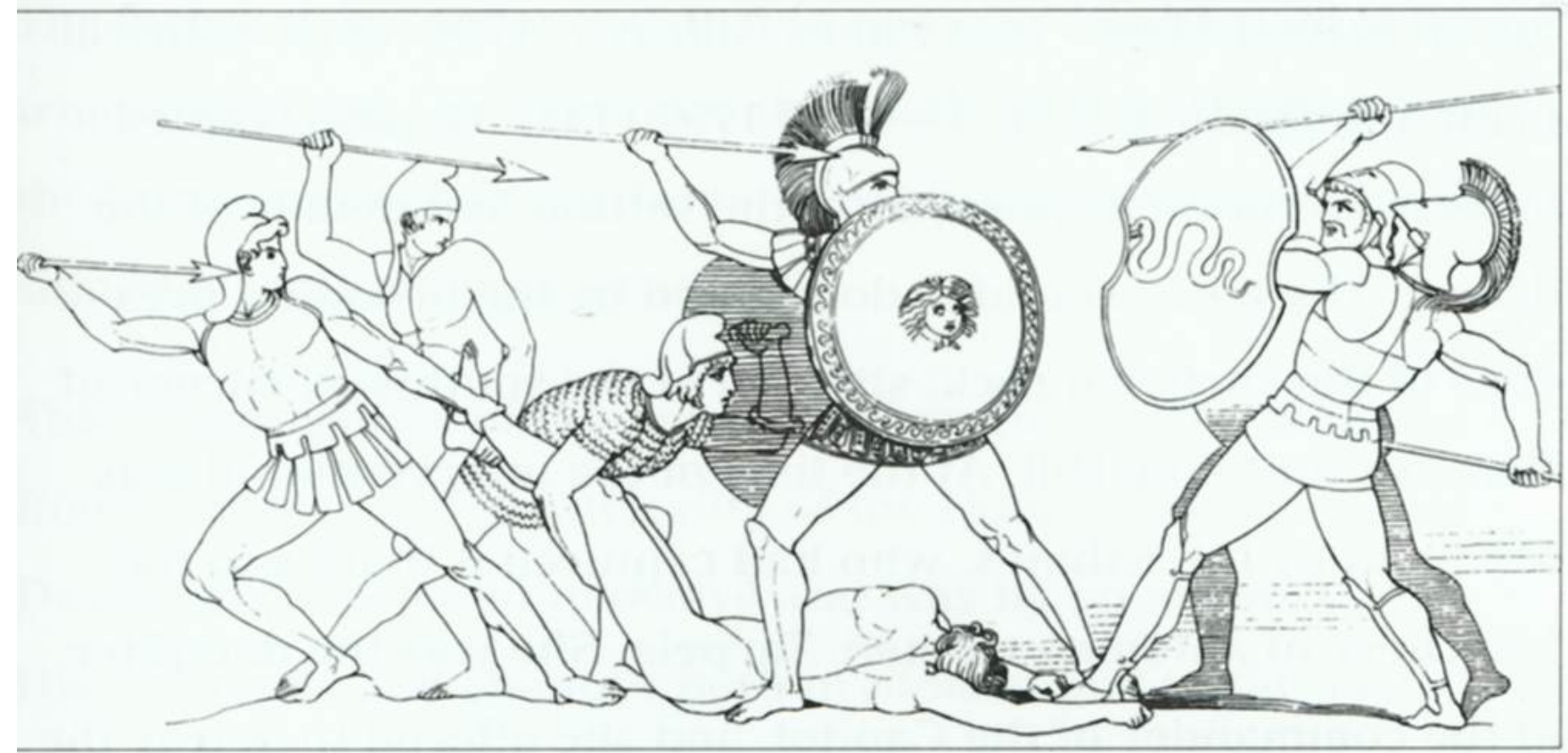

Figure 6

John Flaxman

Fight over the body of Patrocles

1793 


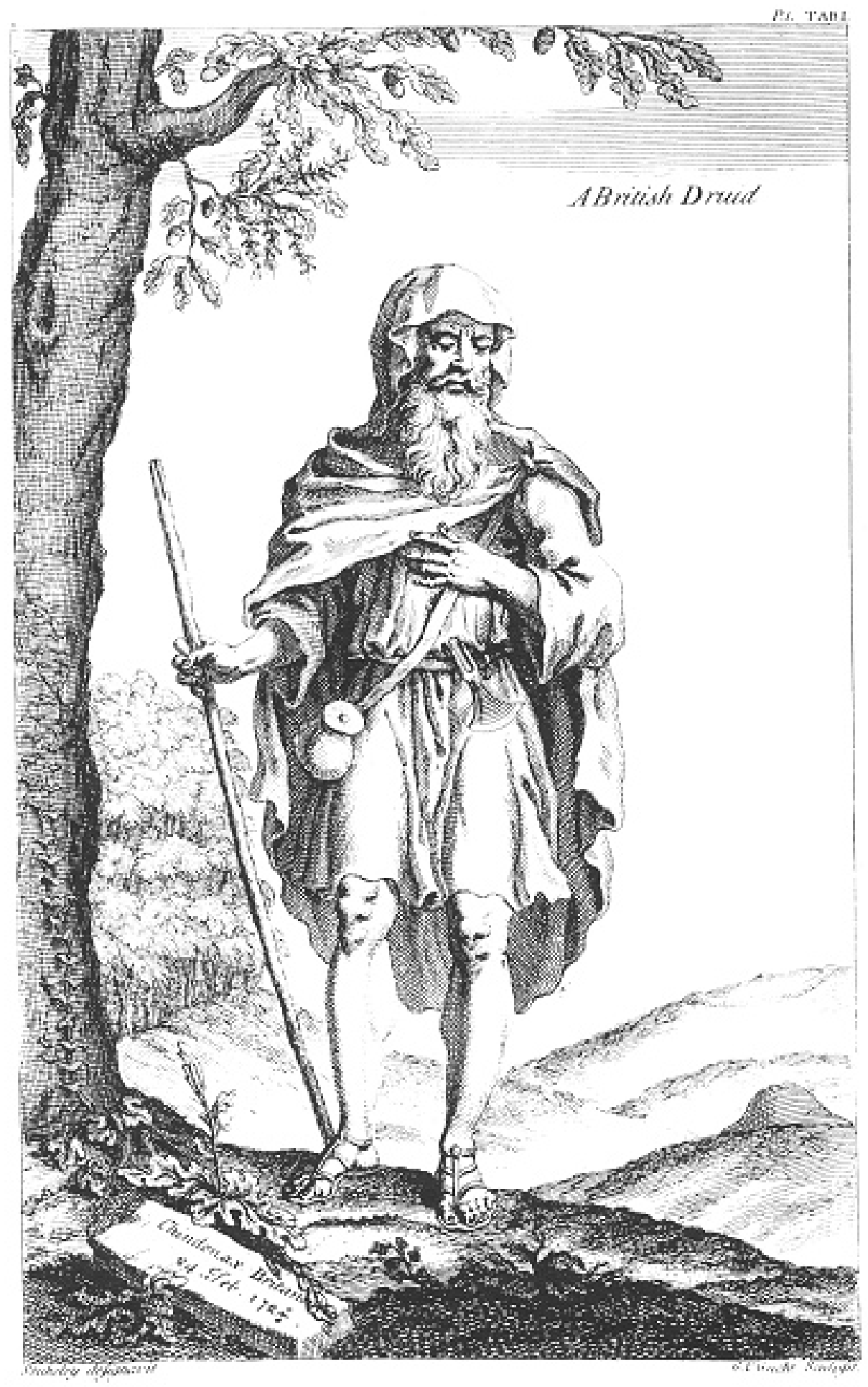

Figure 7

A British Druid

From William Stukeley's Stonehenge: A Temple Restored to the British Druids Plate 1 


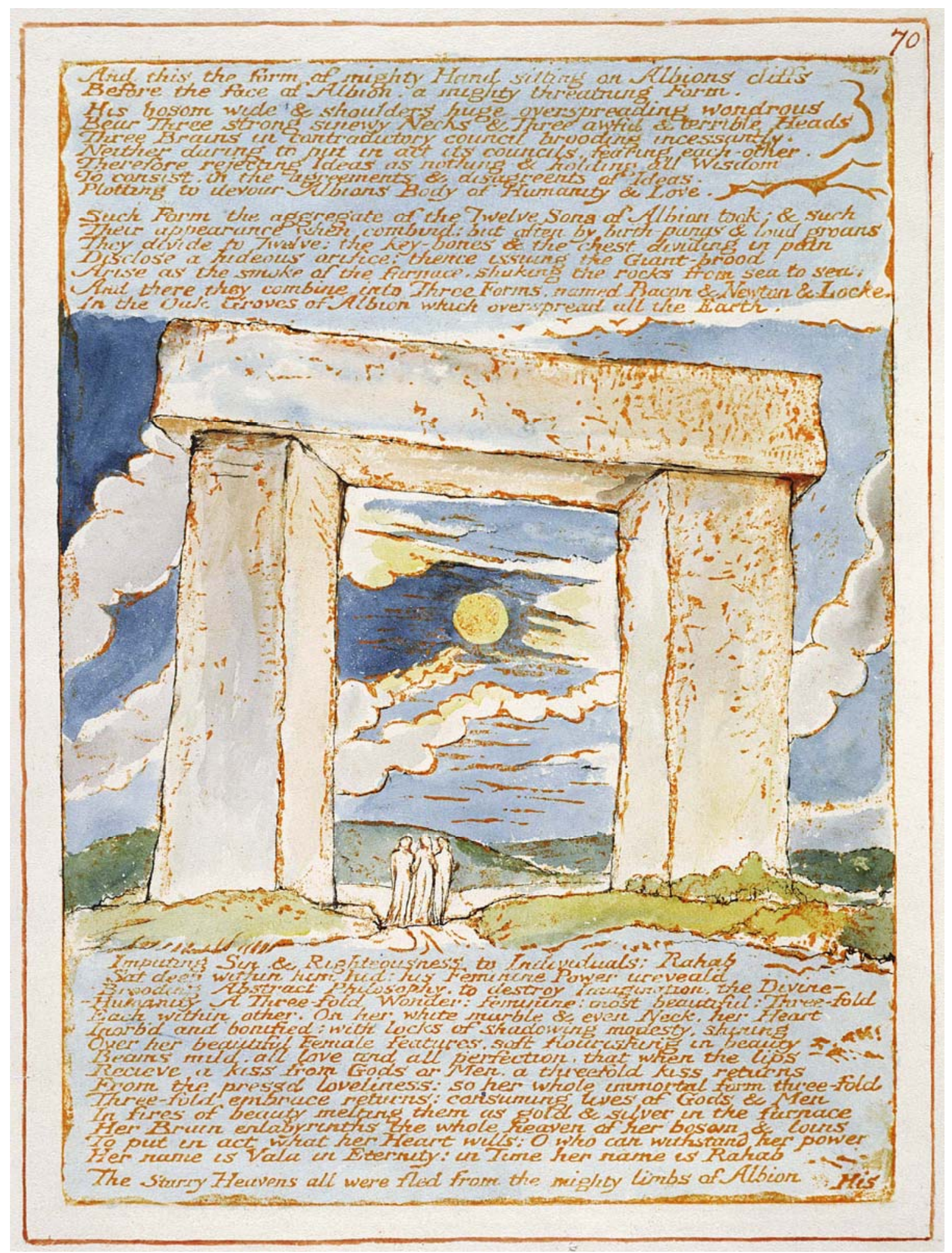

Figure 8

William Blake

Plate 70 from Jerusalem, the Emanation of the Giant Albion 


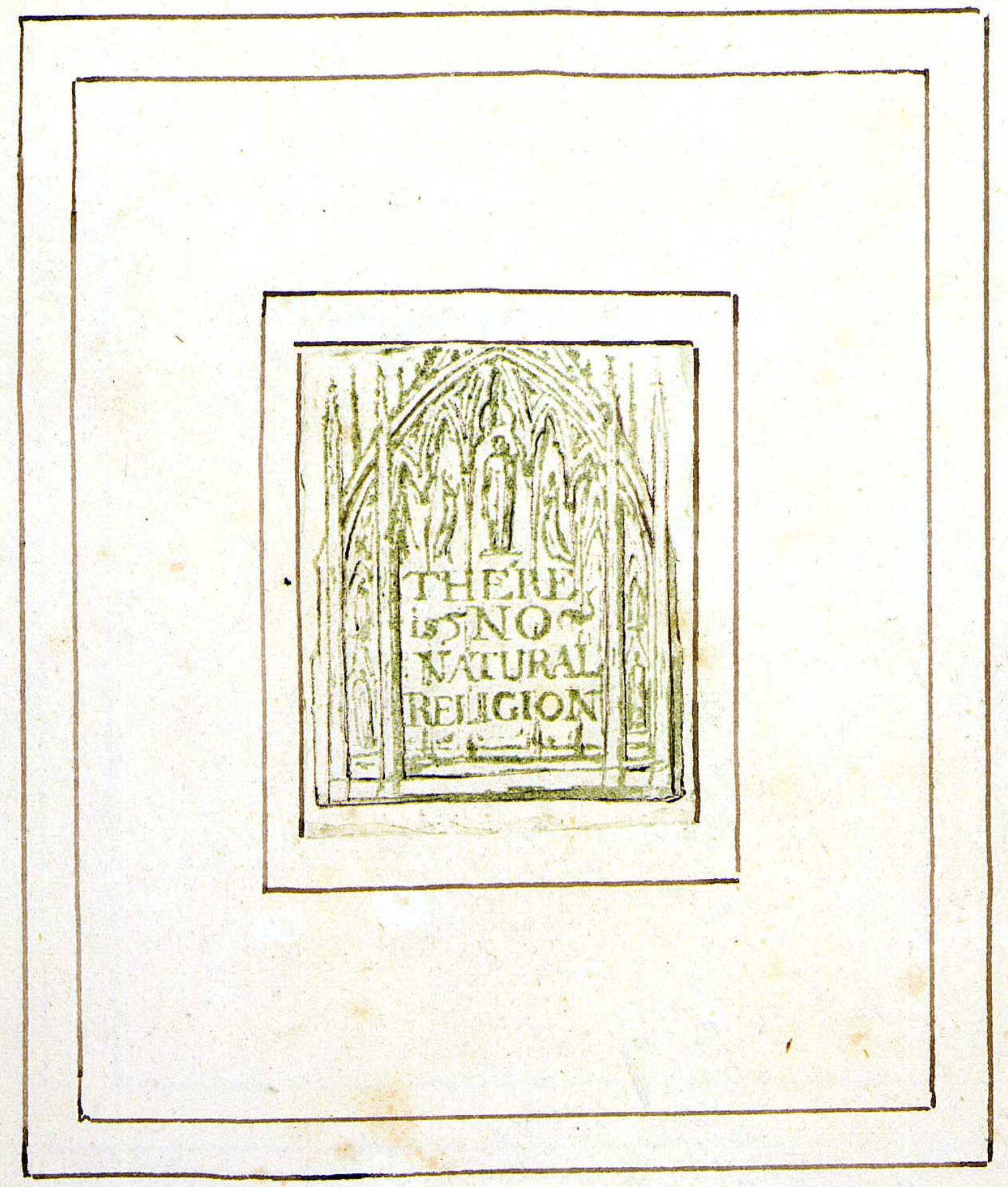

Figure 9

William Blake

Frontispiece from There is No Natural Religion

1798 


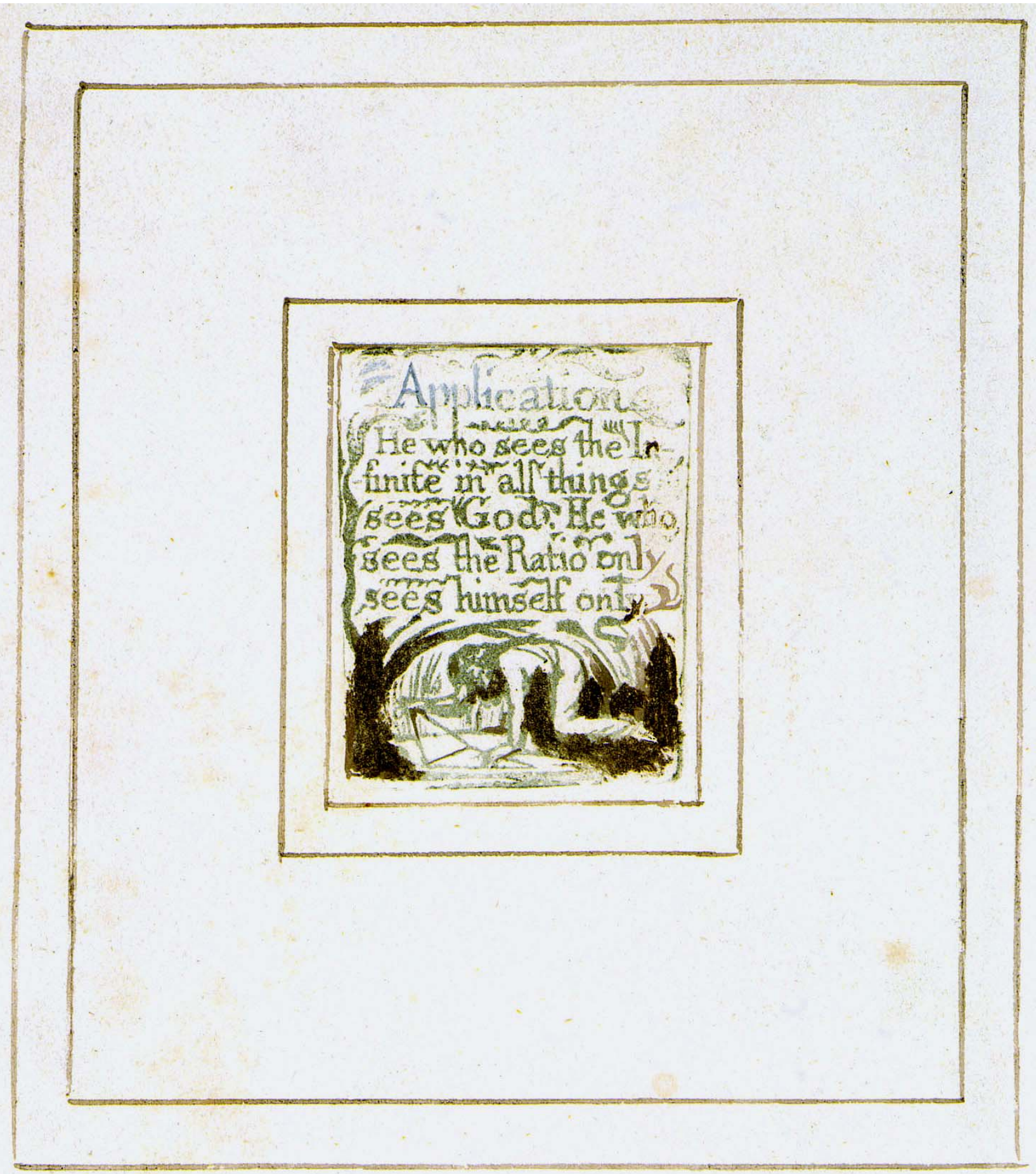

Figure 10

William Blake

There is No Natural Religion, copy L, object 10 c. 1795 


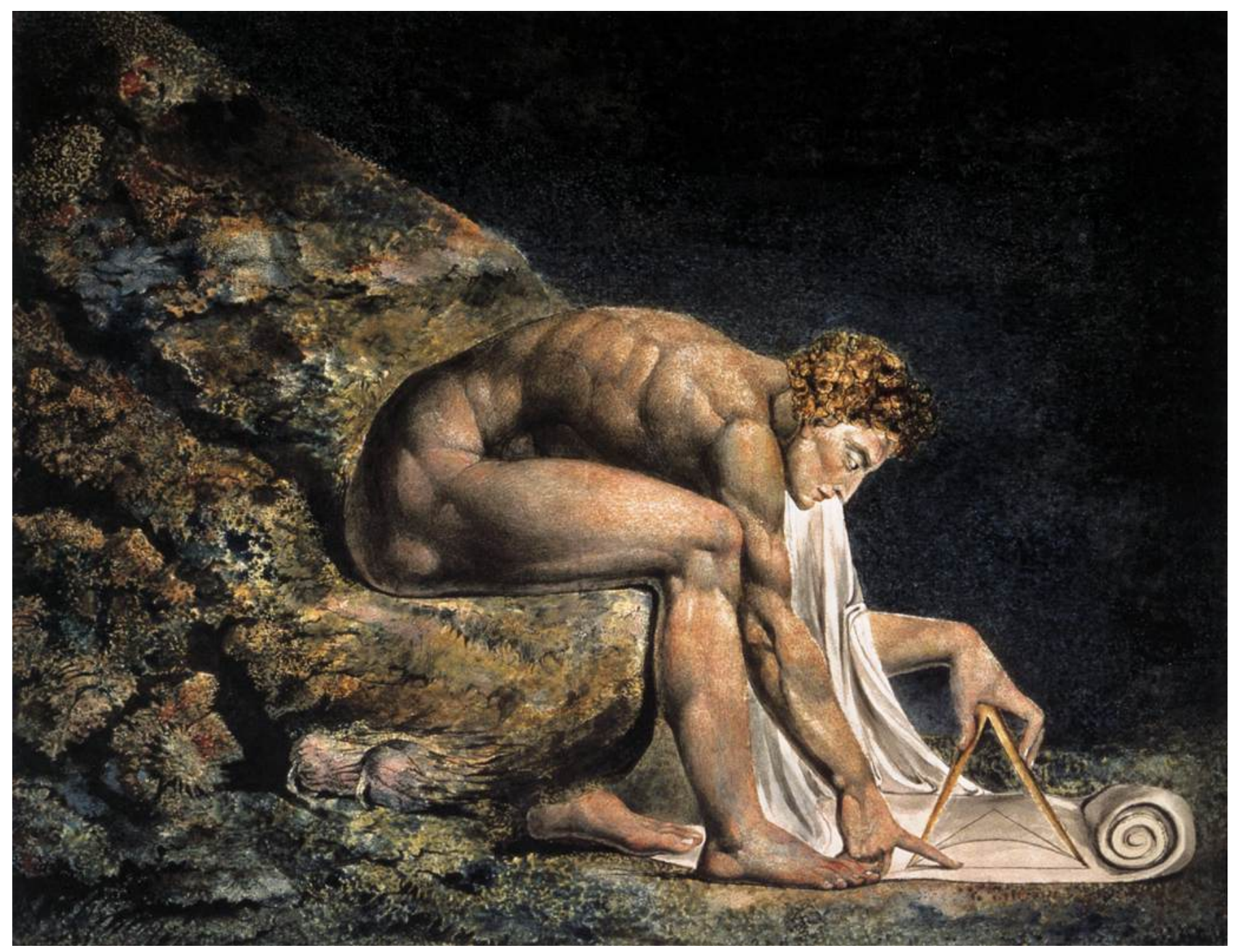

Figure 11

William Blake

"Newton"

c. 1795

Hand-colored print 


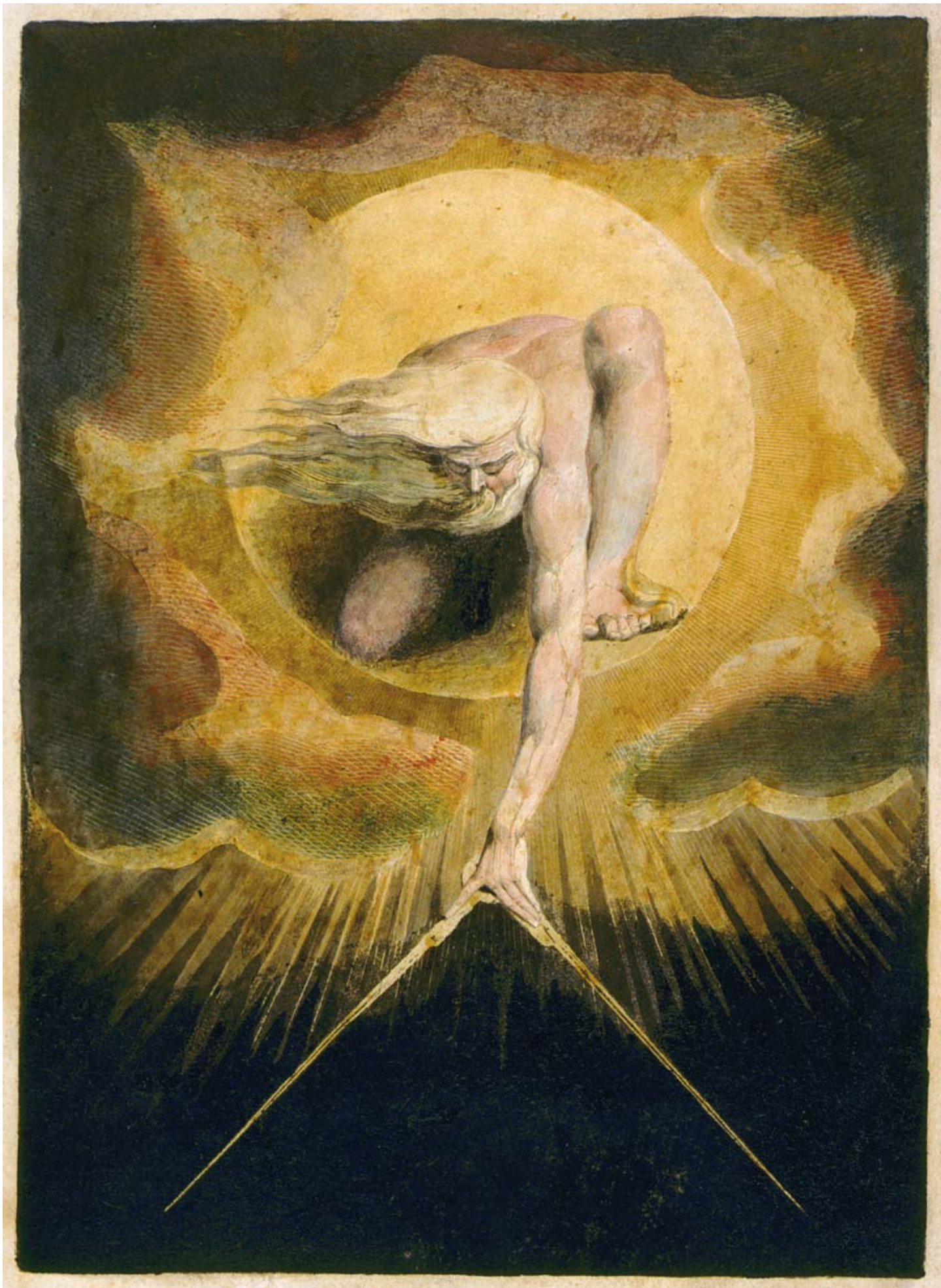

Figure 12

William Blake

'Ancient of Days' from Europe a Prophecy, copy E, object 1 1794 


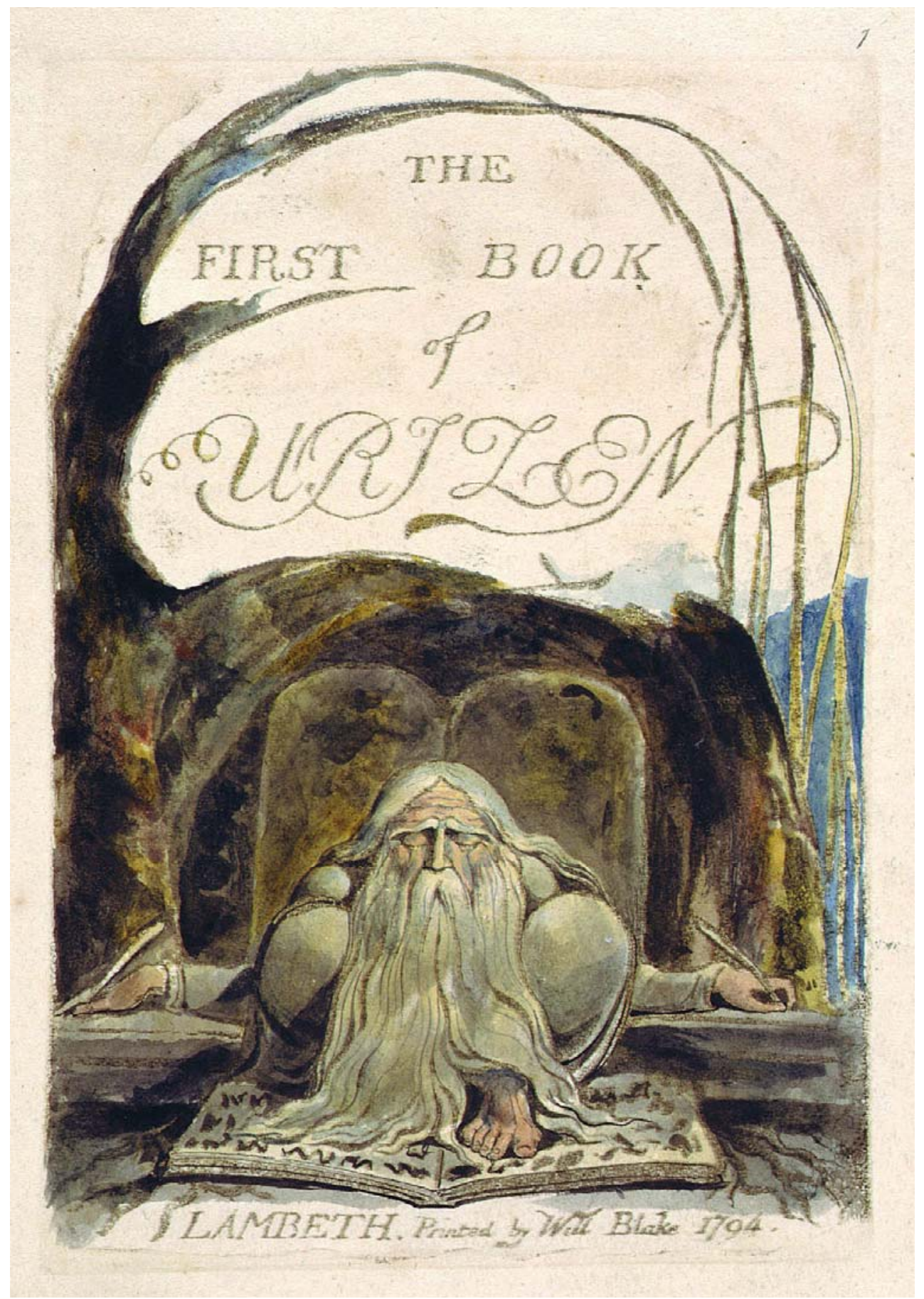

Figure 13

William Blake

Plate 1 of The First Book of Urizen; Urizen

Hand-colored print 


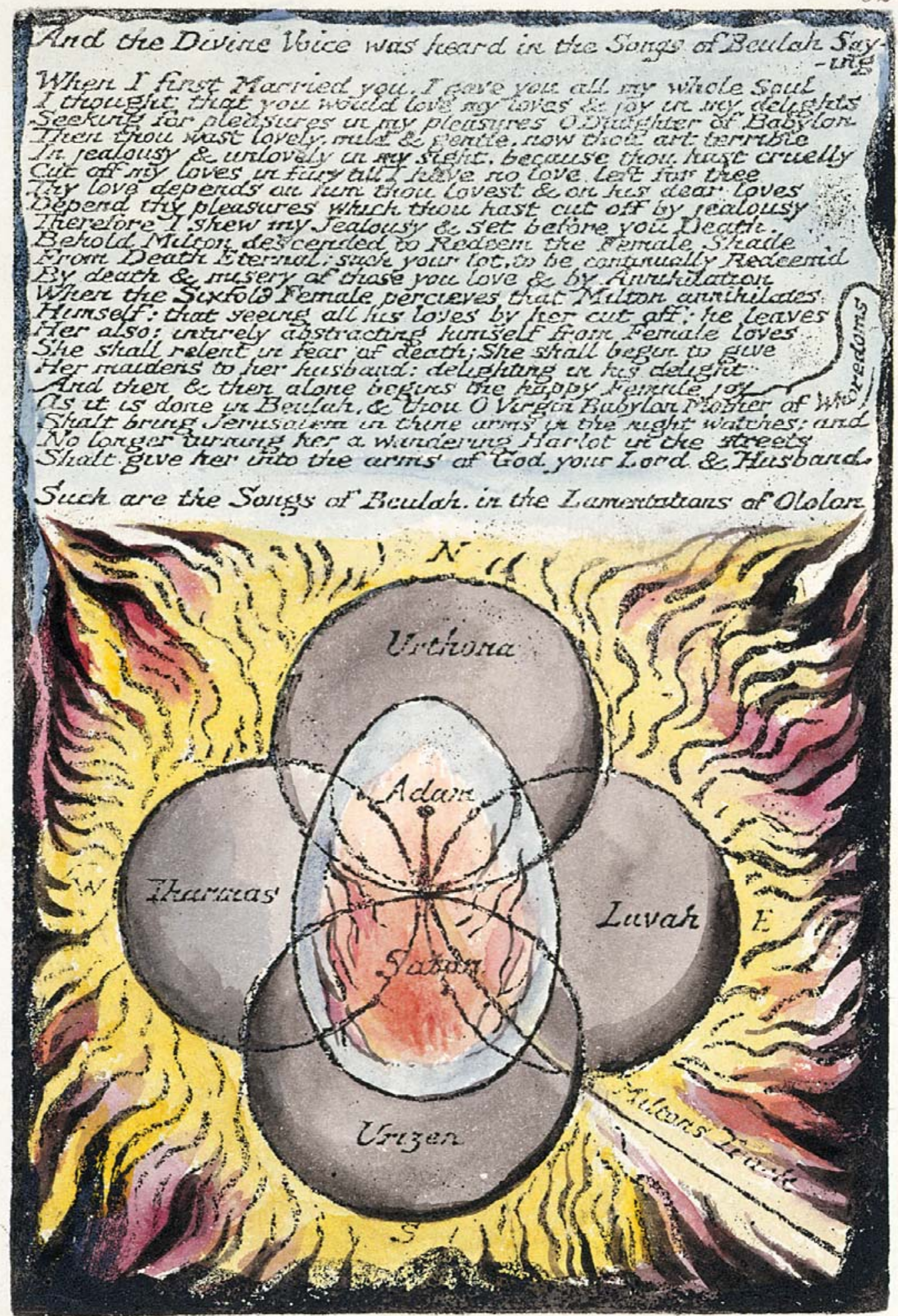

Figure 14

William Blake

Plate 32 from Milton, a Poem

1804-1811 


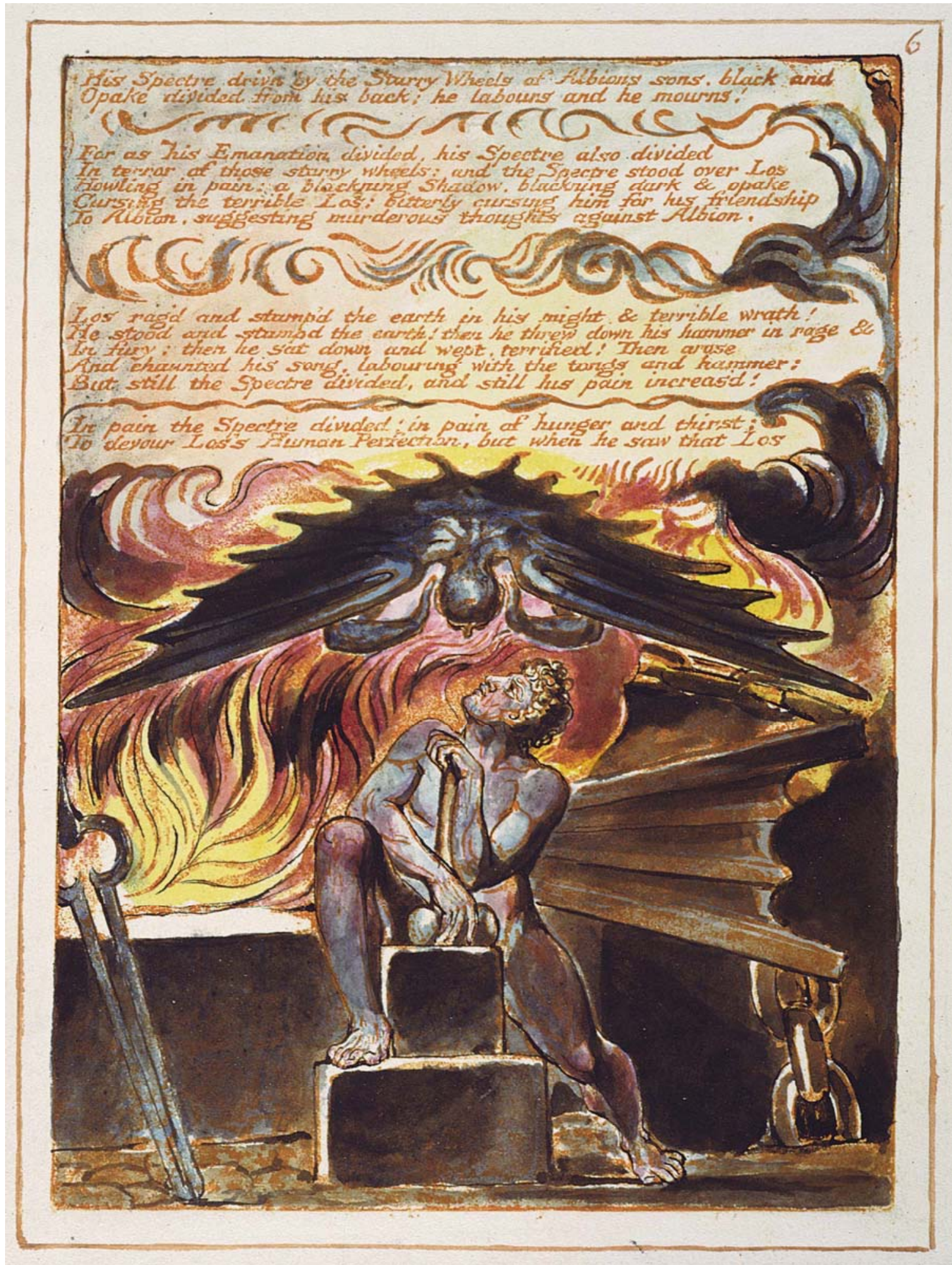

Figure 15

William Blake

Plate 6 from Jerusalem, the Emanation of the Giant Albion, Los 1820 


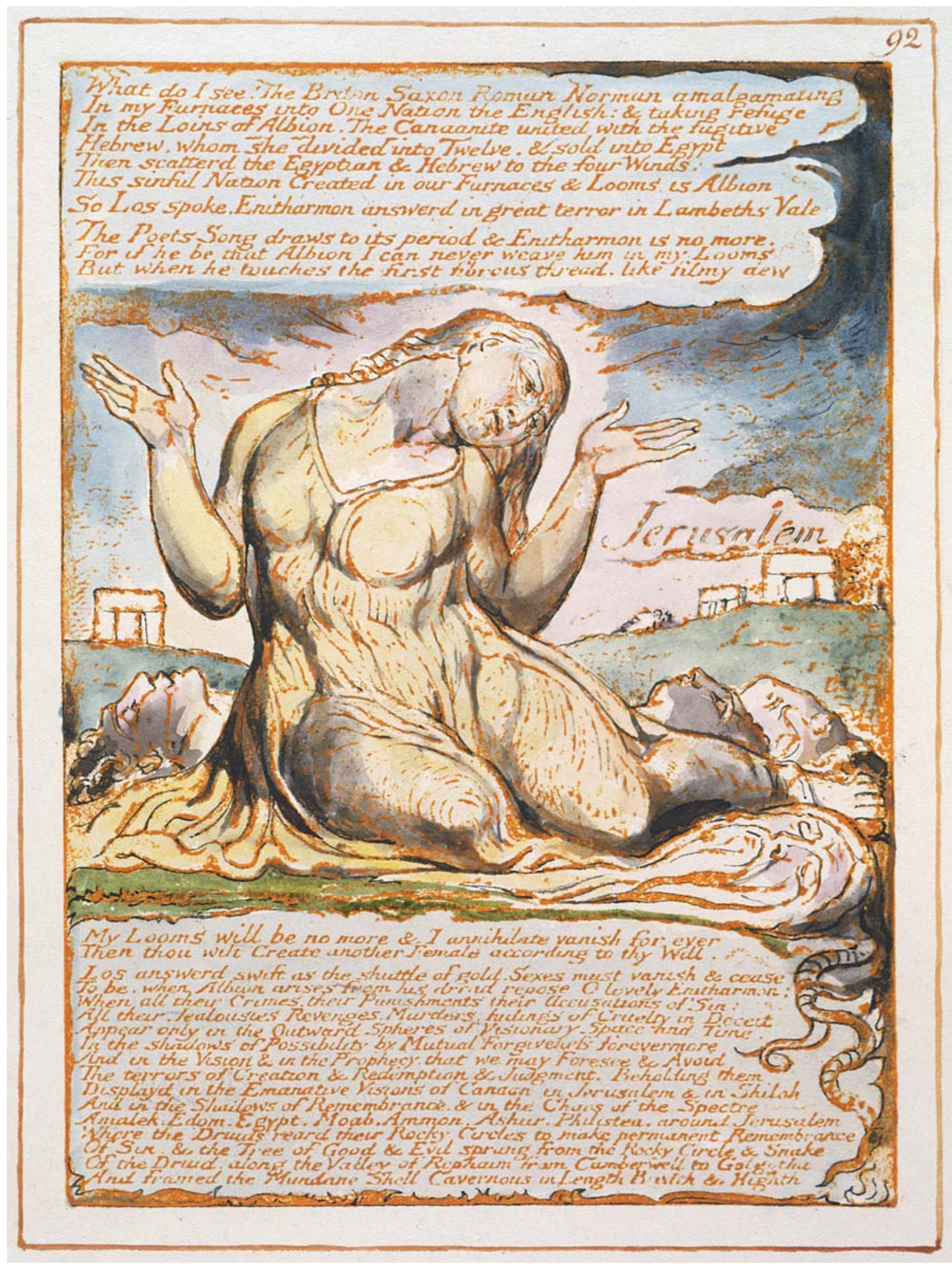

Figure 16

William Blake

Plate 92 from Jerusalem, the Emanation of the Giant Albion, Luvah 1820 


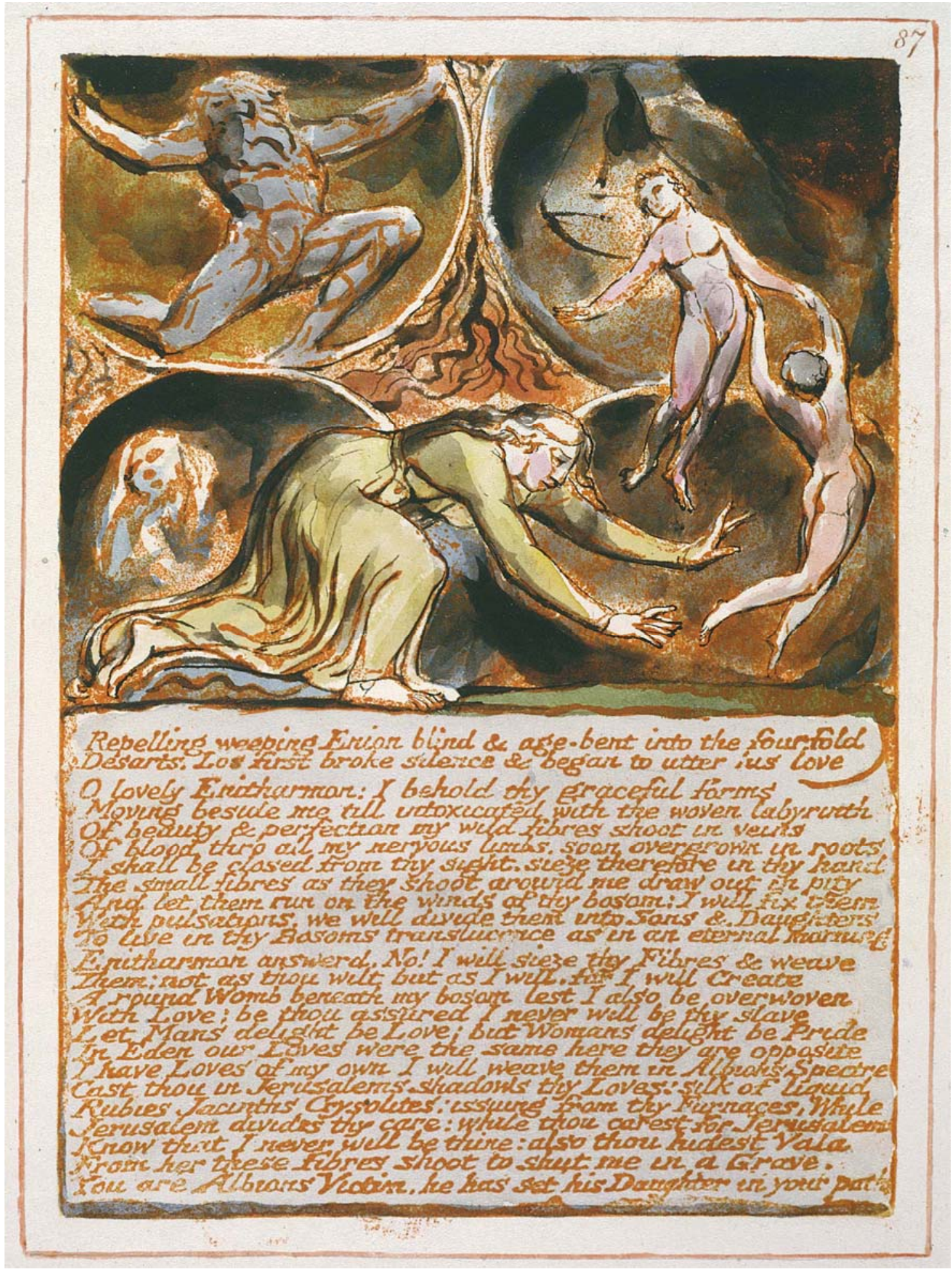

Figure 17

William Blake

Plate 87 from Jerusalem, the Emanation of the Giant Albion, Enitharmon 1820 


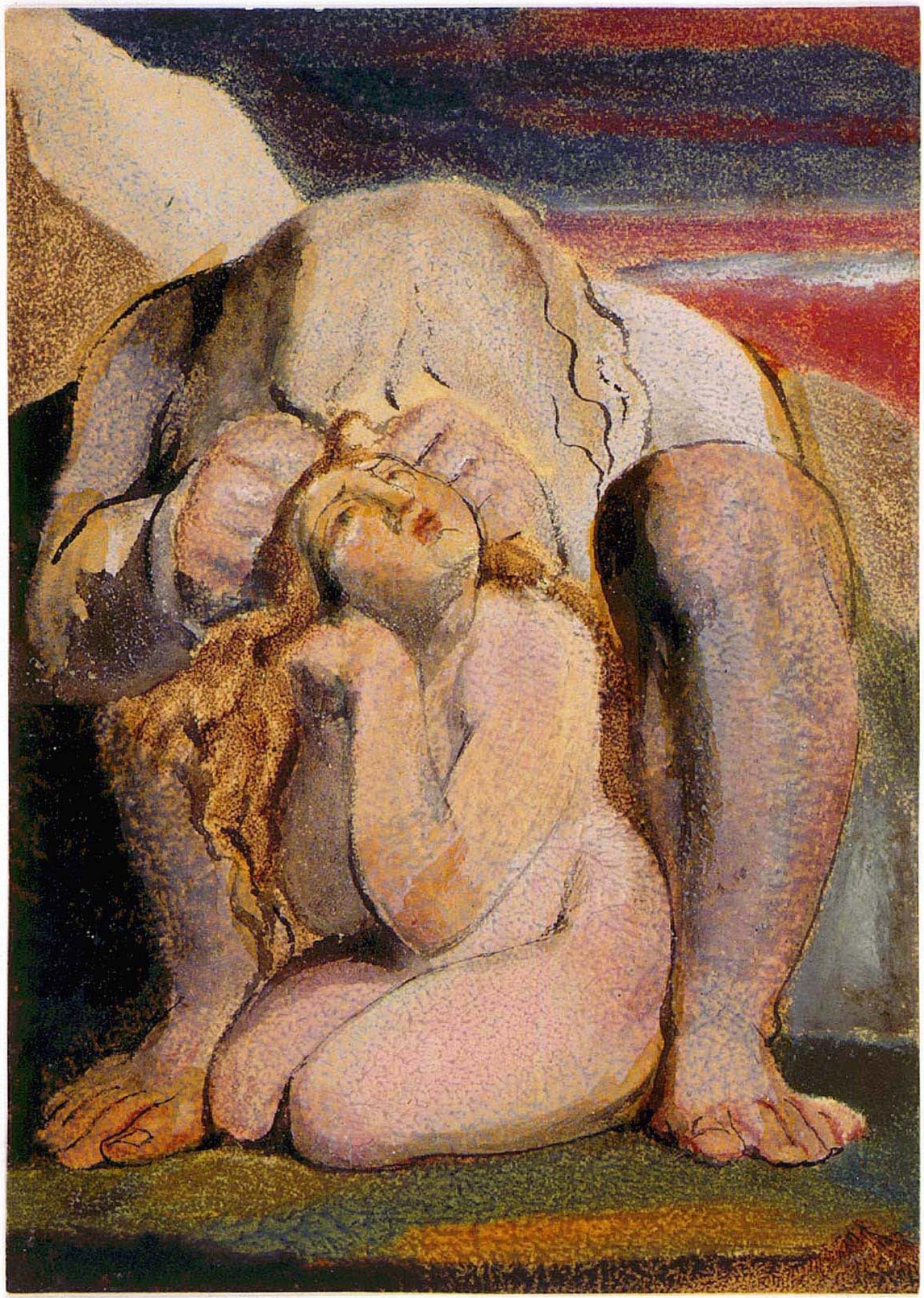

Figure 18

William Blake

"Ahania and Urizen" from the Book of Ahania

1795 


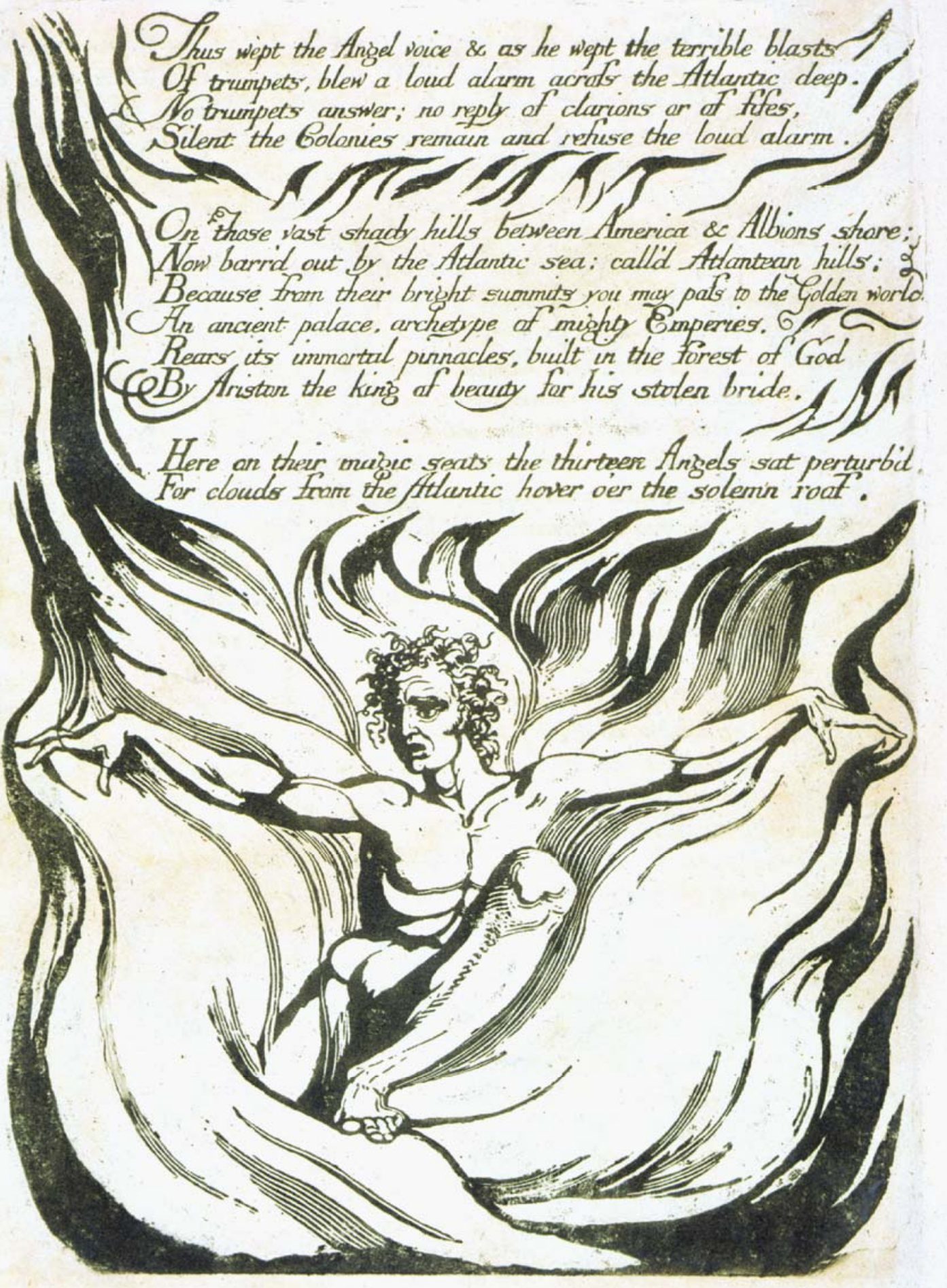

Figure 19

William Blake

Plate 12 from America, a Prophecy, Orc 


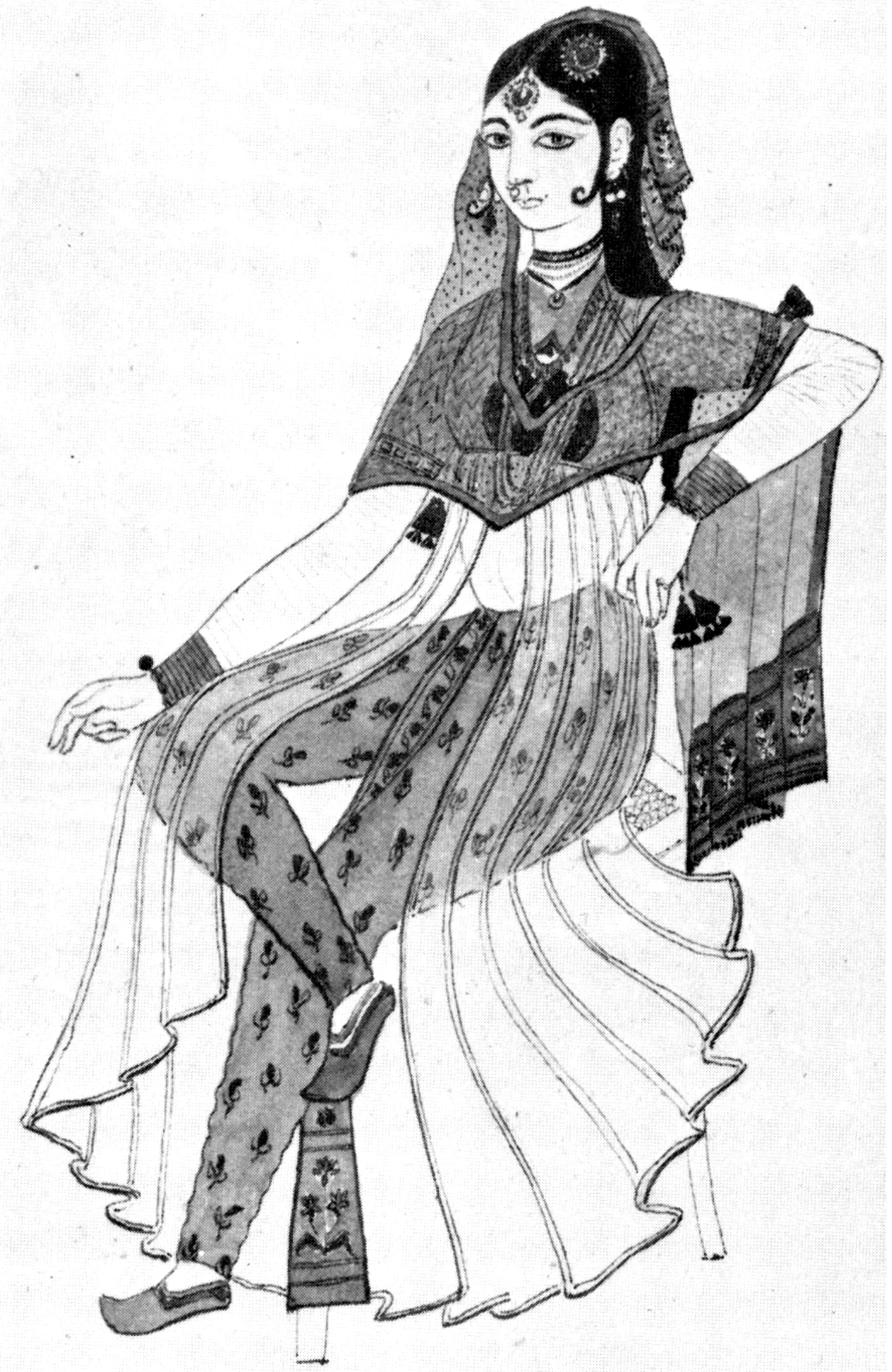

Figure 20

John Flaxman

Woman in Indian Costume 


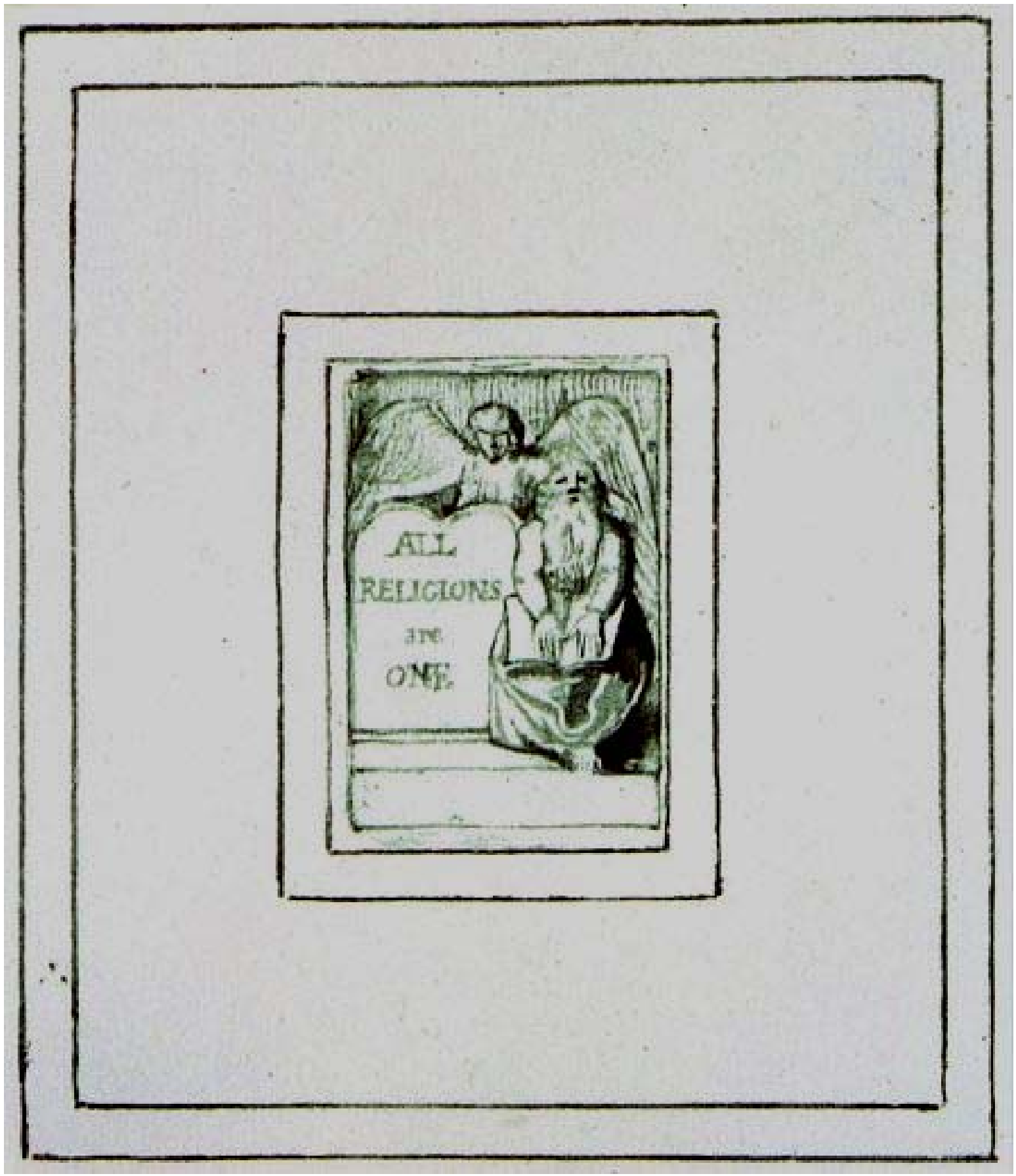

Figure 21

William Blake

Frontispeice of All Religions are One

c. 1788 


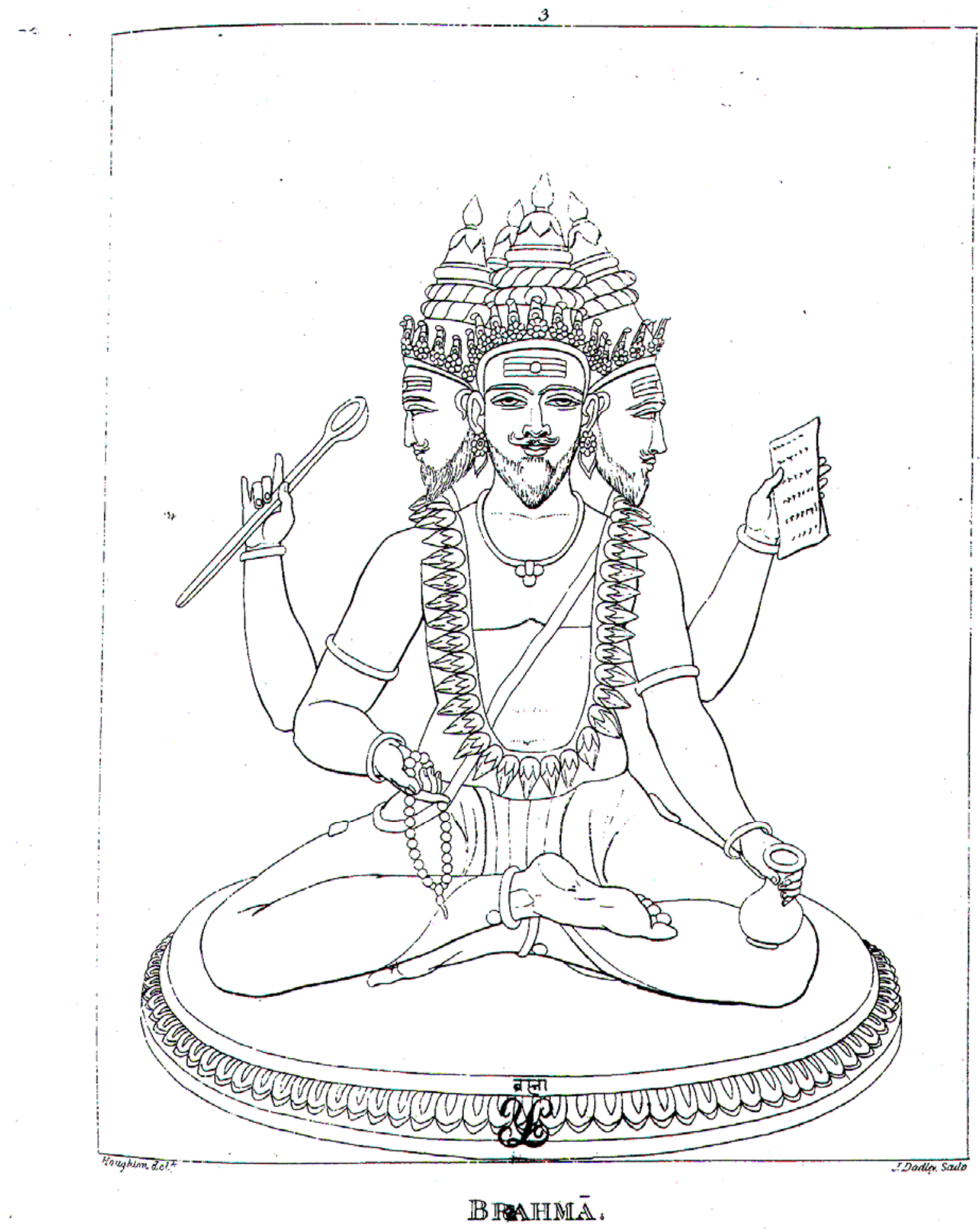

Figure 22

Moses Haughton

Brahma from Moor's The Hindu Pantheon, Plate 3 


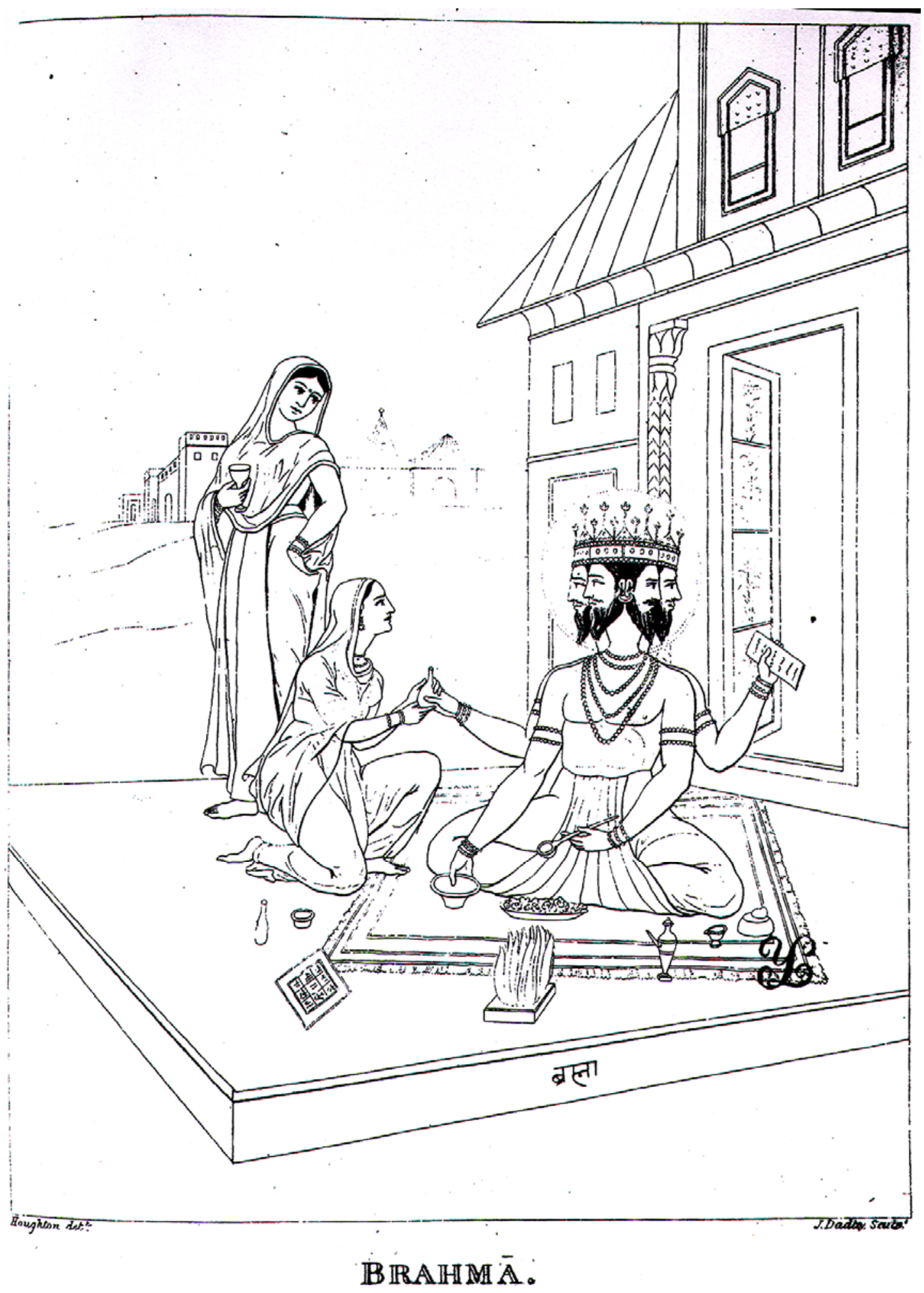

Figure 23

Moses Haughton

Brahma from Moor's The Hindu Pantheon, Plate 4 


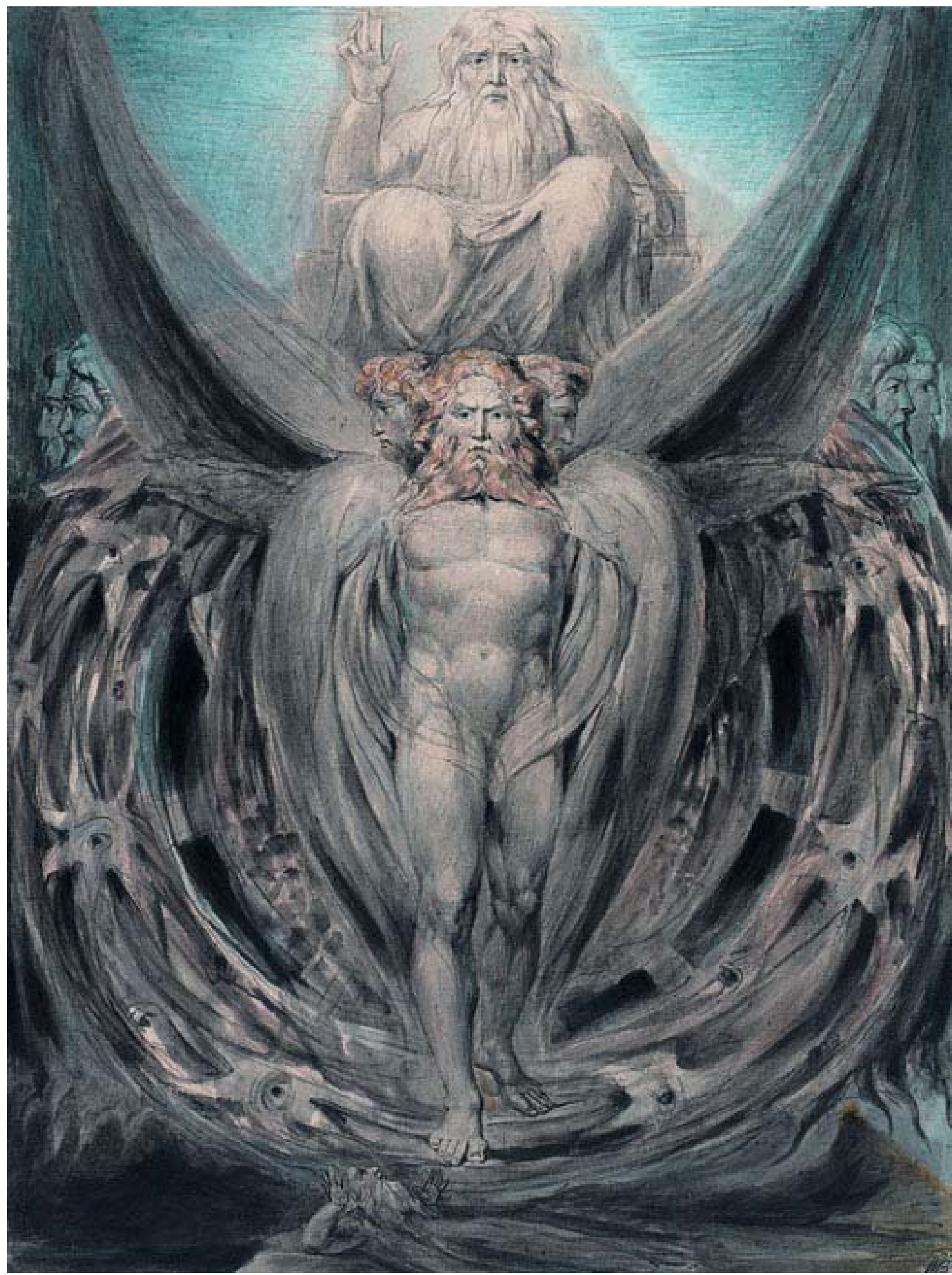

Figure 24

William Blake

Ezekiel's Vision

1803-1805 


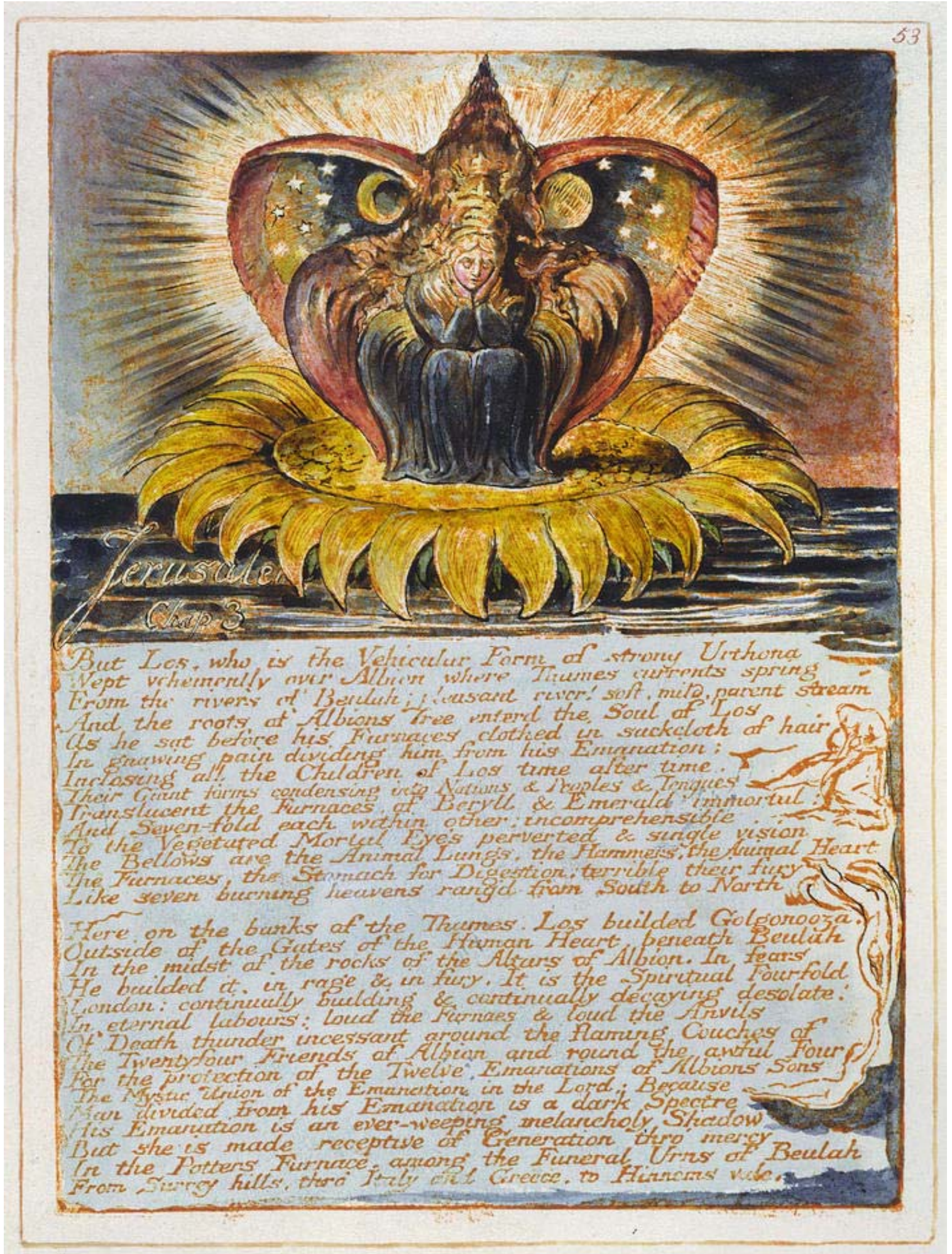

Figure 25

William Blake

Plate 53 of Jerusalem, the Emanation of the Giant Albion, Jerusalem 1820 


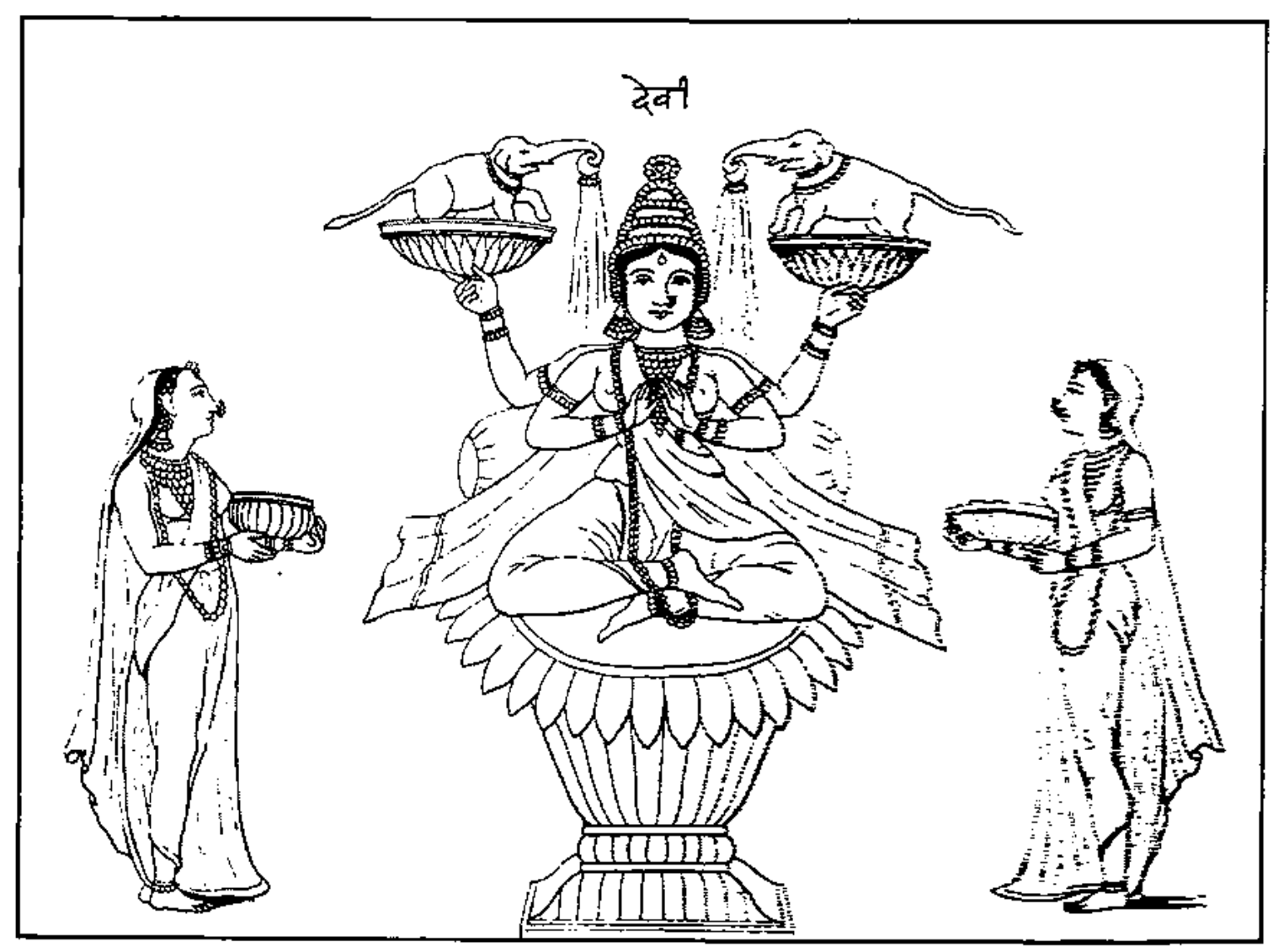

Figure 26

Moses Haughton

Padma-Devi from Moor's The Hindu Pantheon 


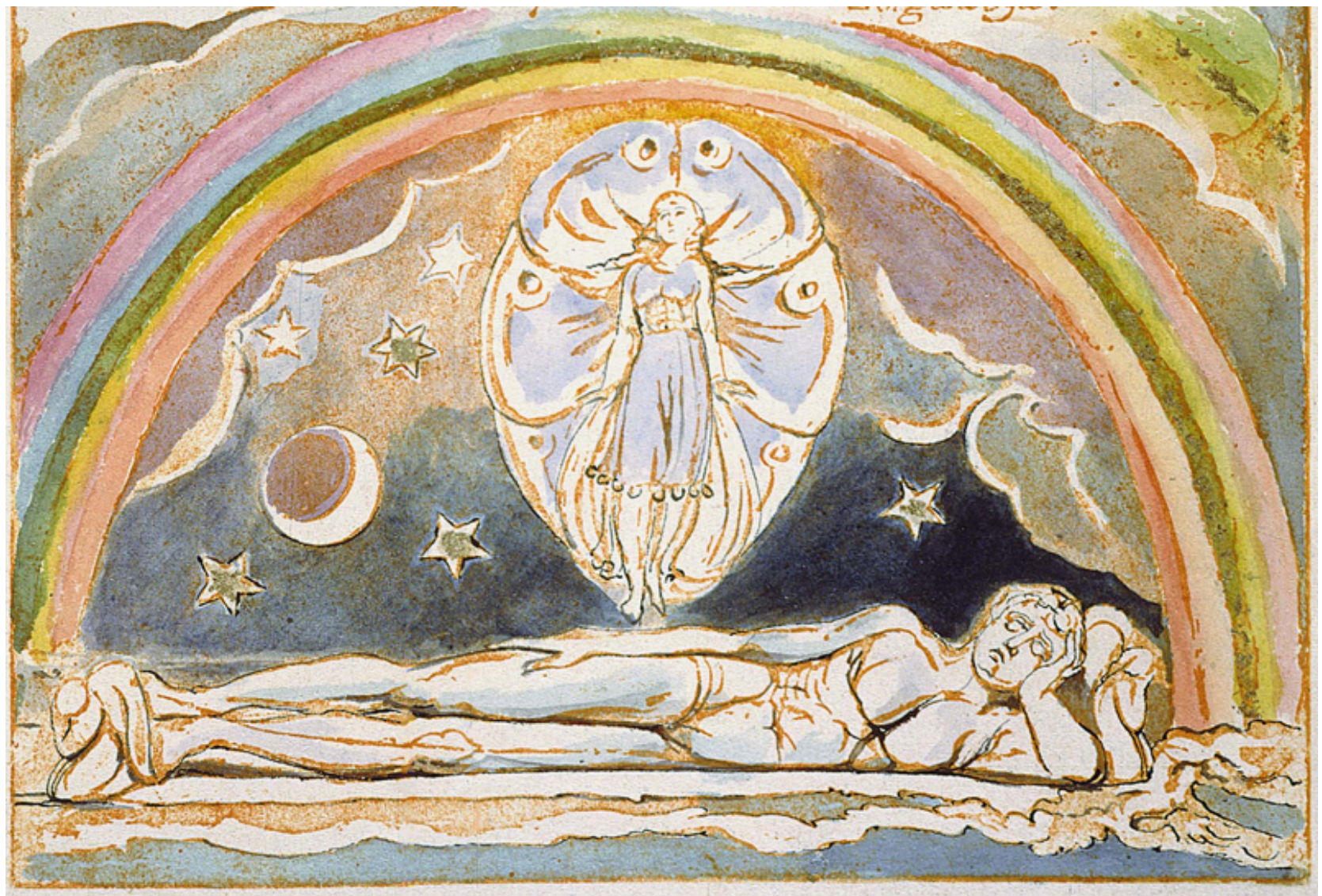

Figure 27

William Blake

Detail of Plate 14 of Jerusalem, the Emanation of the Giant Albion, Albion and Vala 1820 


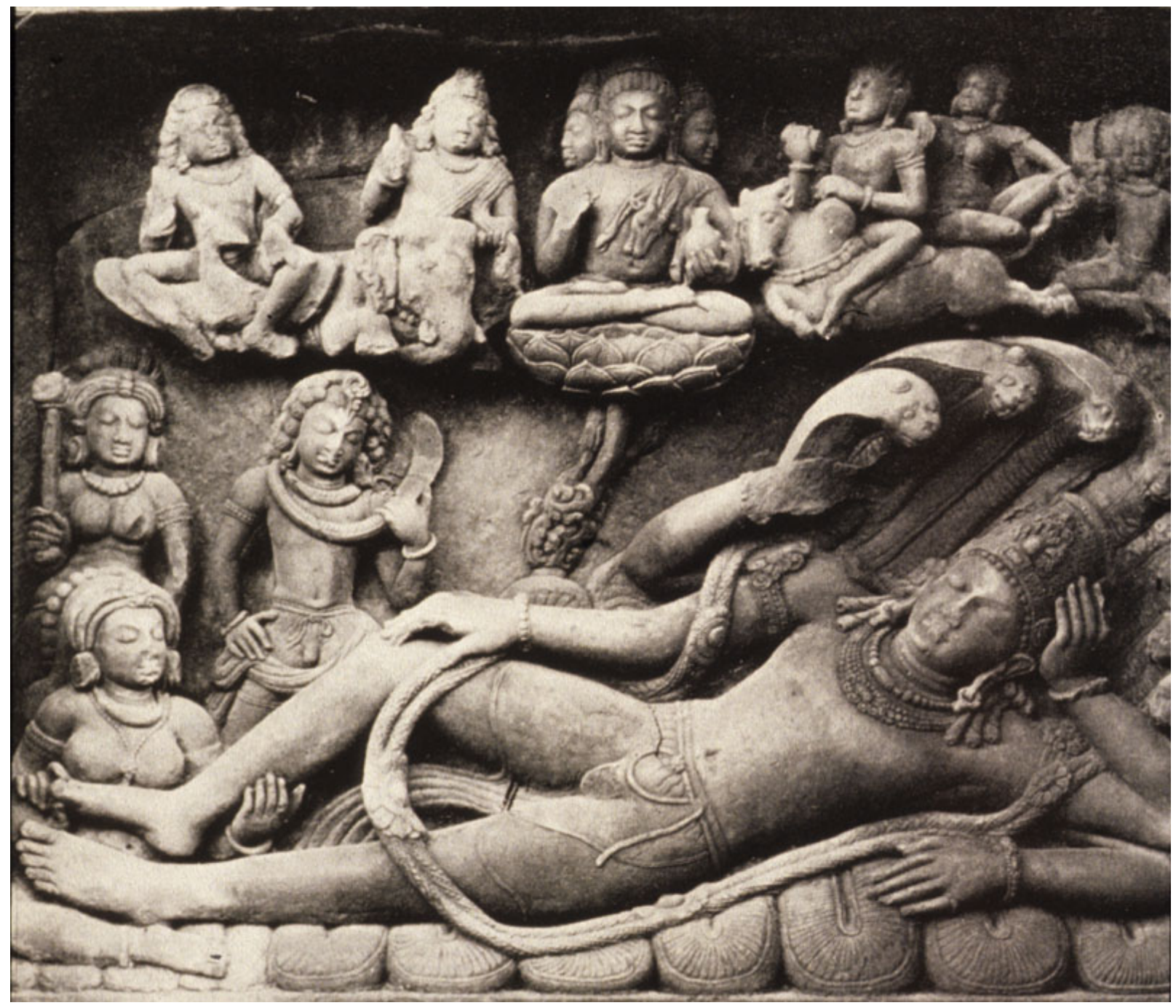

Figure 28

Panel of Vishnu and Brahma from the Vishnu Temple in Deogarh, India Gupta Architecture, 300-600 CE 


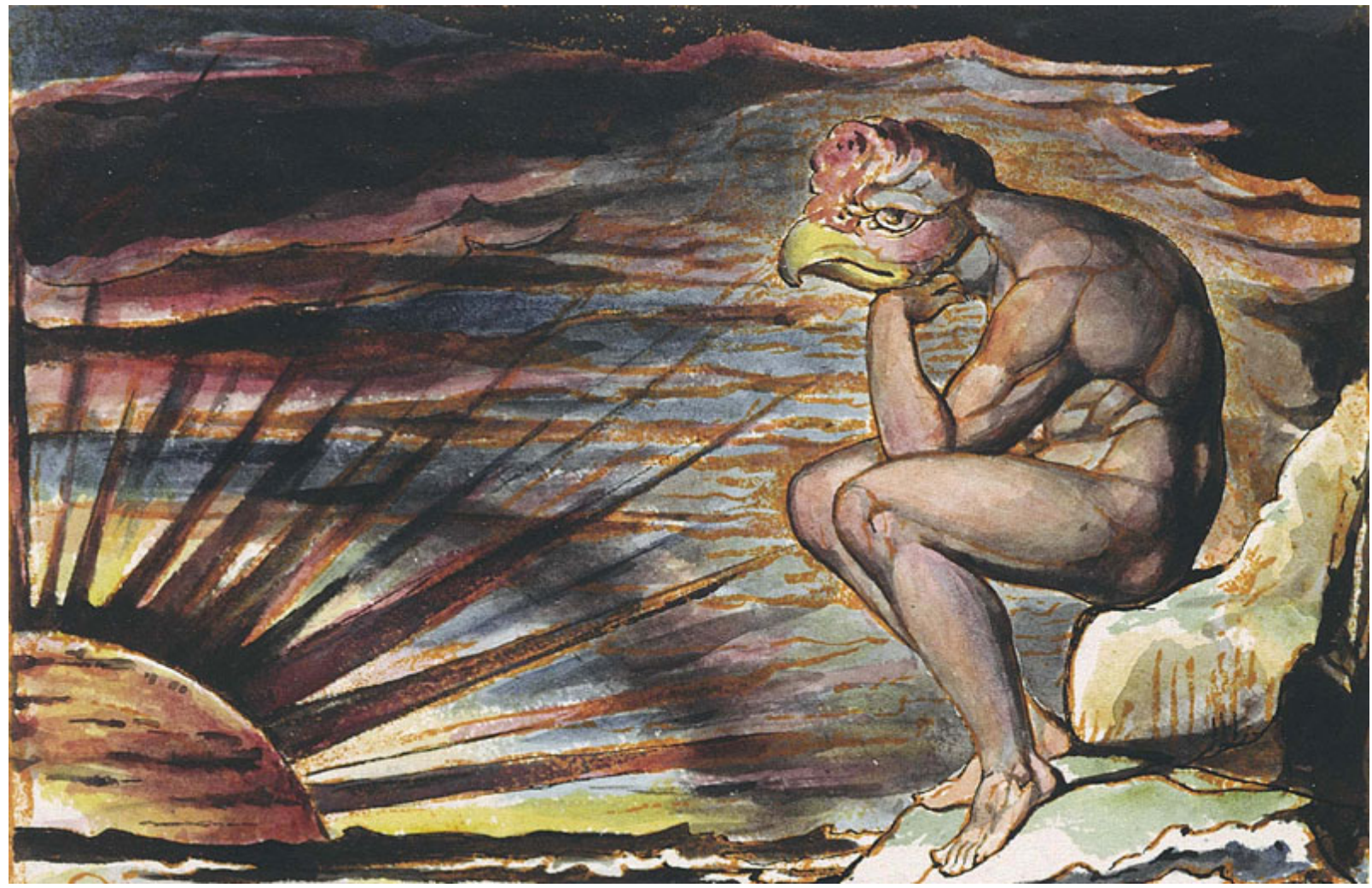

Figure 29

William Blake

Detail of Plate 78 of Jerusalem, the Emanation of the Giant Albion 1820 


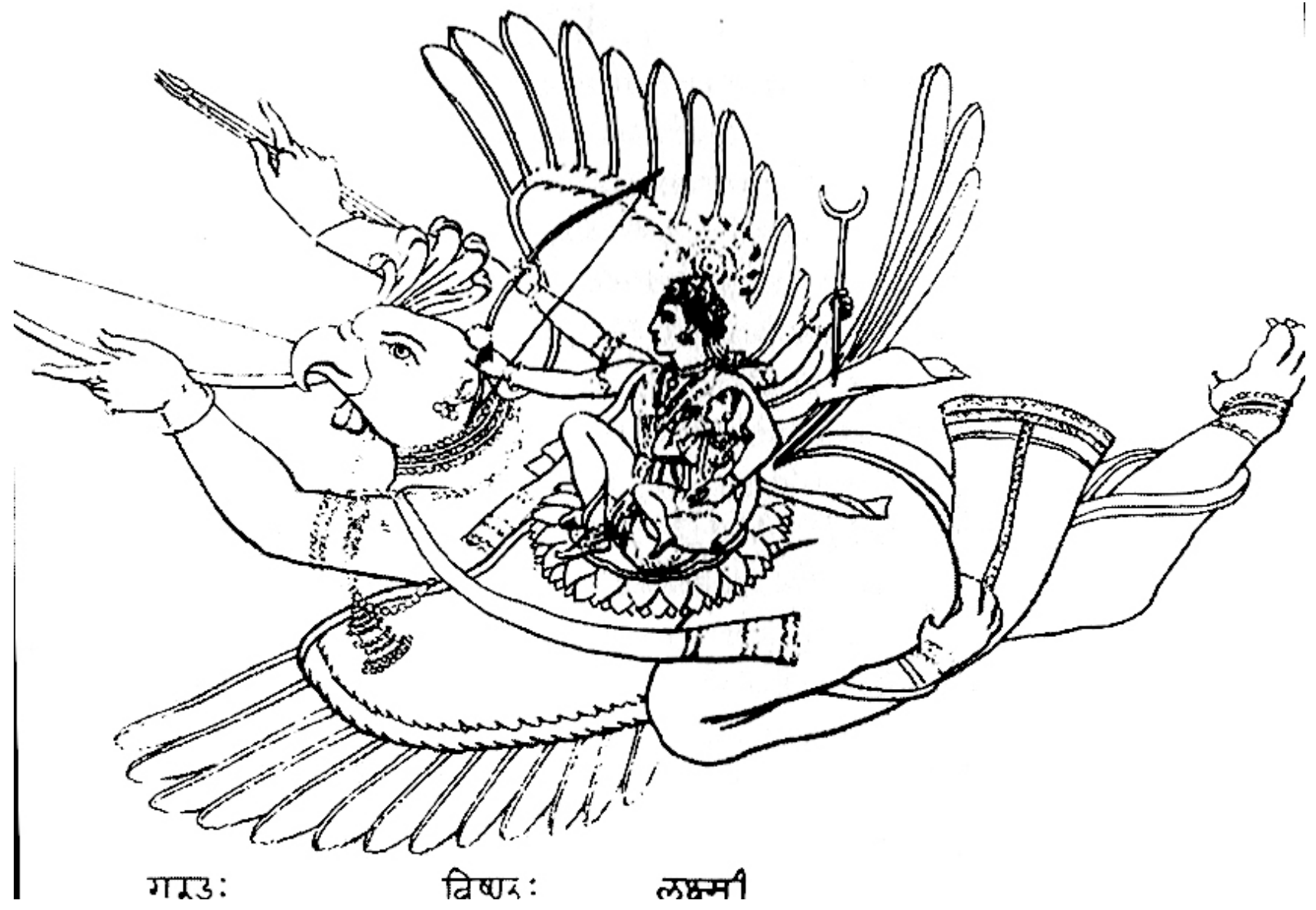

Figure 30

Moses Haughton

Garuda with Vishnu and Consort, from Moor's The Hindu Pantheon 


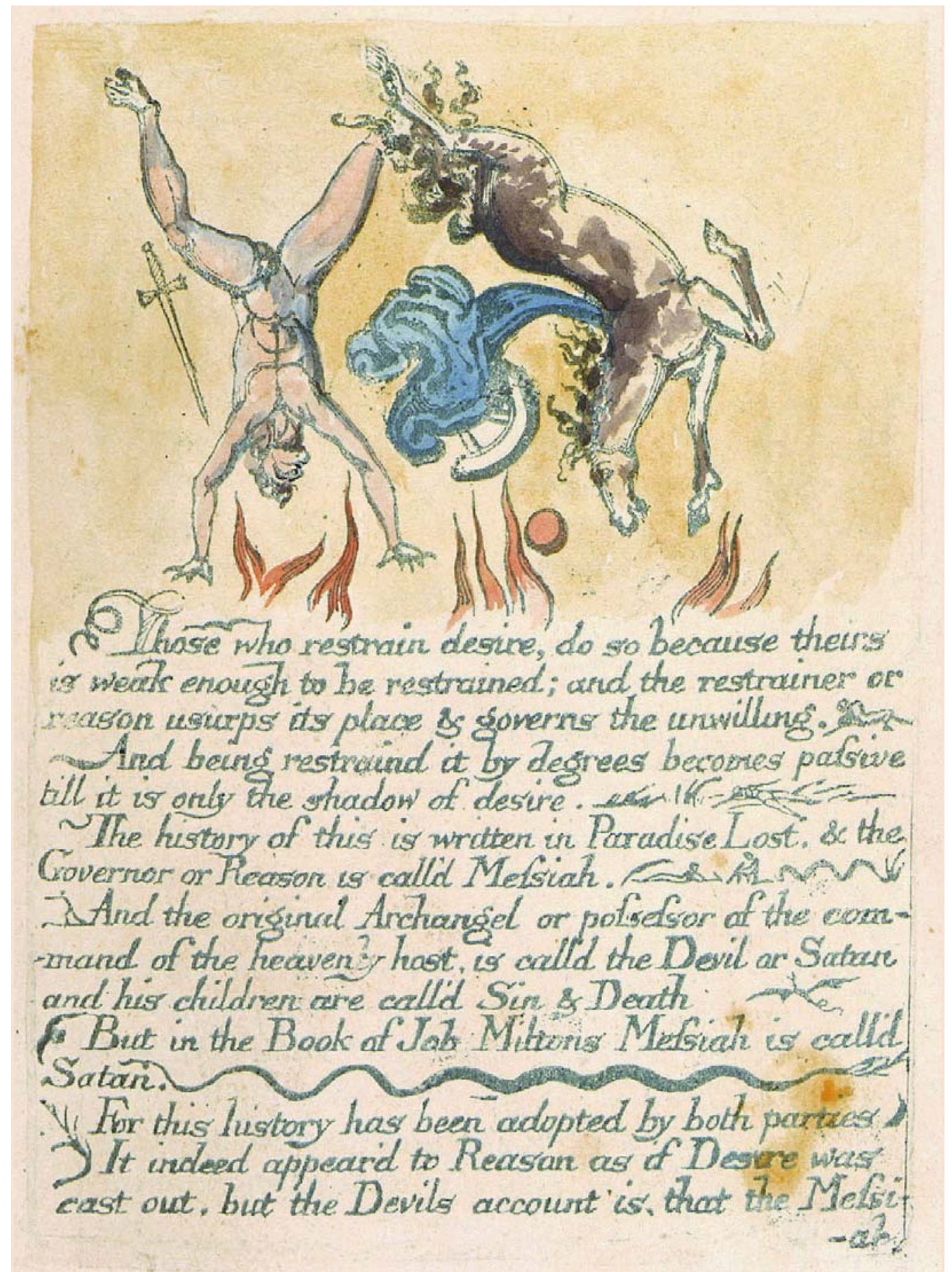

Figure 31

William Blake

Plate 5 from The Marriage of Heaven and Hell

1790 


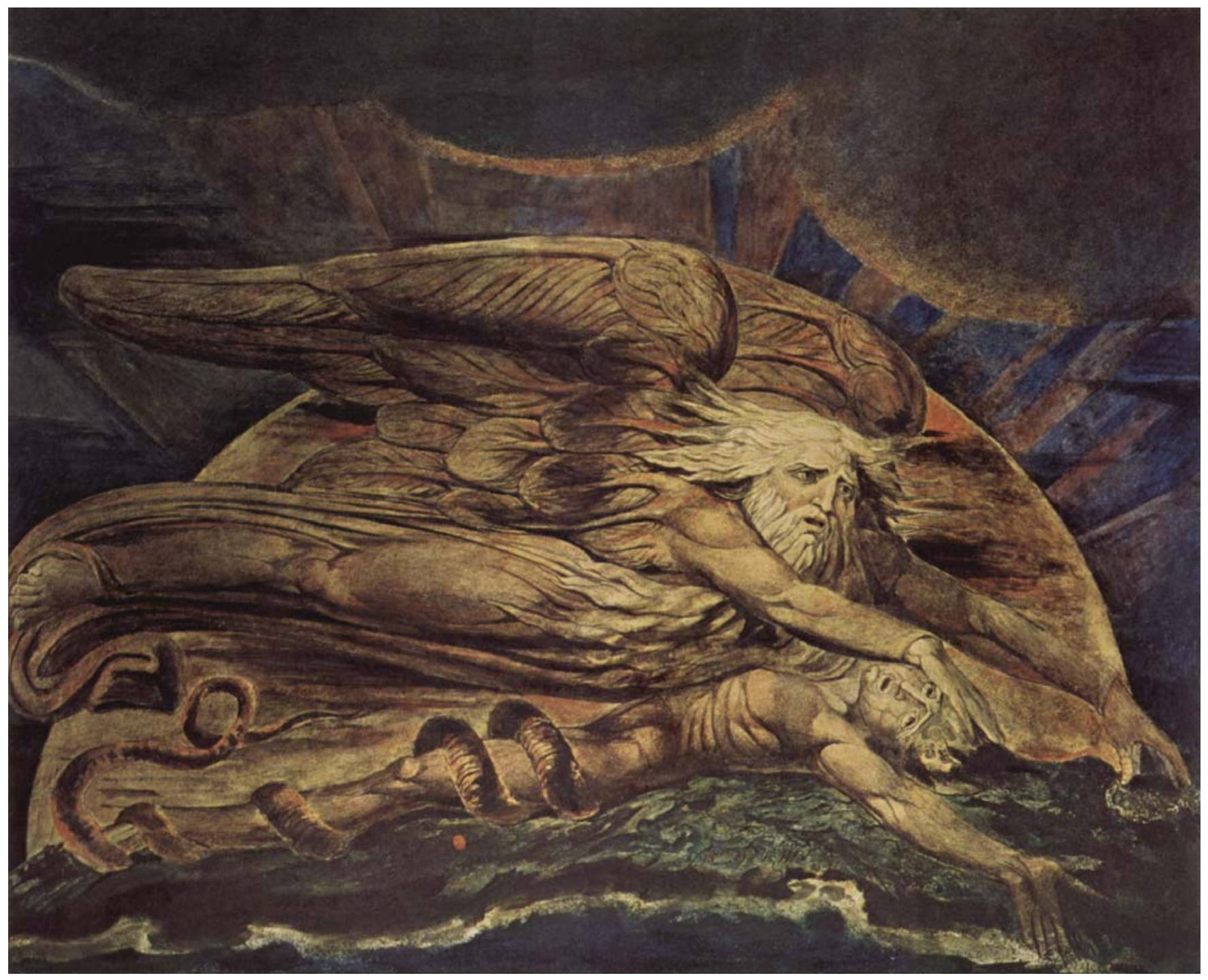

Figure 32

William Blake

Elohim Creating Adam

1795 


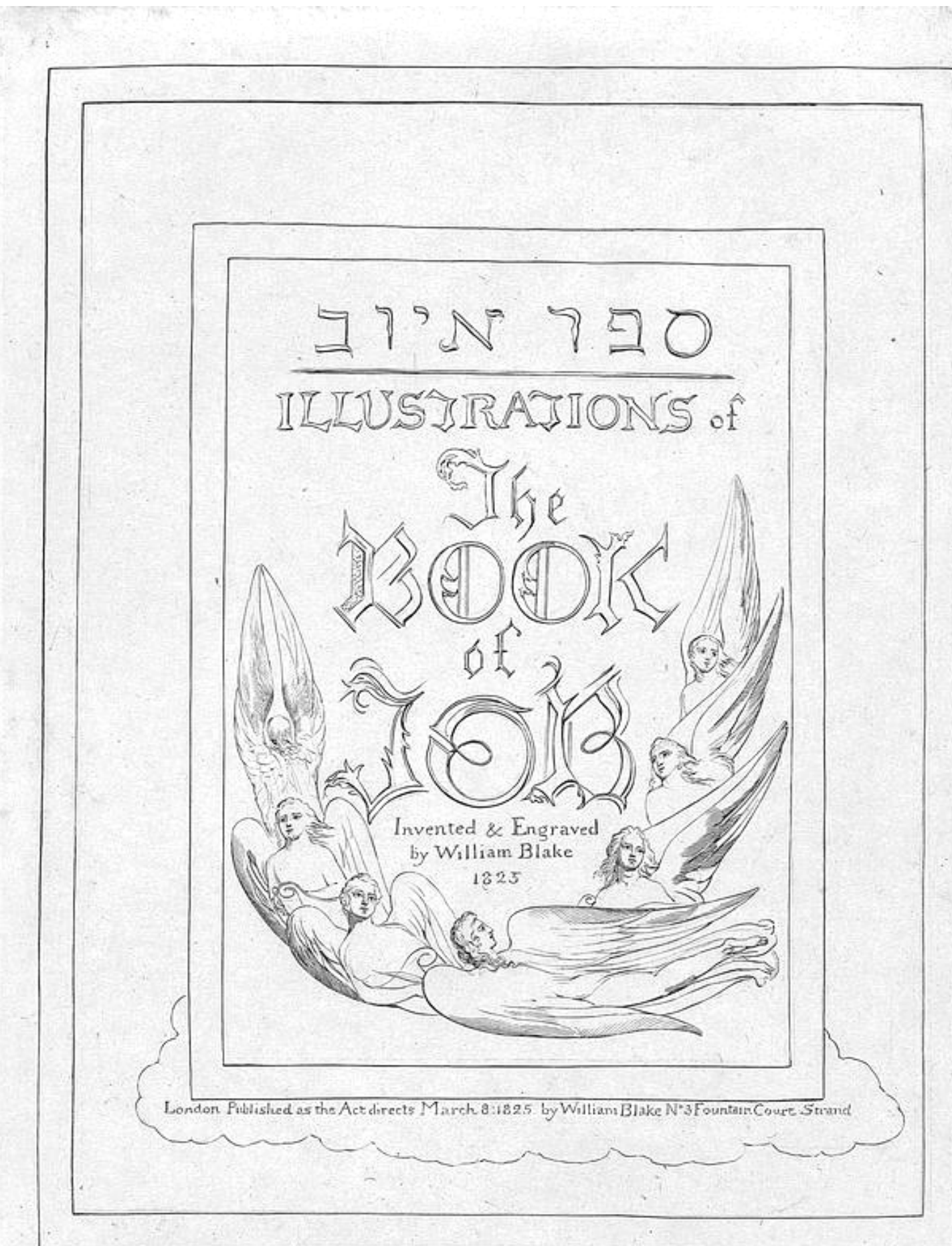

Figure 33

William Blake

Frontispiece, The Illustrations of the Book of Job

1825 


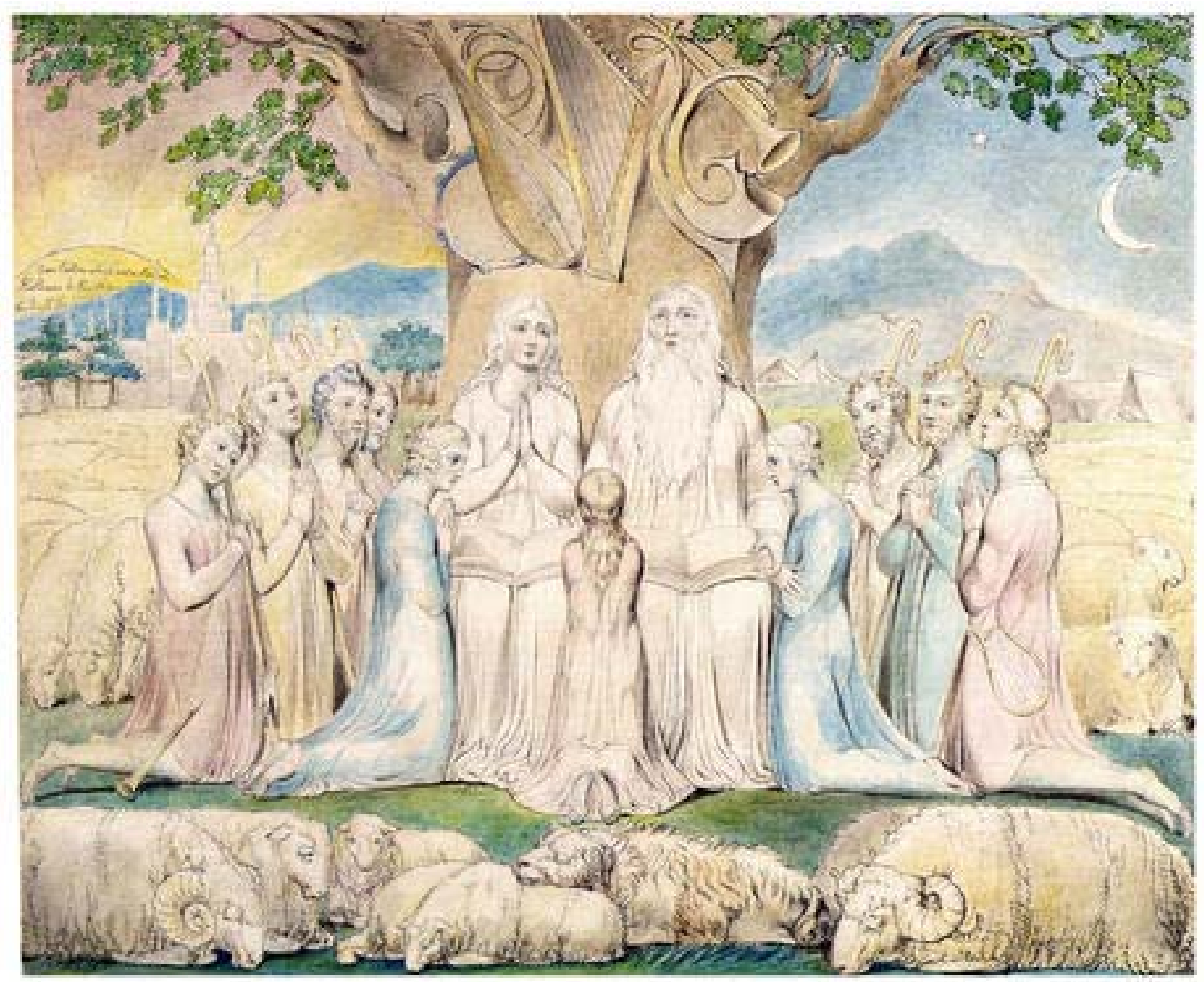

Figure 34

William Blake

The Illustrations of the Book of Job, "Job and his Family"

1825 


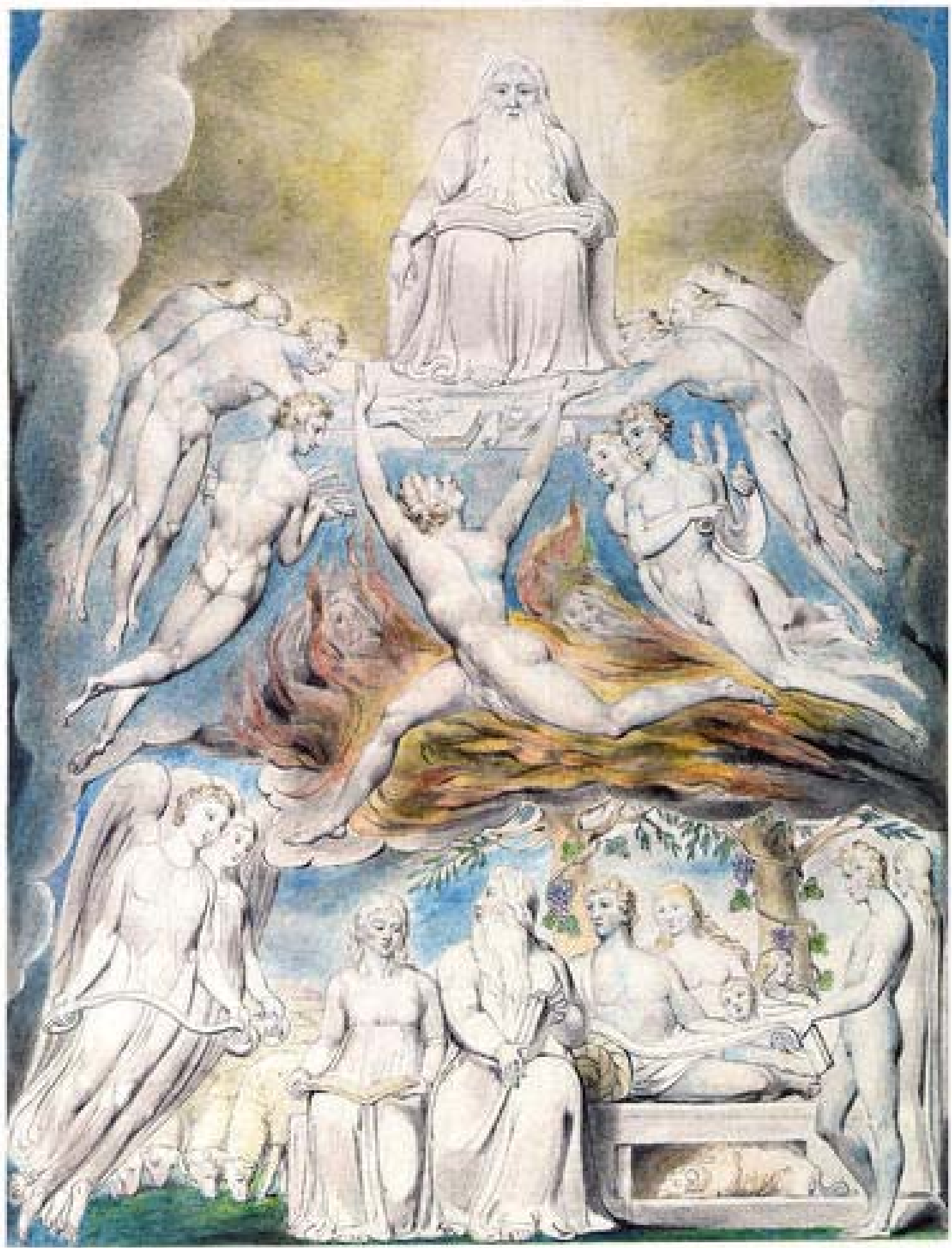

Figure 35

William Blake

The Illustrations of the Book of Job, "Satan before the Throne of God" 1825 


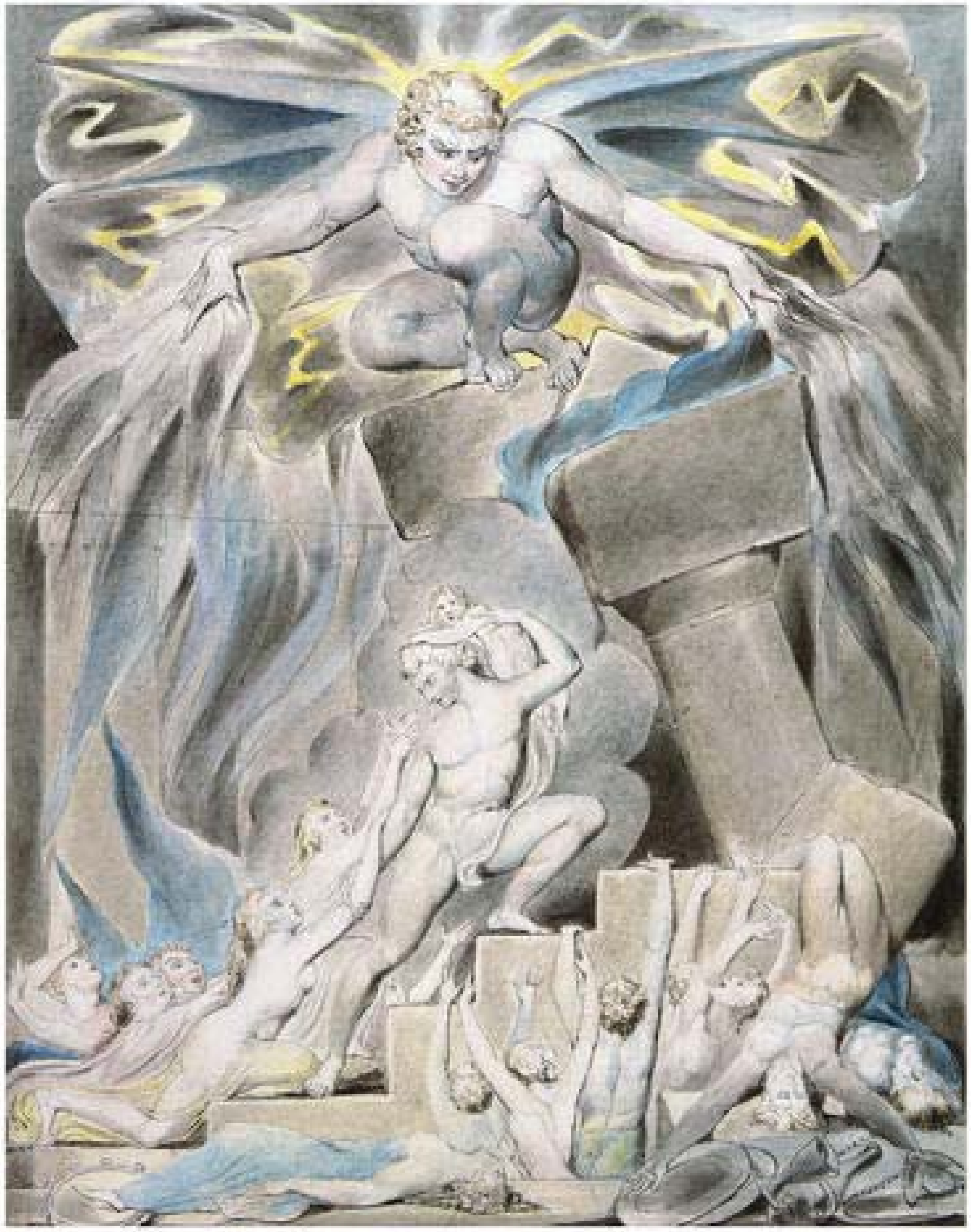

Figure 36

William Blake

The Illustrations of the Book of Job, "The Destruction of Job's Sons," 


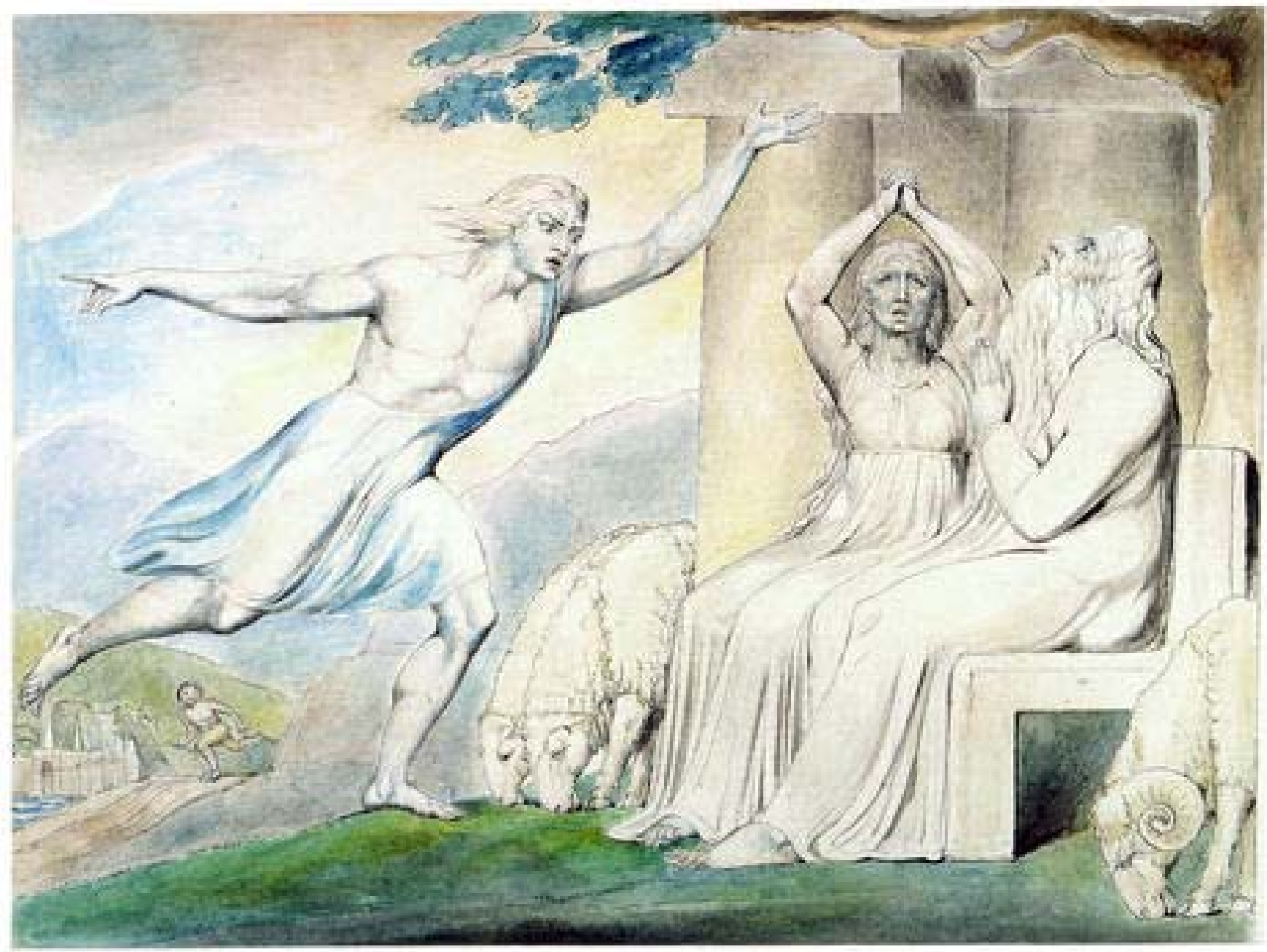

Figure 37

William Blake

The Illustrations of the Book of Job, "The Messengers tell Job of the Misfortunes that have Befallen him" 


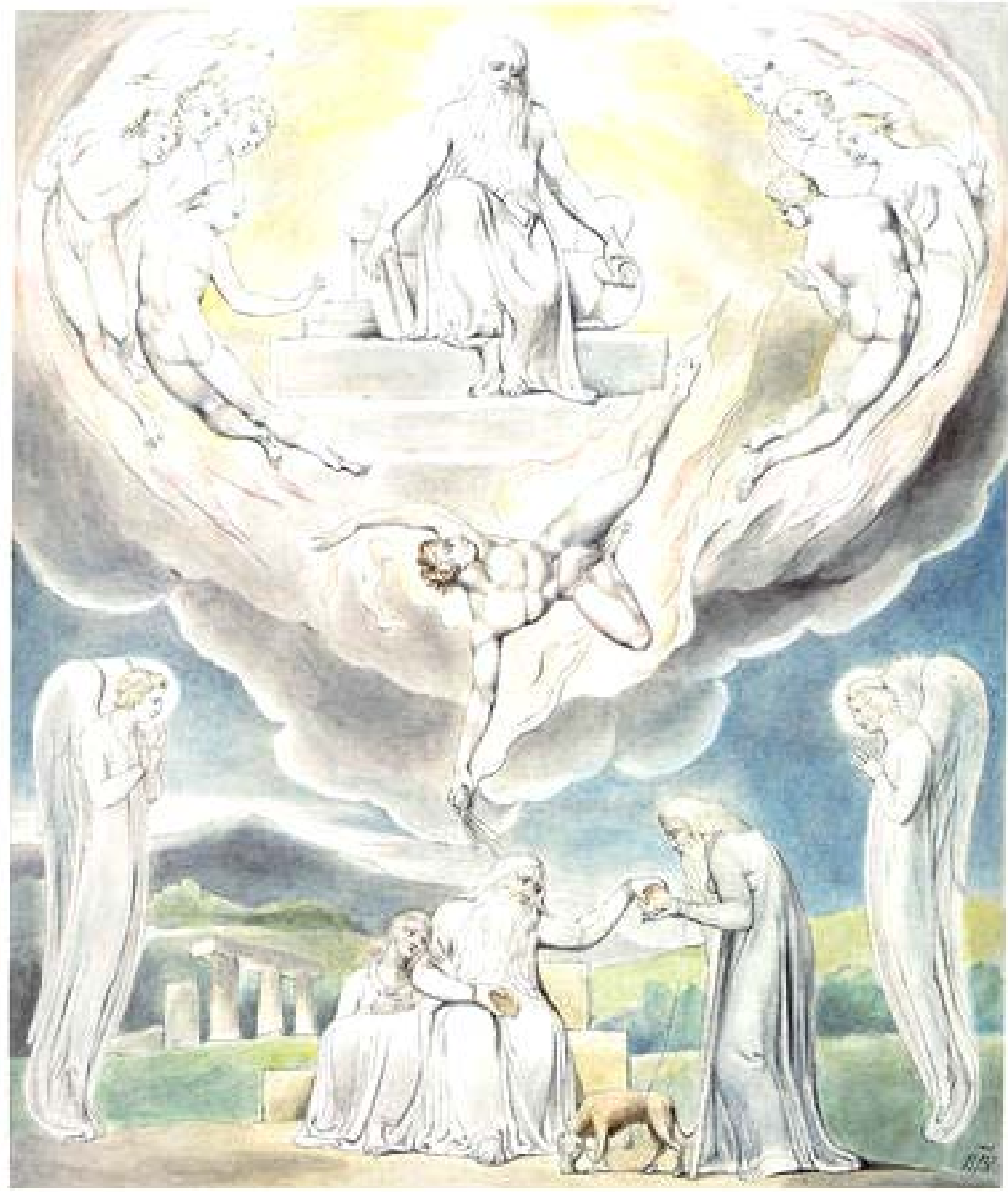

Figure 38

William Blake

The Illustrations of the Book of Job, "Satan going forth from the Presence of the Lord" 1825 


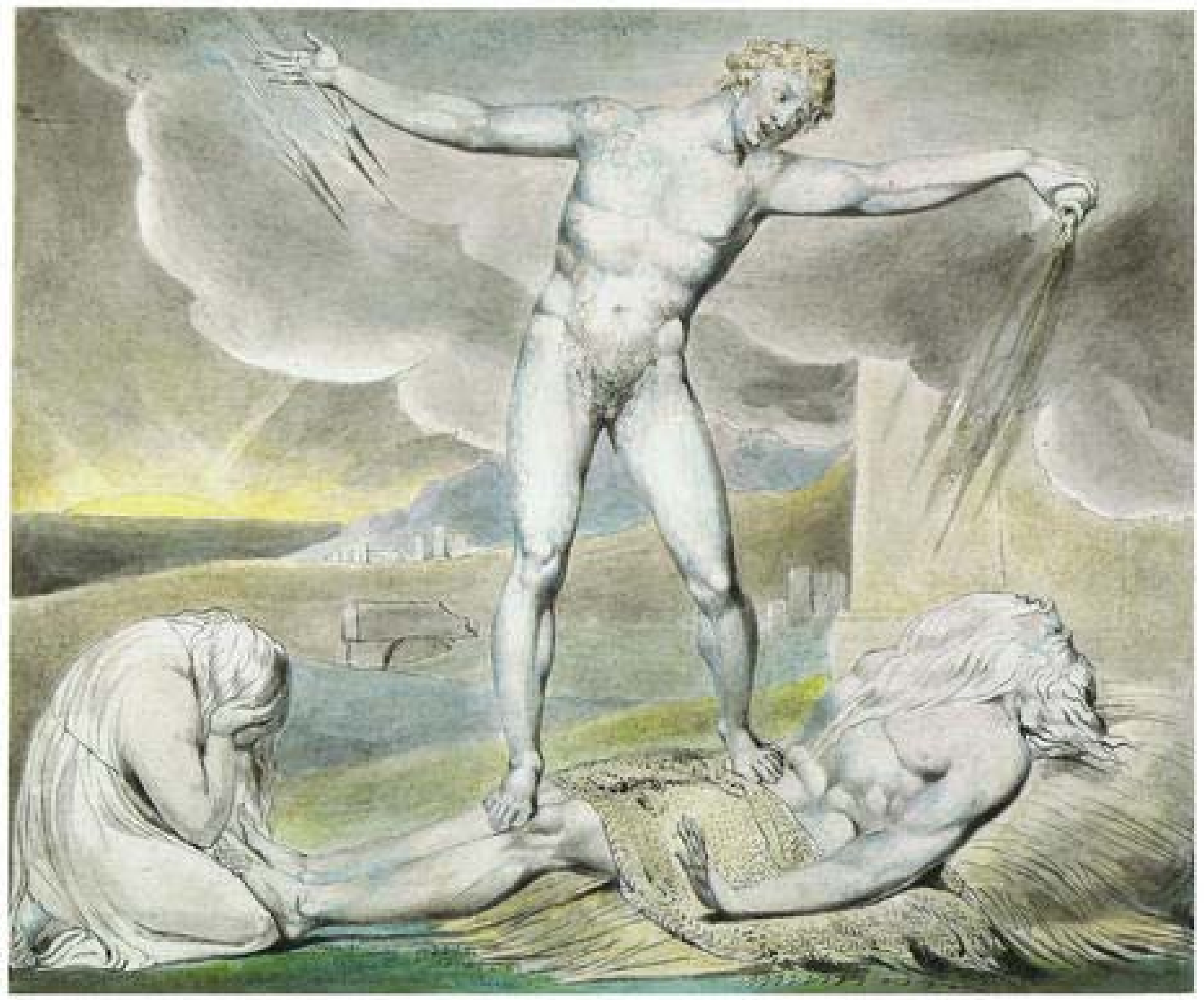

Figure 39

William Blake

The Illustrations of the Book of Job, "Satan smiting Job with Boils" 1825 


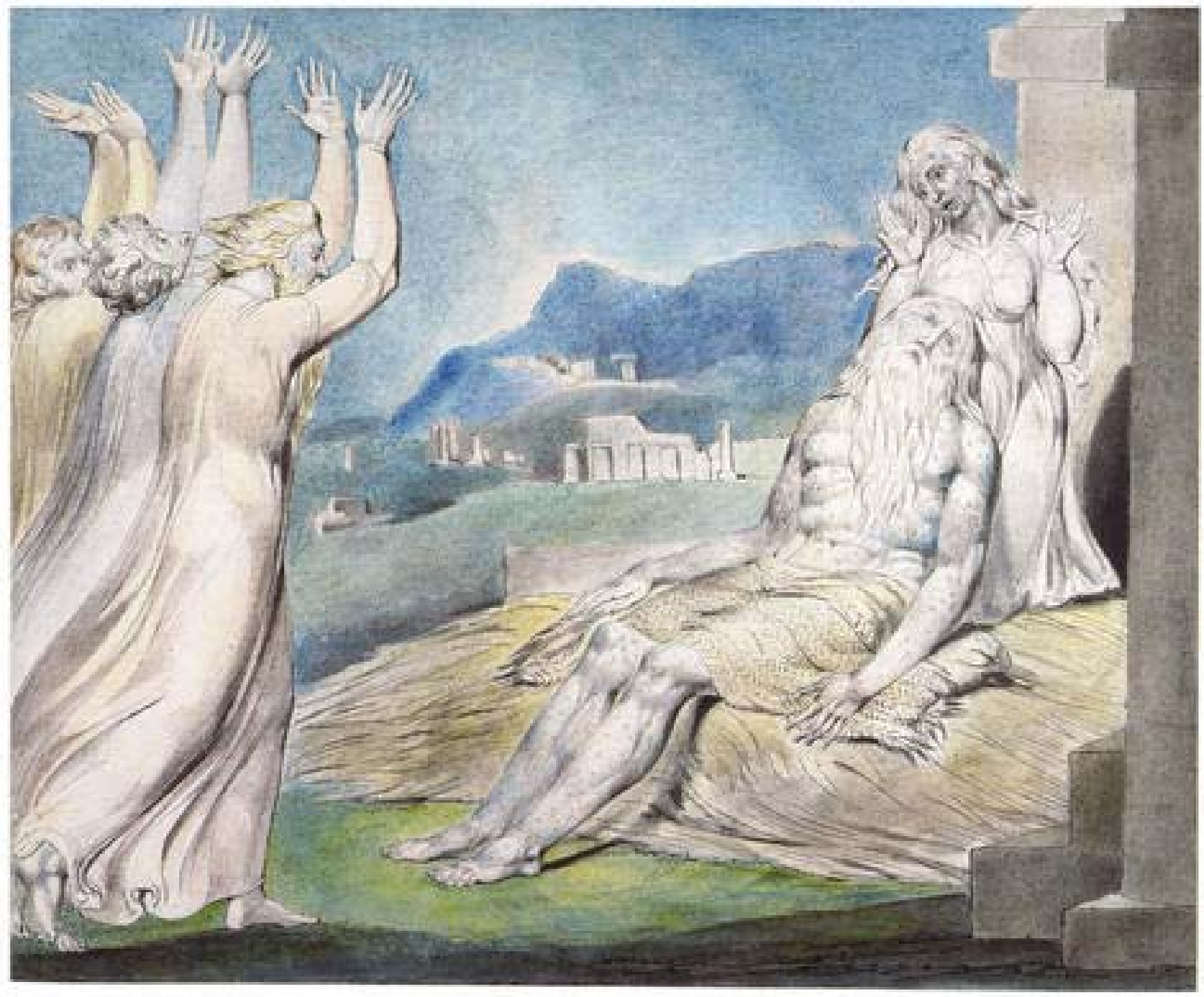

Figure 40

William Blake

The Illustrations of the Book of Job, "Job's Comforters" 1825 


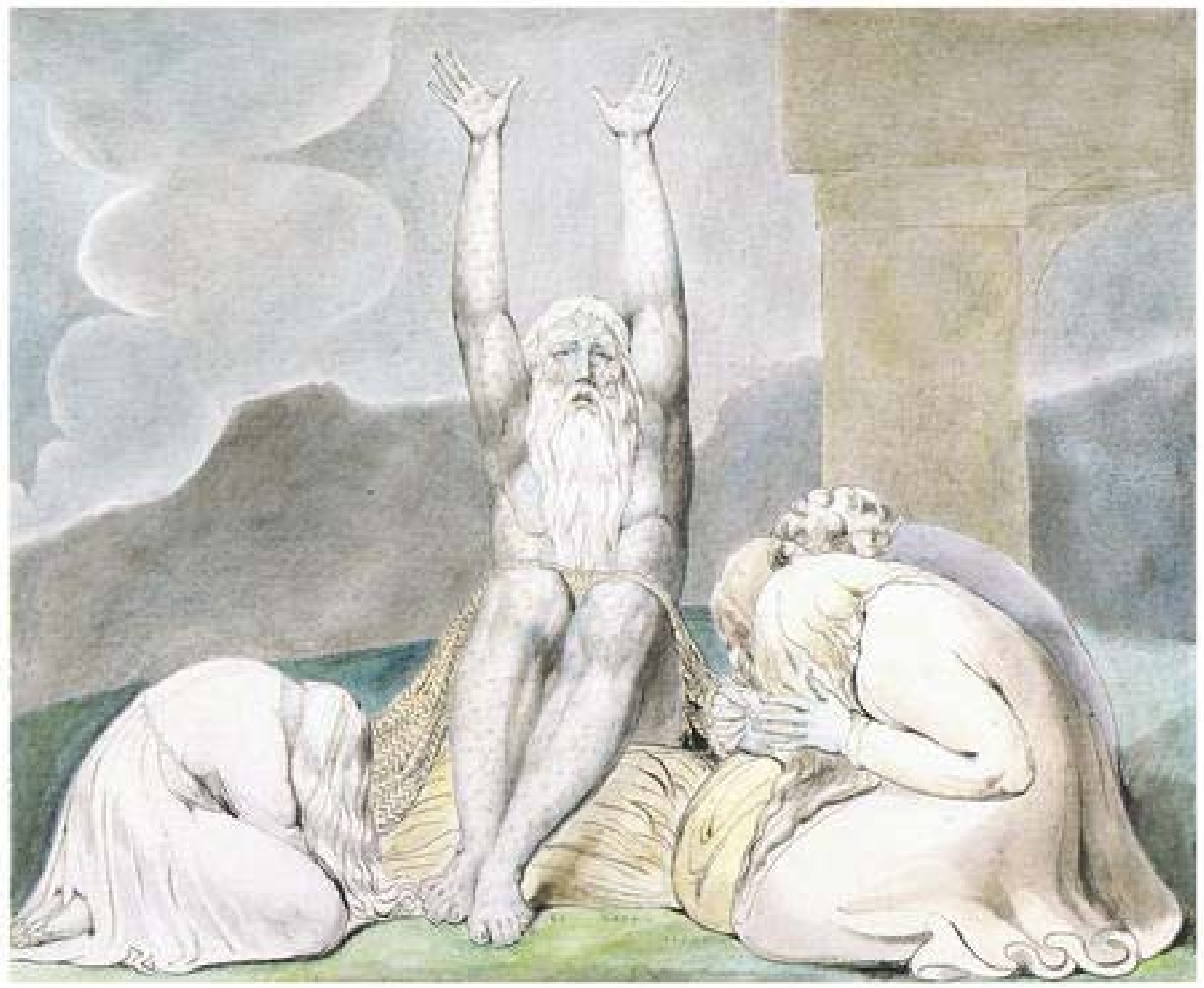

Figure 41

William Blake

The Illustrations of the Book of Job, "Job's Despair"

1825 


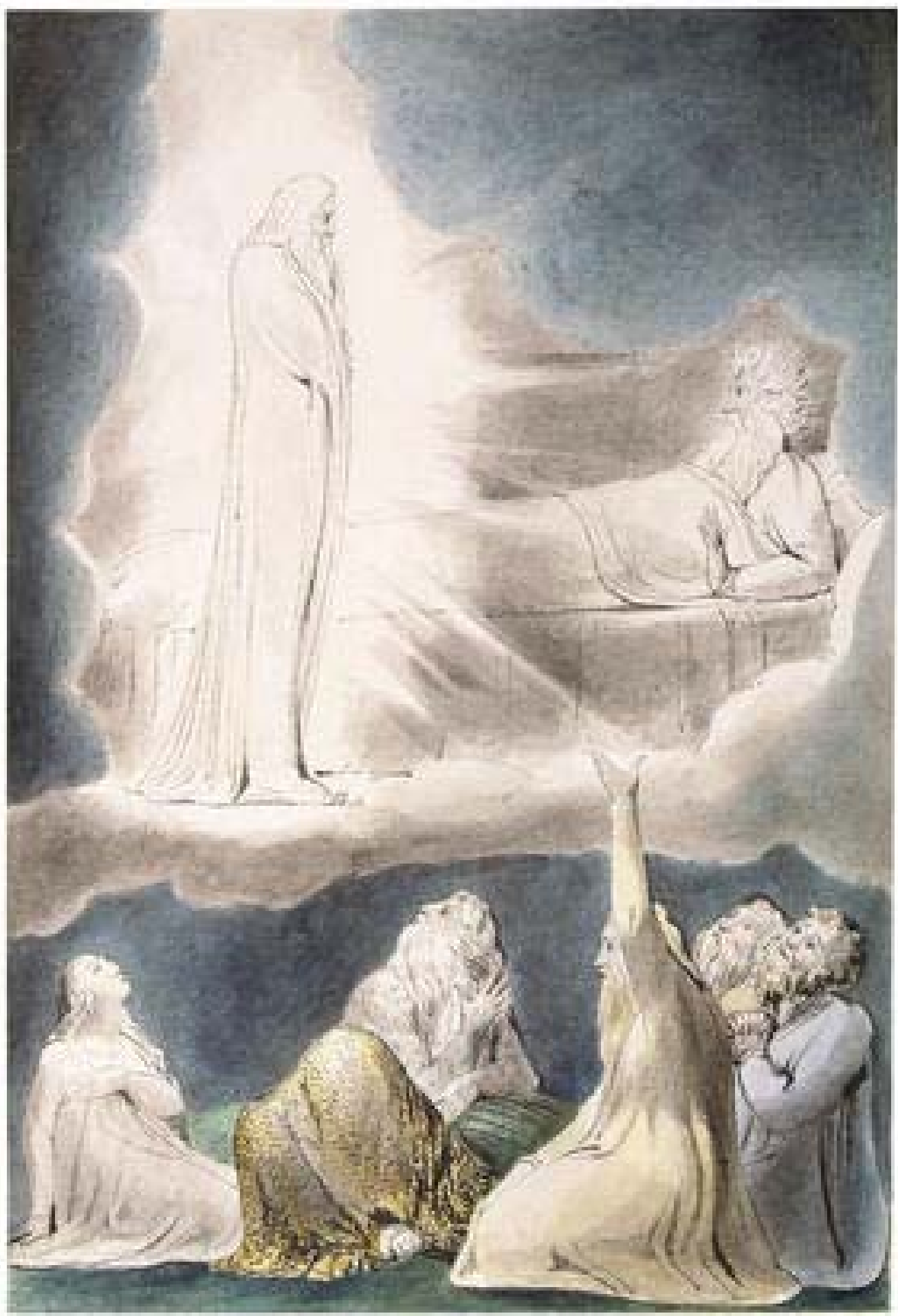

Figure 42

William Blake

The Illustrations of the Book of Job, "The Vision of Eliphaz"

1825 


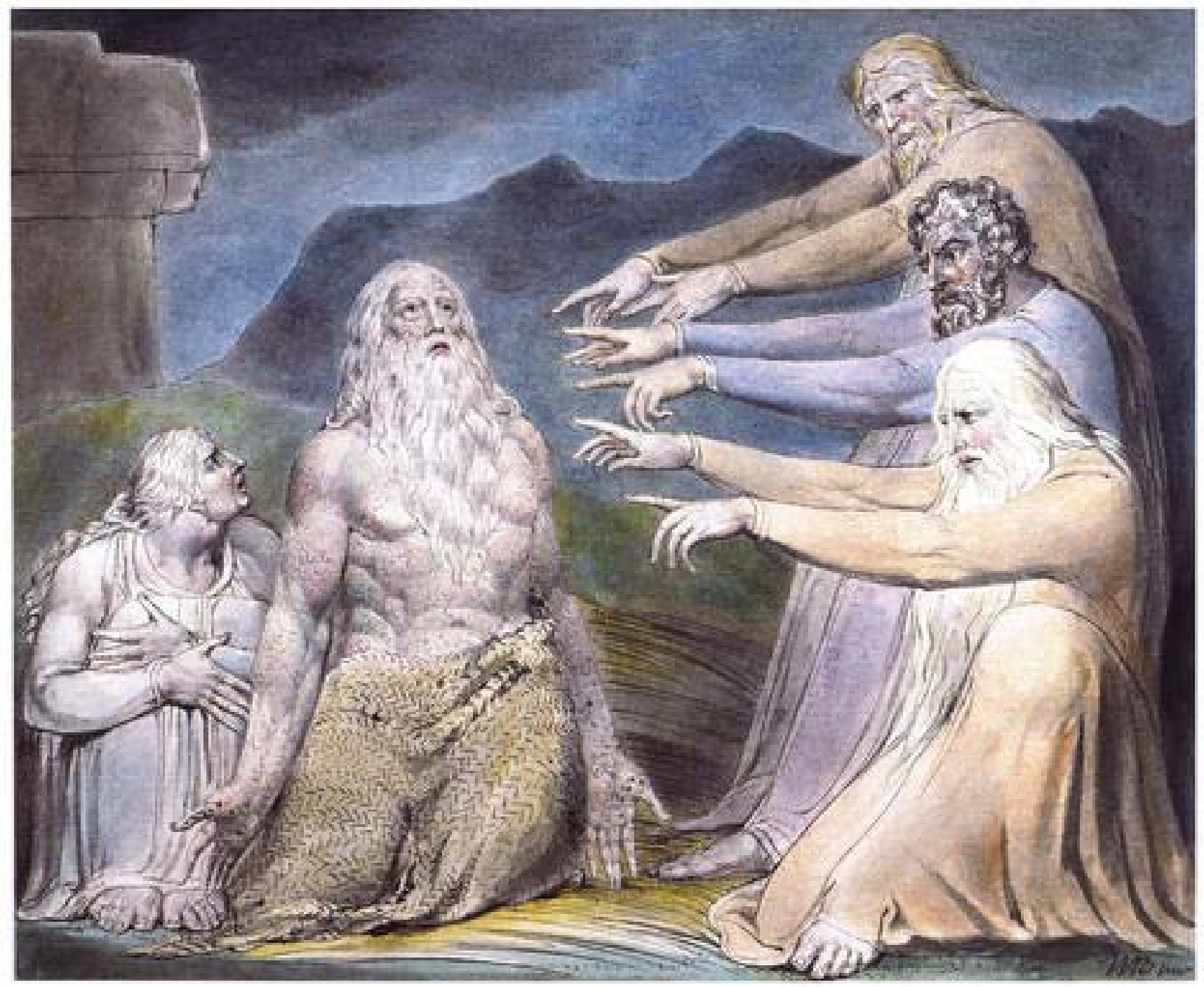

Figure 43

William Blake

The Illustrations of the Book of Job, "Job rebuked by his Friends"

1825 


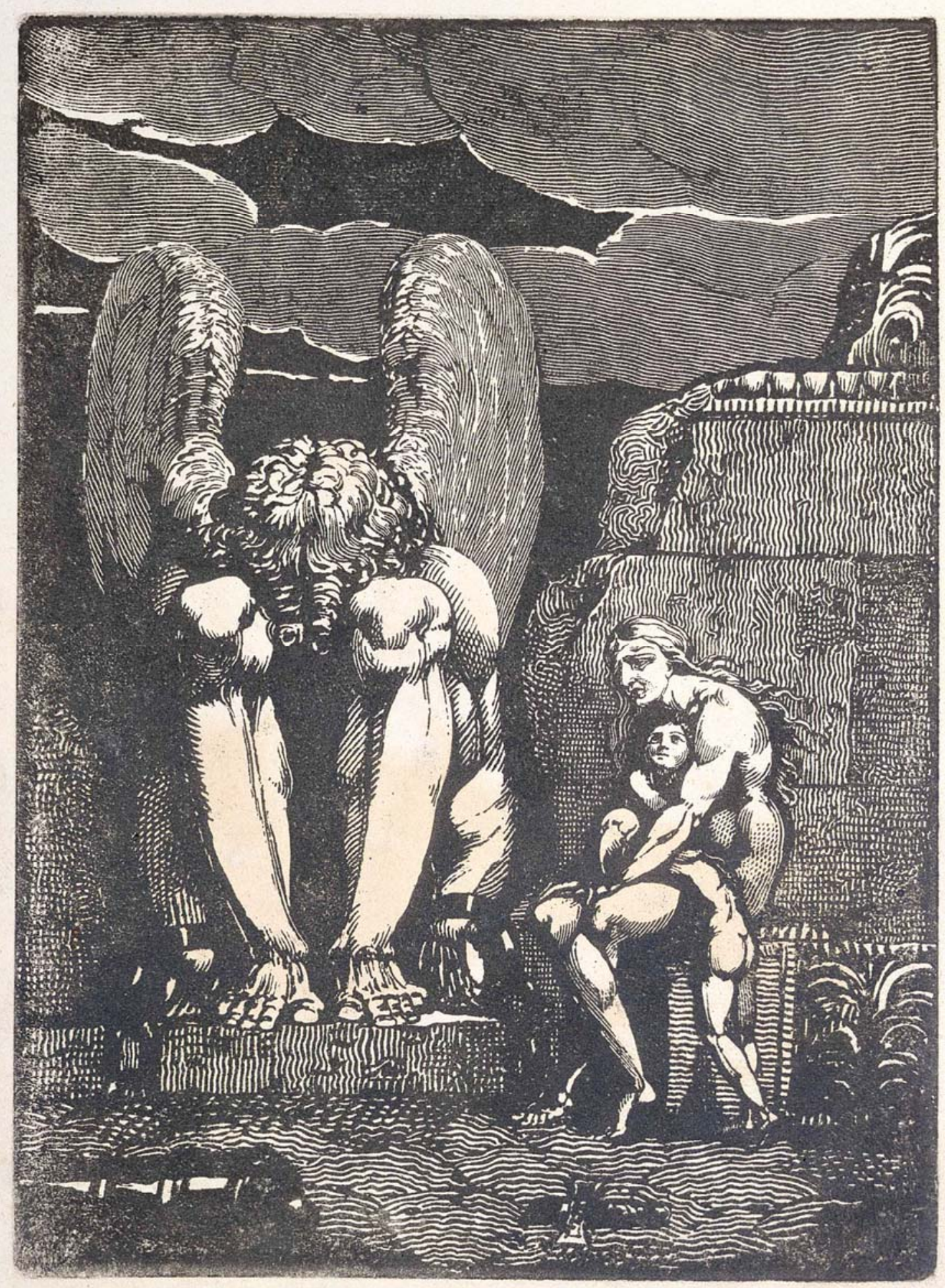

Figure 44

William Blake

Frontispiece of America, a Prophecy

1793 


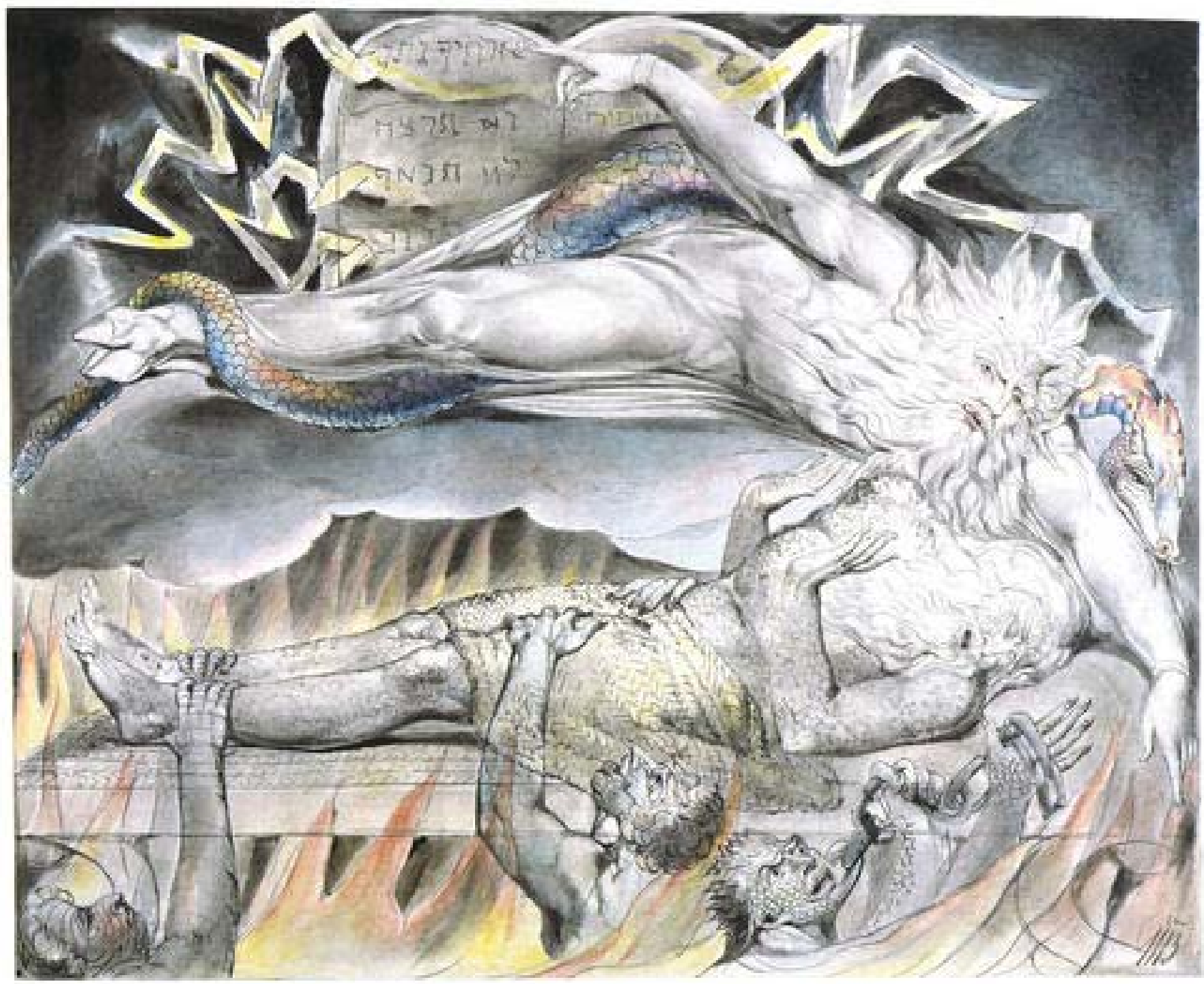

Figure 45

William Blake

The Illustrations of the Book of Job, "Job's Evil Dreams"

1825 


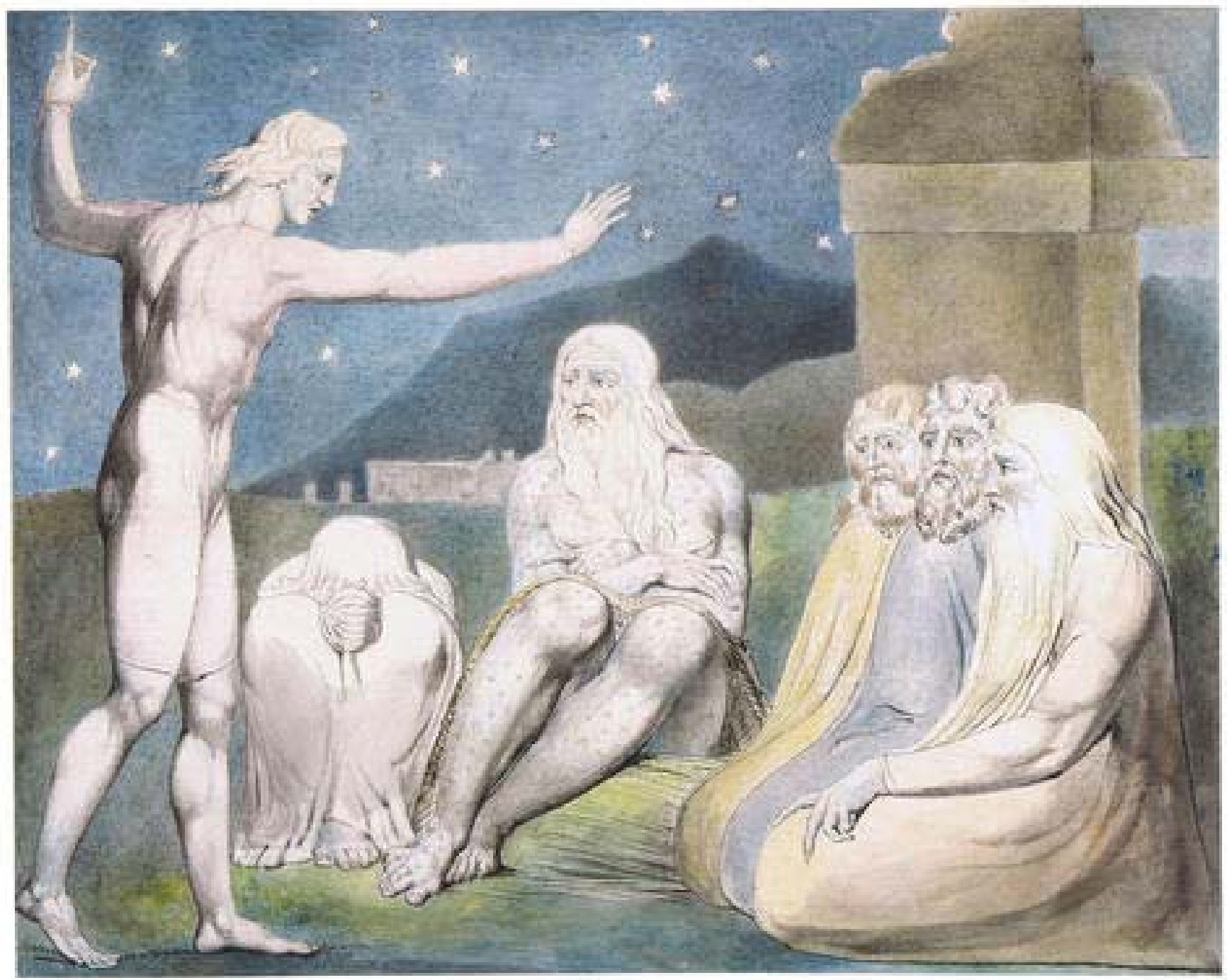

Figure 46

William Blake

The Illustrations of the Book of Job, "The Wrath of Elihu" 1825 


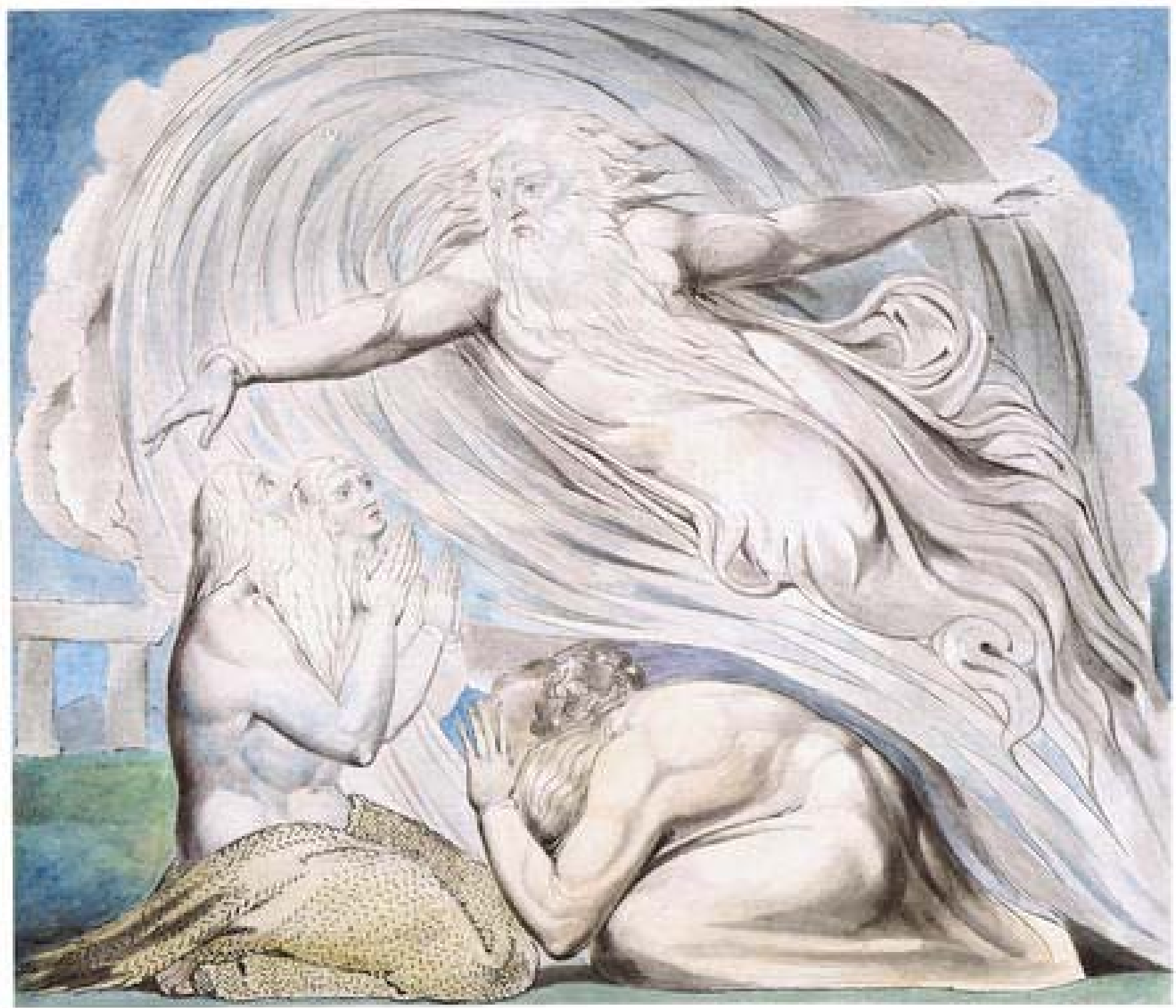

Figure 47

William Blake

The Illustrations of the Book of Job, "The Lord answering Job out of the Whirlwind" 1825 


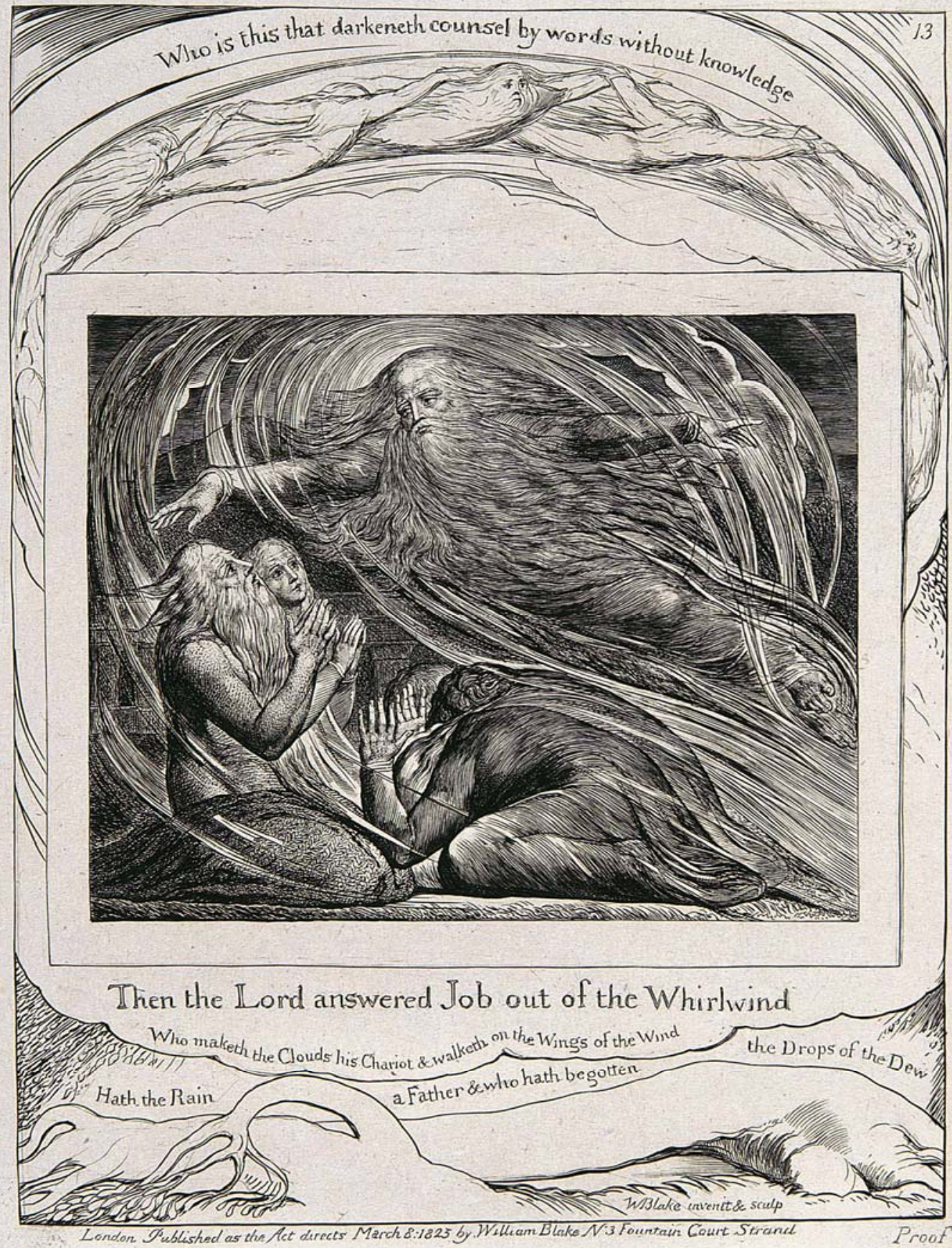

Figure 48

William Blake

The Illustrations of the Book of Job, "The Lord answering Job out of the Whirlwind," print, 1825 


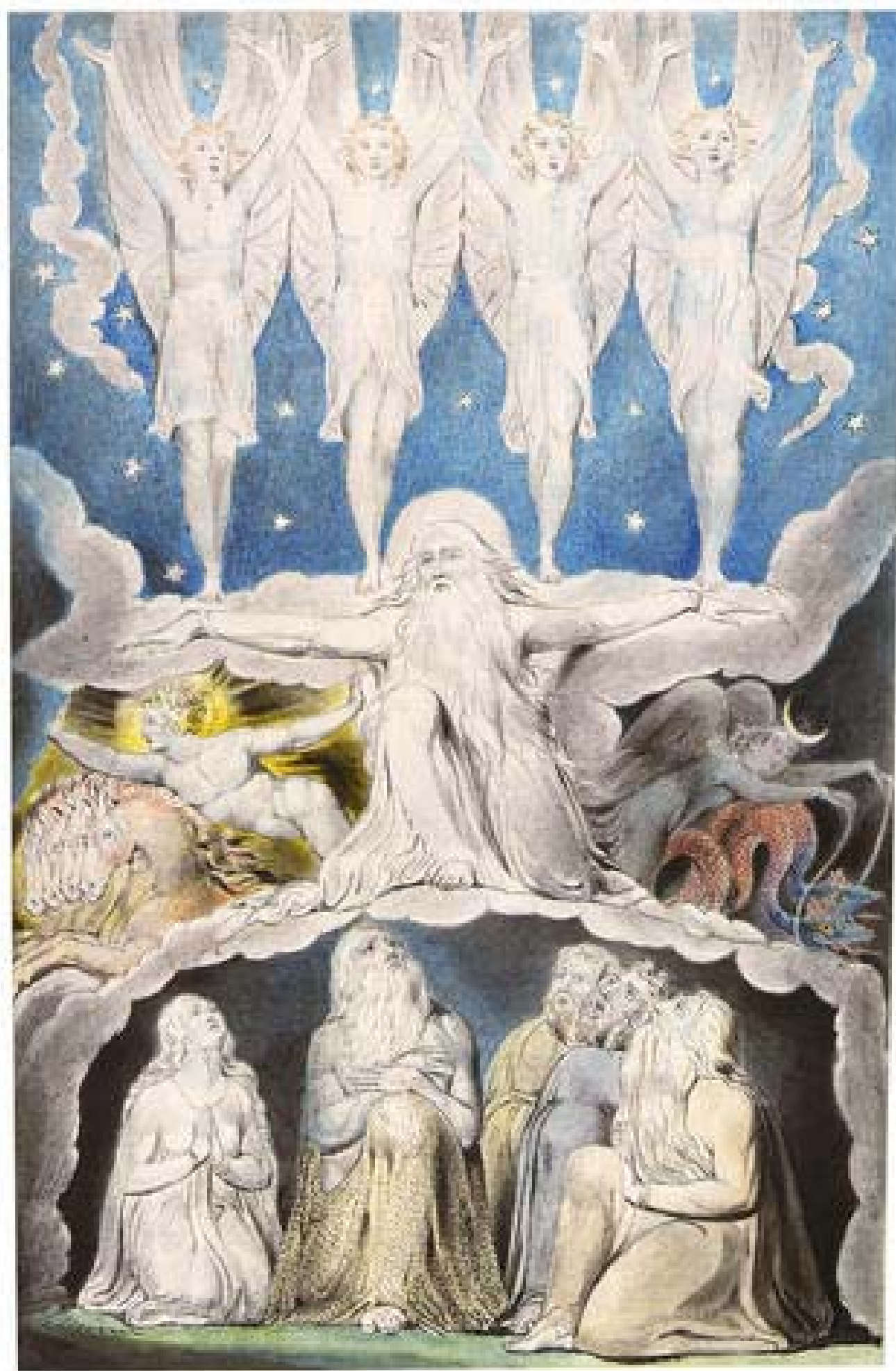

Figure 49

William Blake

The Illustrations of the Book of Job, "The Creation" 


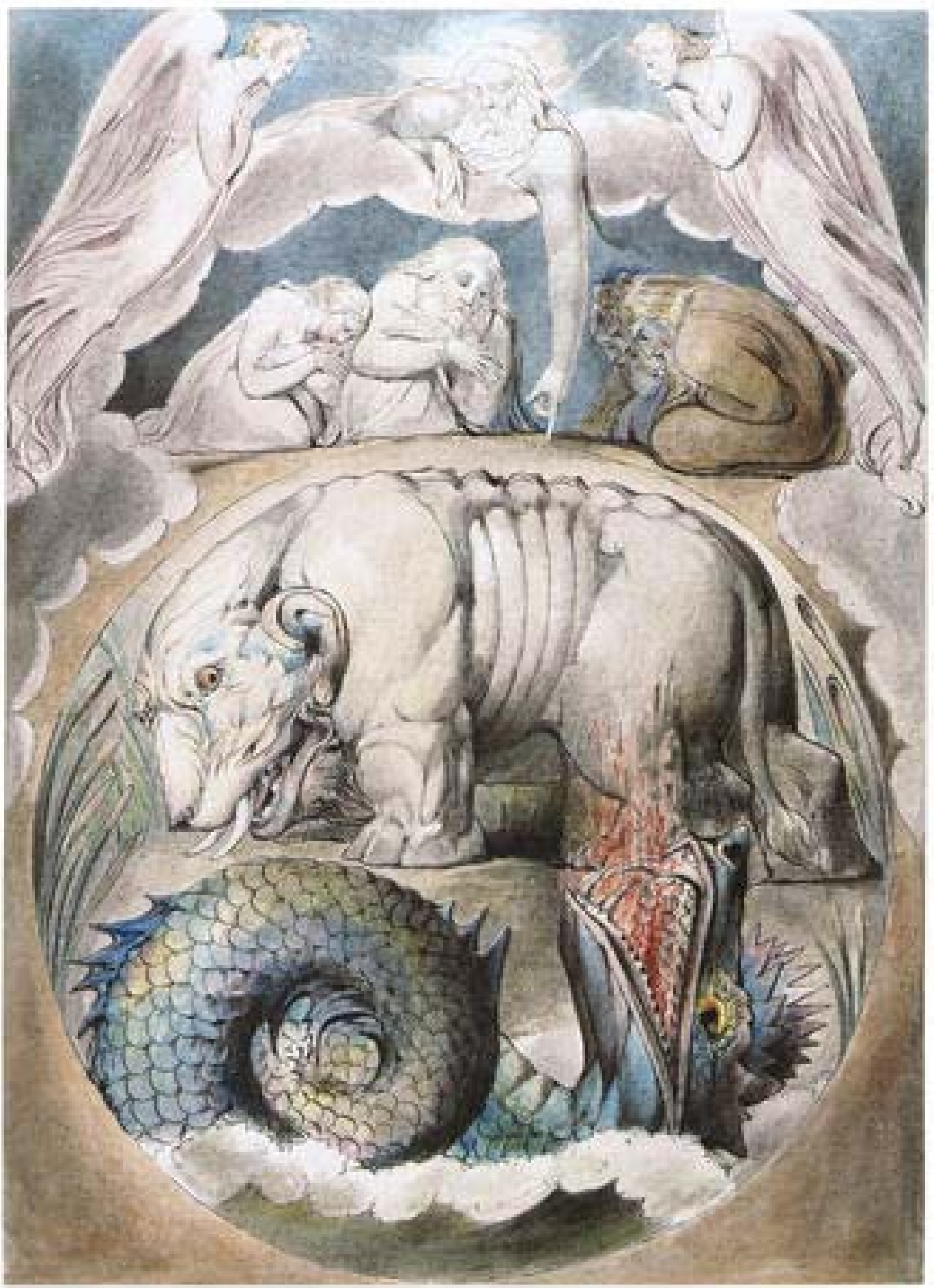

Figure 50

William Blake

The Illustrations of the Book of Job, "Behemoth and Leviathan" 1825 


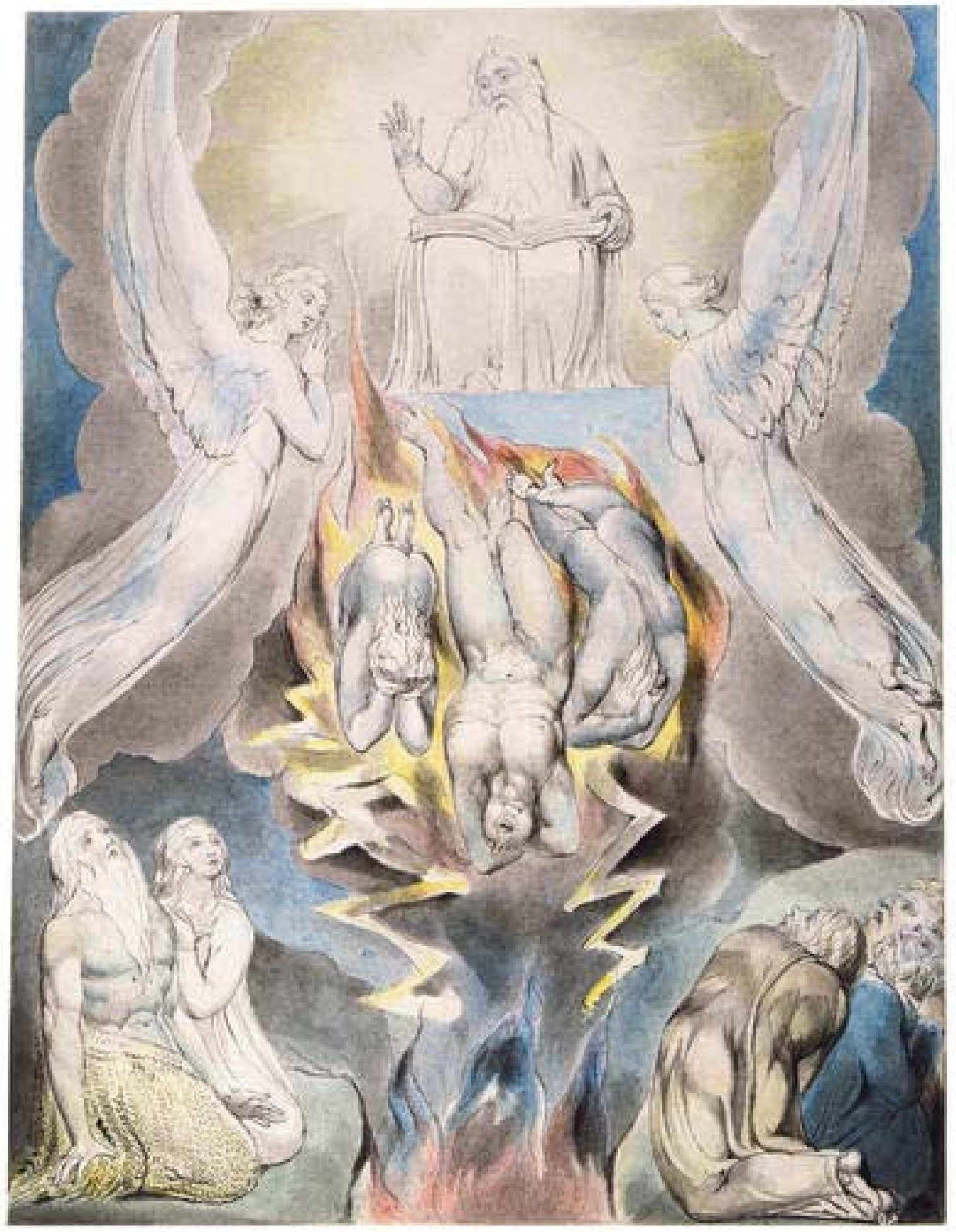

Figure 51

William Blake

The Illustrations of the Book of Job, "The Fall of Satan" 1825 


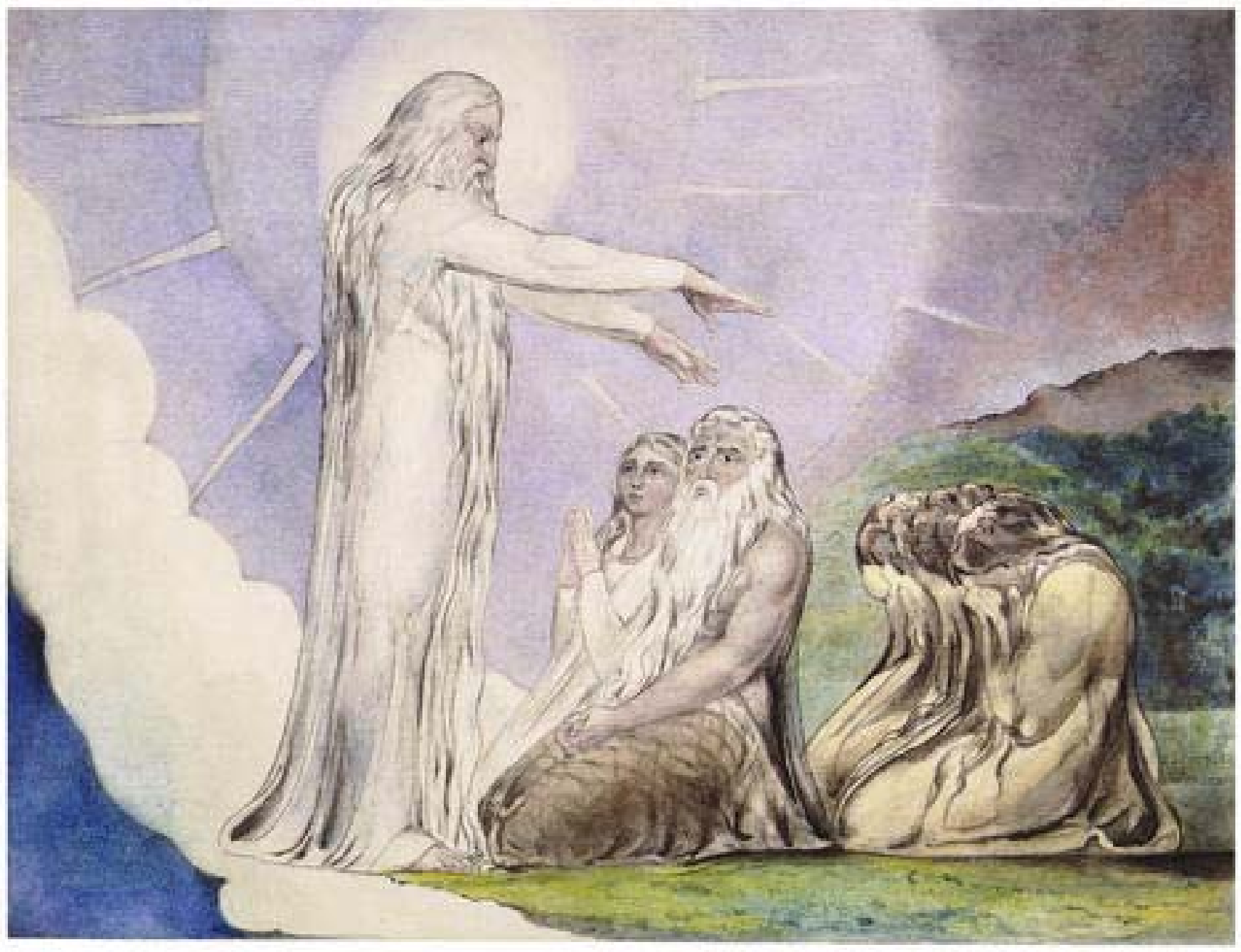

Figure 52

William Blake

The Illustrations of the Book of Job, "The Vision of God" 1825 


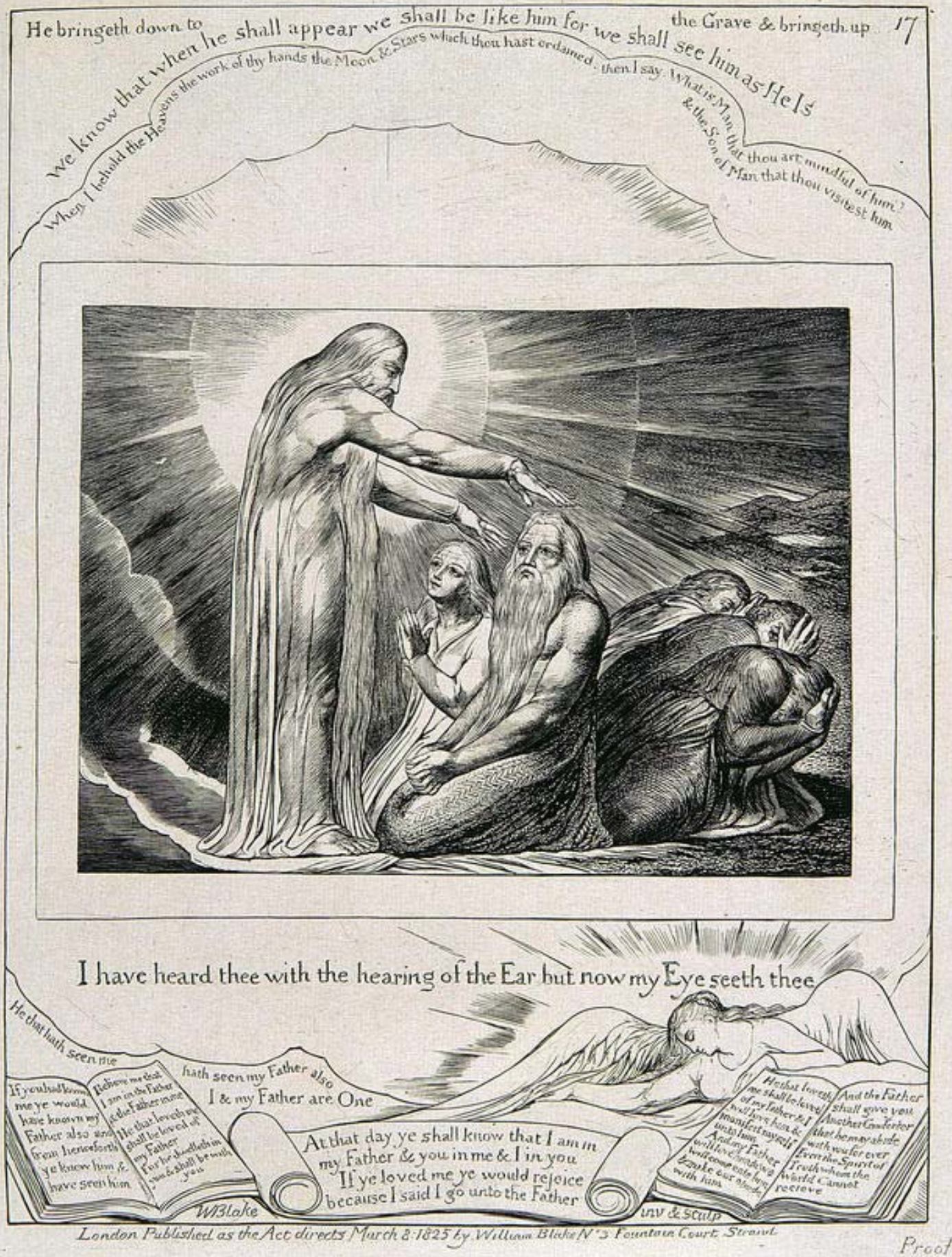

Figure 53

William Blake

The Illustrations of the Book of Job, "The Vision of God"

Print 1825 


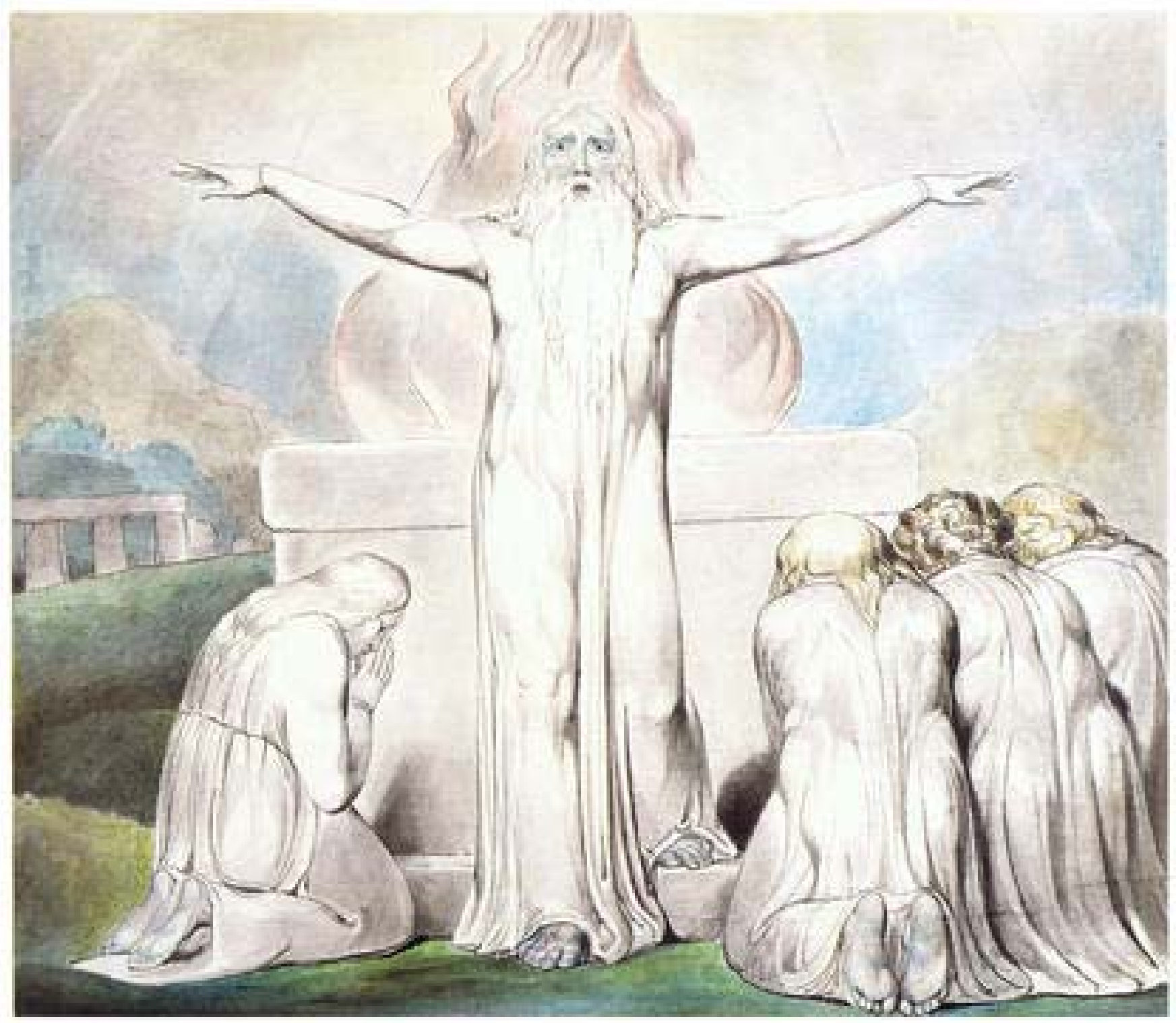

Figure 54

William Blake

The Illustrations of the Book of Job, "Job's Sacrifice"

1825 


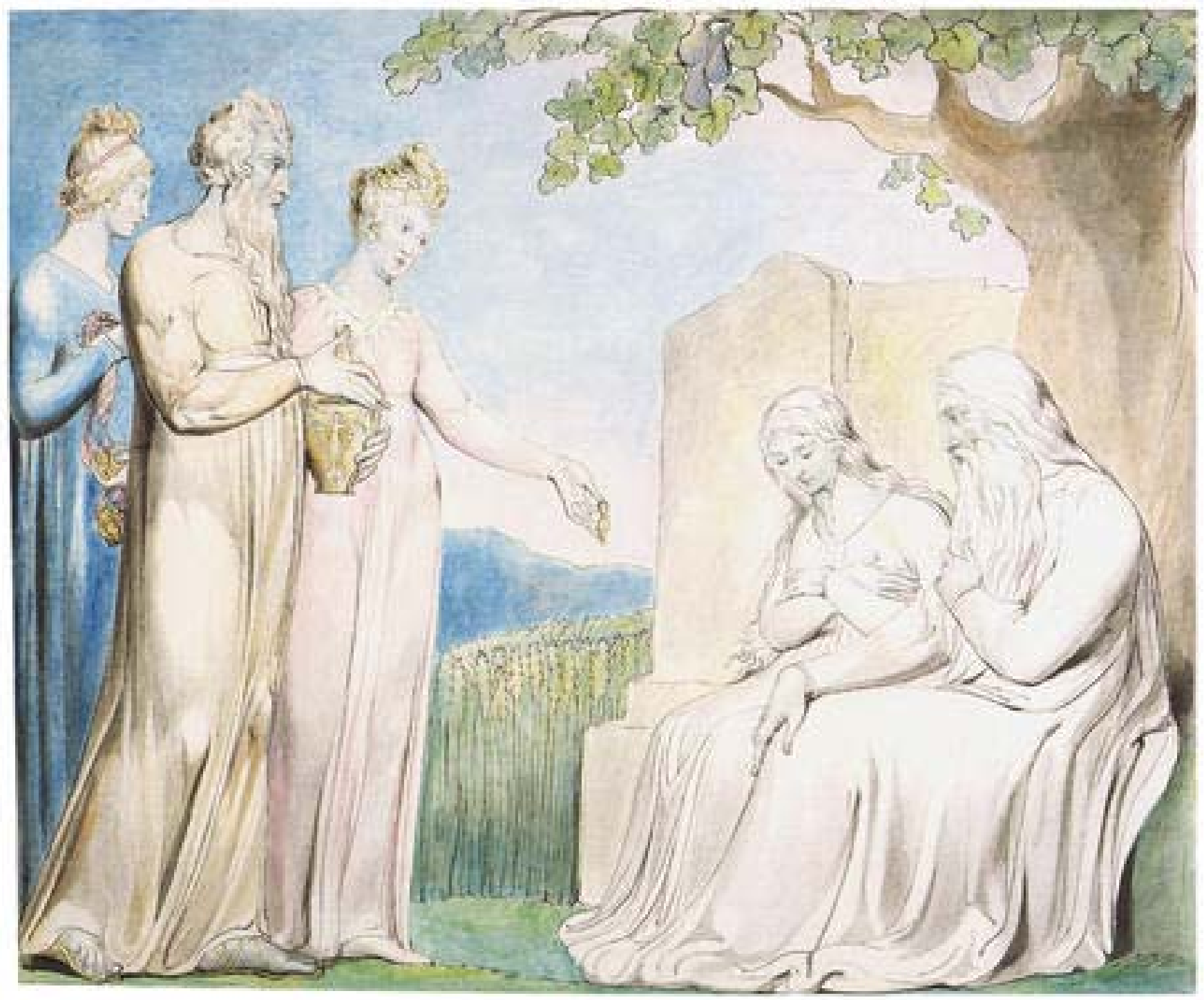

Figure 55

William Blake

The Illustrations of the Book of Job, "Job Accepting Charity" 1825 


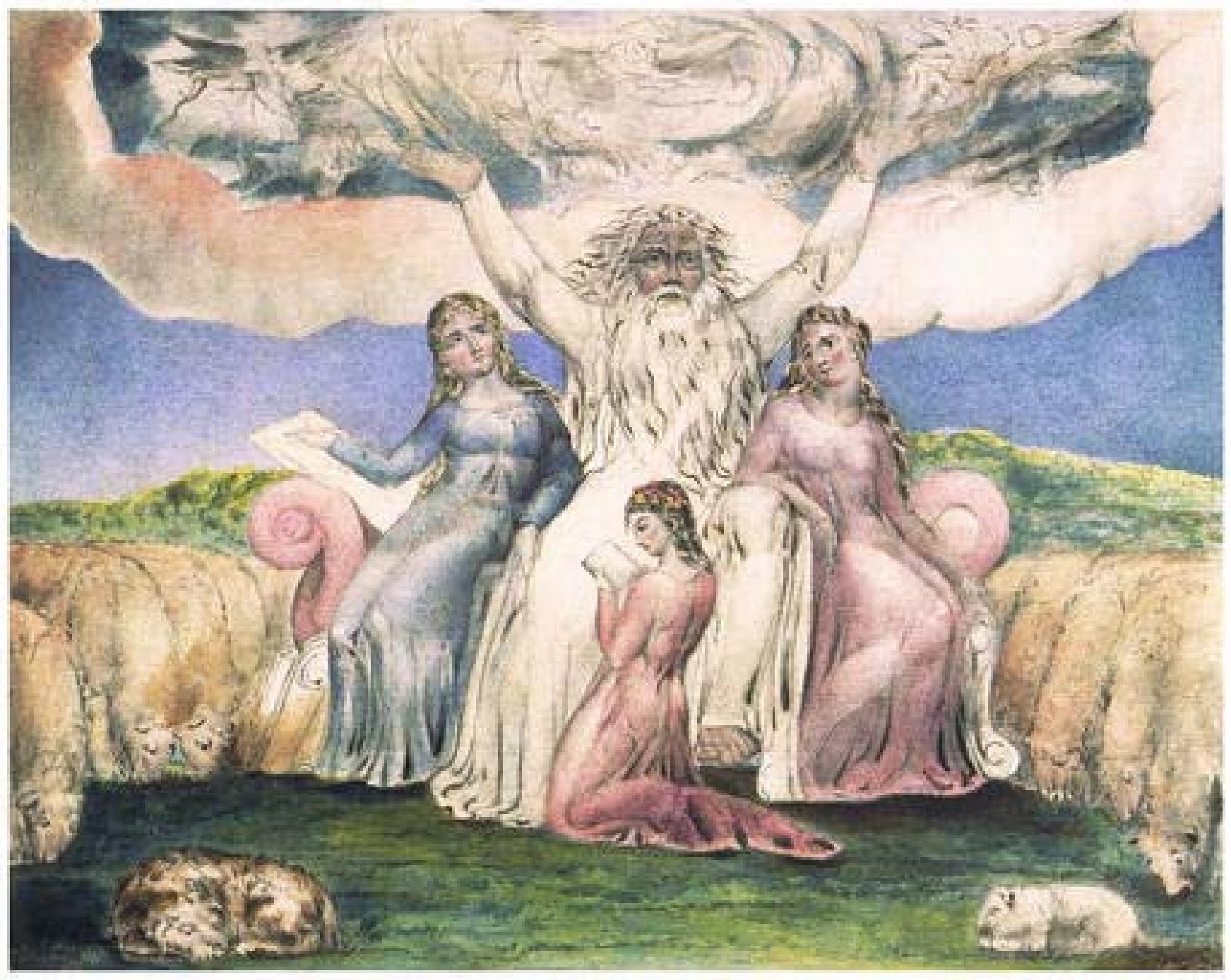

Figure 56

William Blake

The Illustrations of the Book of Job, "Job and his Daughters" 1825 


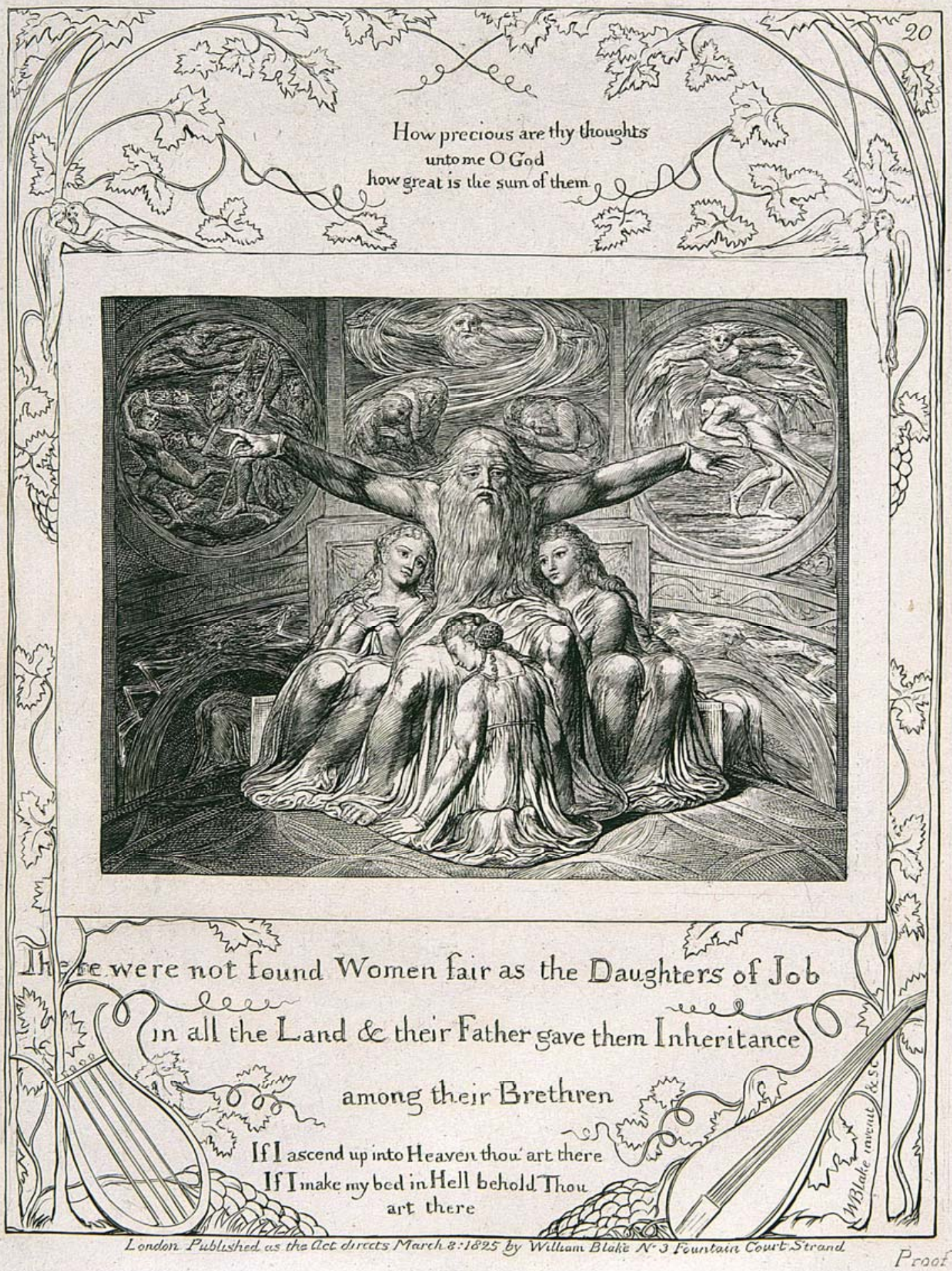

Figure 57

William Blake

The Illustrations of the Book of Job, "Job and his Daughters,"

print, 1825. 


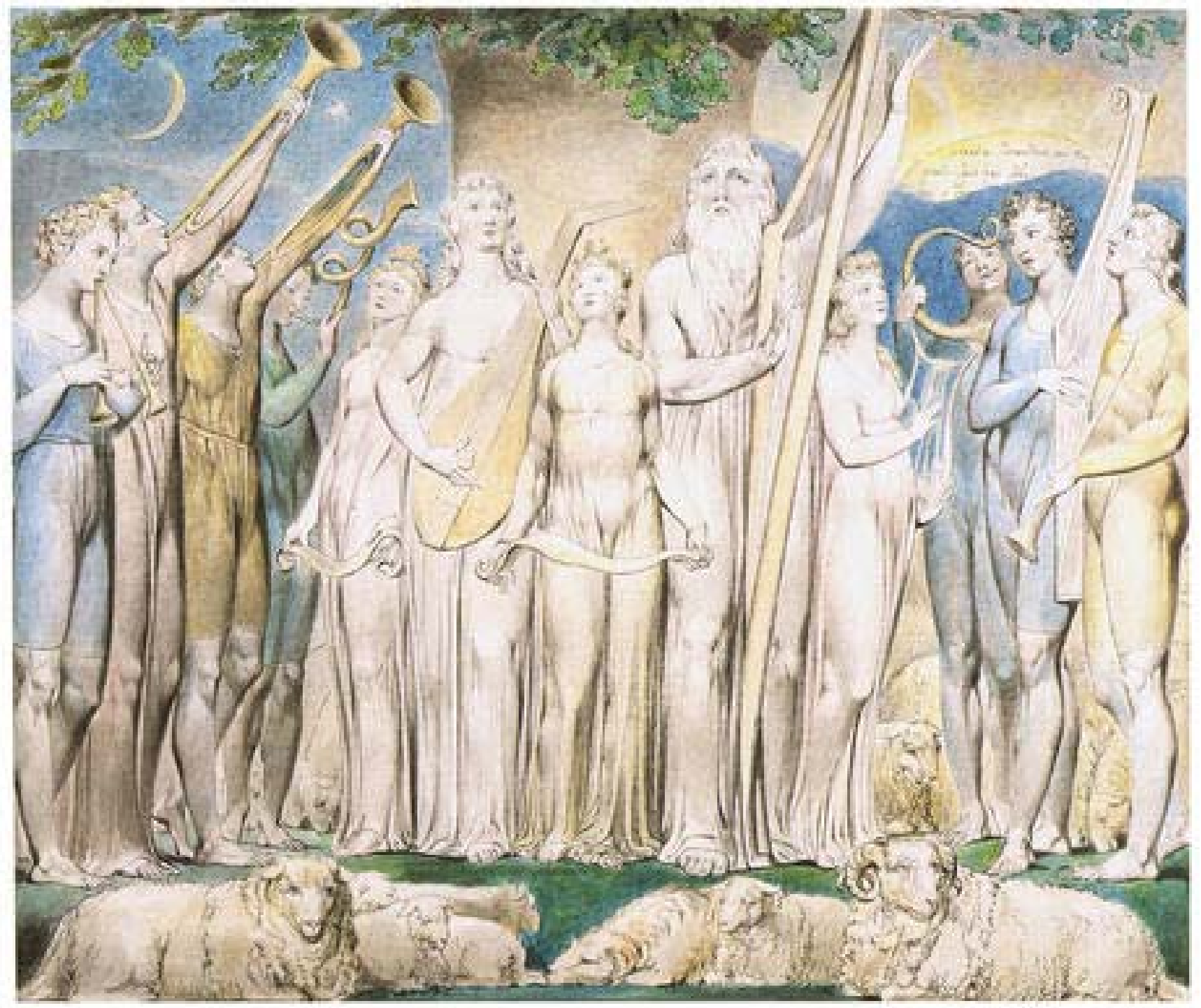

Figure 58

William Blake

The Illustrations of the Book of Job, "Job and his Wife restored to Prosperity" 1825 


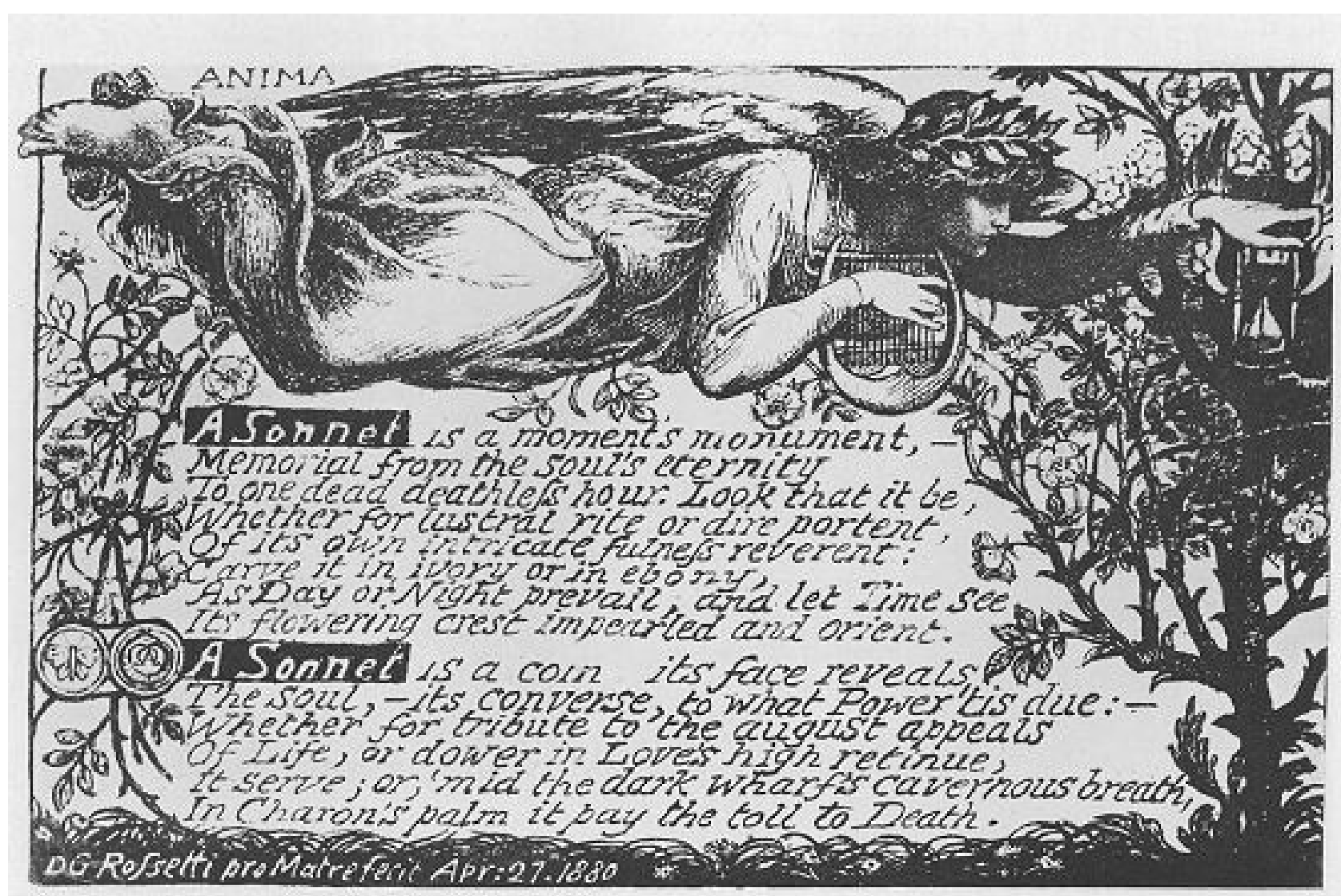

Figure 59

Dante Gabriel Rossetti

'A Sonnet' from the House of Life, "Anima"

1880 